MARCOS ANTONIO DE OLIVEIRA

\title{
MONITORAMENTO DA SATISFAÇÃO DE CLIENTE EM CONTEXTO BUSINESS-TO-BUSINESS: UM SURVEY EM EMPRESAS COM CERTIFICADO ISO 9001-2000 NO ESTADO DE SÃO PAULO
}

\author{
Dissertação apresentada à Escola \\ Politécnica da Universidade de São Paulo \\ para obtenção do Título de Mestre em \\ Engenharia
}

São Paulo 
MARCOS ANTONIO DE OLIVEIRA

\title{
MONITORAMENTO DA SATISFAÇÃO DE CLIENTE EM CONTEXTO BUSINESS-TO-BUSINESS: UM SURVEY EM EMPRESAS COM CERTIFICADO ISO 9001-2000 NO ESTADO DE SÃO PAULO
}

\author{
Dissertação apresentada à Escola \\ Politécnica da Universidade de São Paulo \\ para obtenção do Título de Mestre em \\ Engenharia \\ Área de Concentração: \\ Engenharia de Produção \\ Orientador: \\ Prof. Dr. José Joaquim do Amaral Ferreira
}

São Paulo 


\section{DEDICATÓRIA}

A Você, que comigo sonha meus sonhos, não os de sonhar simplesmente e sim os que são projetos de realizar. Você que coloriu cada momento que estudei, pesquisei, elaborei, escrevi...Sendo presente todo o tempo. 


\section{AGRADECIMENTOS}

Ao meu orientador, Prof. Dr. José Joaquim do Amaral Ferreira, pelas diretrizes seguras, incessante apoio e amizade.

Aos professores do Departamento de Engenharia de Produção pela qualidade dos ensinamentos.

Em especial, ao Prof. Dr. Roberto Gilioli Rotondaro e ao Prof. Dr. Silvio Melhado, por enobrecer o trabalho com suas relevantes participações na banca de qualificação.

Agradeço às mais de 400 empresas que colaboraram com a realização deste trabalho, principalmente aquelas que participaram da pesquisa qualitativa, que gentilmente abriram suas portas à Universidade, colaborando para o desenvolvimento da pesquisa em nosso país.

Agradeço aos meus filhos Marco Antonio, Guilherme e Leonardo pelo apoio, estímulo e motivação. 


\section{RESUMO}

O objetivo deste trabalho é identificar como as empresas que operam no contexto business-to-business realizam o monitoramento da satisfação de seus clientes. O tema é bastante relevante no cenário atual, em que as empresas investem quantias significativas em diversos programas de melhoria e possuem grandes dificuldades para avaliar se tais programas impactam na satisfação de seus clientes e, por consequiência, na sua fidelização. Para tanto, foi realizada uma avaliação de bibliografia disponível, principalmente aquelas provenientes das áreas de marketing e gestão de qualidade. A metodologia adotou elementos de pesquisa quantitativa e qualitativa, mesclando uma pesquisa quantitativa tipo survey com análise de múltiplos casos. $\mathrm{O}$ universo para coleta de dados da pesquisa quantitativa foi empresas com certificado ISO 9000 no estado de São Paulo, extraído da base de dados da Associação Brasileira de Normas Técnicas, partindo-se do pressuposto que essas empresas monitoram a satisfação de seus clientes. A pesquisa qualitativa foi elaborada com base no estudo de múltiplos casos em cinco empresas selecionadas em função de alguns critérios obtidos da avaliação bibliográfica e respostas à pesquisa quantitativa. As conclusões deste estudo são: as empresas certificadas do estado de São Paulo que operam em contexto business-to-business utilizam a pesquisa de satisfação como forma de monitorar a satisfação de seus clientes; com base na revisão bibliográfica e estudos de múltiplos casos, é oferecido um modelo para monitoramento de satisfação de clientes. 


\begin{abstract}
The goal of this work is to identify how companies that act in business-to-business context accomplish the management of their customers satisfaction. This issue is very important in the current scene, in which companies invest expressive sums in several improvement programs and face great difficulties to evaluate the impact of these programs in the customers satisfaction and, in consequence, in their loyalty. In order to carry out this study, we have evaluated the available bibliography, especially that proceeding from the areas of marketing and quality management. The adopted methodology included both elements of quantitative and qualitative research, mixing a quantitative survey and analysis of multiple cases study. The universe for data collection were the companies with ISO 9000 certificate in the state of São Paulo, extracted from the Associação Brasileira de Normas Técnicas data base. This analysis assumed that these companies monitor their customers satisfaction. The qualitative research was elaborated relying on the study of multiple cases in five companies selected in function of some criteria obtained from bibliographical evaluation and the answers to the quantitative survey. The conclusions of this study are: the certified companies in the state of São Paulo that act in business-to-business context use the satisfaciton research as a way of management their customers satisfaction; based on bibliographical revision and study of multiple cases, it is presented a model to monitor the customers satisfaction.
\end{abstract}




\section{SUMÁRIO}

Lista de Tabelas

Lista de Figuras

Lista de Abreviaturas

1 INTRODUÇÃ

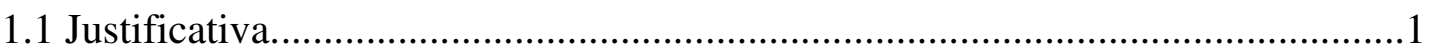

1.2 Estrutura do trabalho.................................................................................4

2 OBJETIVO DA PESQUISA..................................................................................6

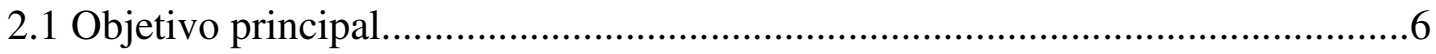

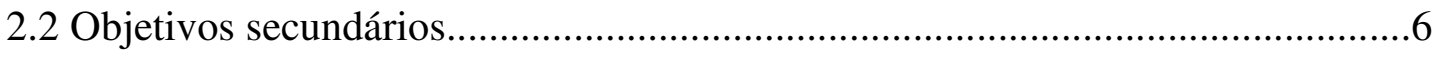

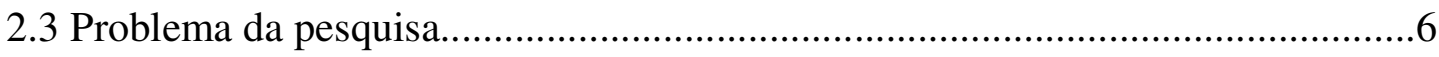

\section{REVISÃO DA LITERATURA......................................................................................8}

3.1 O ambiente de negócios Businnes-to-business .......................................... 10

3.2 A satisfação do cliente e a gestão da qualidade ............................................13

$3.3 \mathrm{O}$ constructo "satisfação de cliente"'.......................................................... 19

3.4 A satisfação de clientes como parte da estratégia das empresas........................31

3.5 Os modelos nacionais de satisfação de clientes...........................................41

3.5.1 O barômetro sueco................................................................4

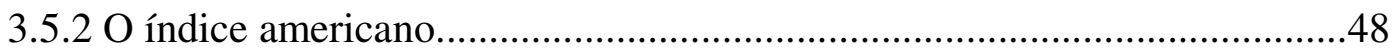


3.5.3 O modelo suíço 50

3.6 A satisfação de cliente e o modelo ISO 9000.....................................................52

3.7 Principais modelos utilizados pelas empresas e citados na literatura..................55

3.7.1 A escala SERVQUAL de Parasuraman, Zeithaml e Berry............................55

3.7.2 A escala Servperf de Cronin e Taylor..........................................................59

3.7.3 O modelo probabilístico de Erto e Vanacore...................................................61

3.7.4 A técnica do incidente crítico de Bob Hayes................................................62

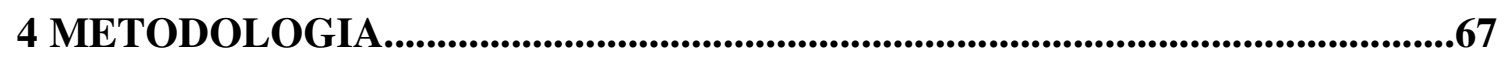

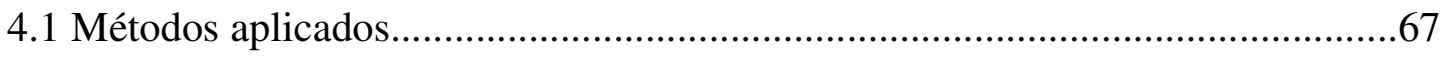

4.2 Escolha do método de pesquisa..........................................................................70

4.2.1 Estratégia de pesquisa quantitativa: survey...............................................71

4.2.1.1 O Software da pesquisa......................................................................72

4.2.1.2 Edição de questionários de pesquisas.....................................................73

4.2.1.3 Cadastro de participantes da pesquisa..................................................74

4.2.1.4 Edição e envio de e-mails de convite, confirmação de participação e lembretes.....................................................................74

4.2.1.5 Gerenciamento de participação e de resultados....................................75

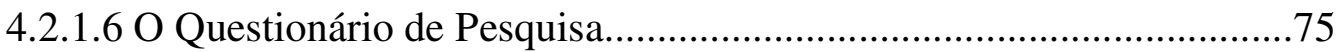

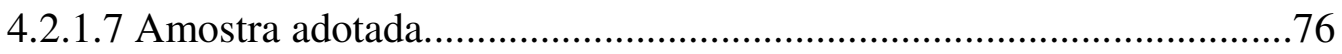

4.2.2 Estratégia de pesquisa qualitativa: estudo de múltiplos casos.....................78

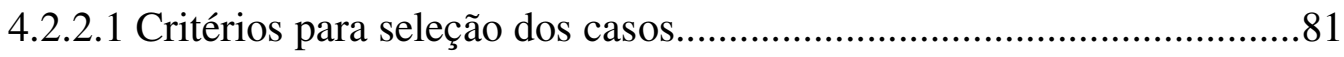

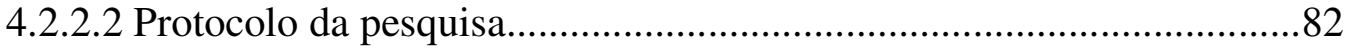




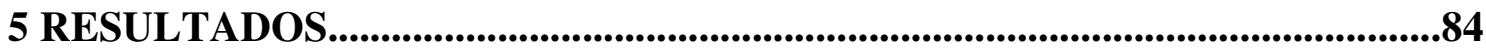

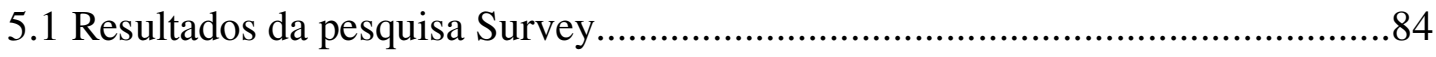

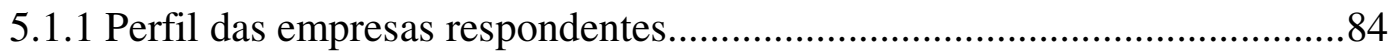

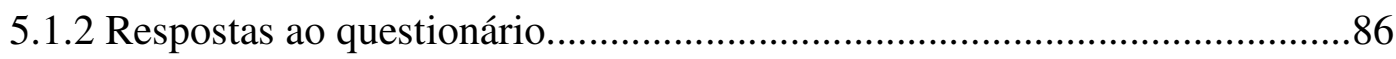

5.2 Resultados dos Estudos de Caso.......................................................................100

5.2.1 Empresa “A"

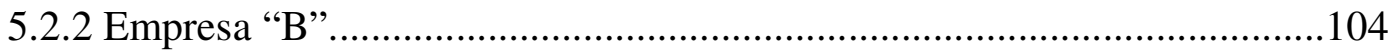

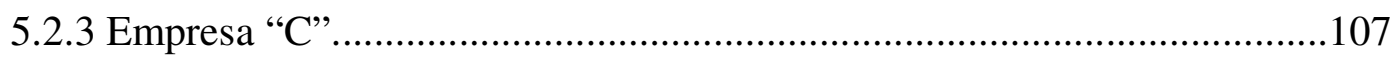

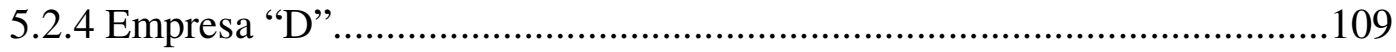

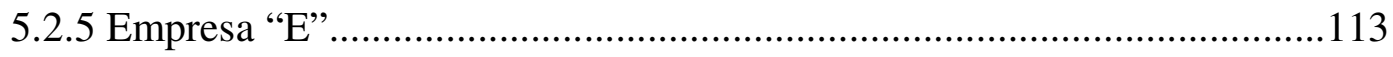

5.2.6 Análise dos casos descritos ..................................................................116

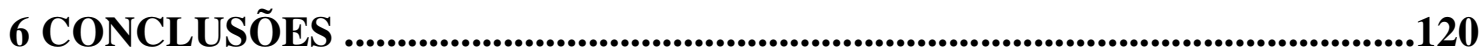

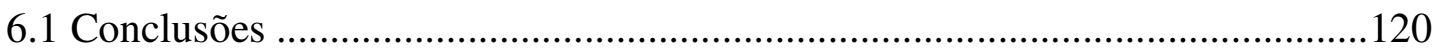

6.2 Limitações e recomendações para futuras pesquisas.........................................125

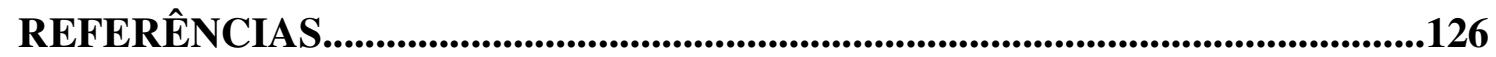

BIBLIOGRAFIA COMPLEMENTAR.........................................................................131

ANEXO - INSTRUMENTO DE PESQUISA SURVEY...........................................133 


\section{LISTA DE TABELAS}

Tabela 1 - Diferenças entre ambientes B2C e B2B..................................................11

Tabela 2 - Principais definições e classificações no modelo de Giese e Cote...............27

Tabela 3 - Marketshare X Satisfação do cliente...........................................................38

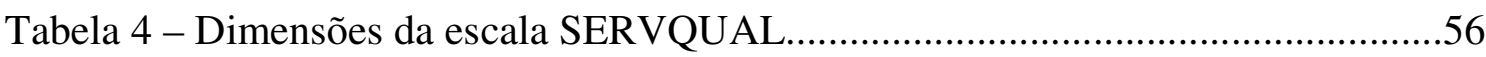

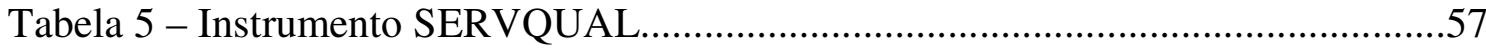

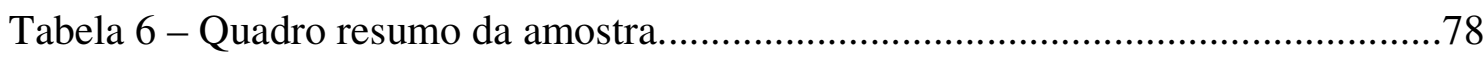

Tabela 7 - Critérios para seleção de casos...............................................................82

Tabela 8 - Áreas de atividades das empresas participantes da pesquisa........................85 


\section{LISTA DE FIGURAS}

Figura 1 - Modelo conceitual de desconfirmação de expectativa.................................. 22

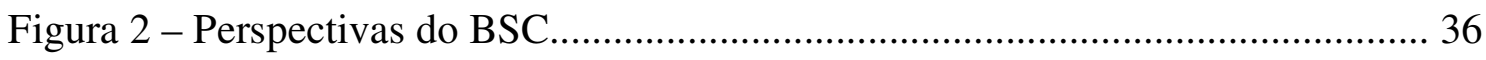

Figura 3 - Modelo de estratégia.............................................................................. 37

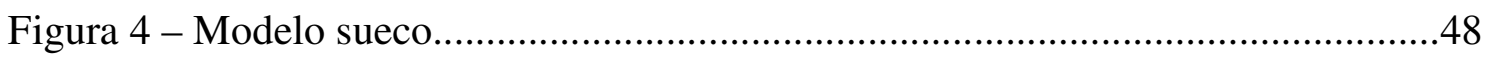

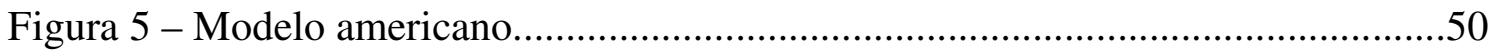

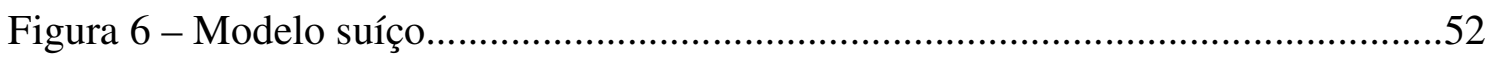

Figura 7 - Modelo de Erto e Vanacore ......................................................................62

Figura 8 - Relacionamento hierárquico entre incidentes críticos, itens de satisfação e

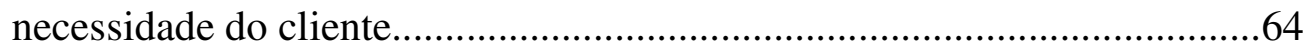

Figura 9 - O método de pesquisa de Bryman............................................................68

Figura 10 - Quantidade de empresas que declararam monitorar a satisfação de seus

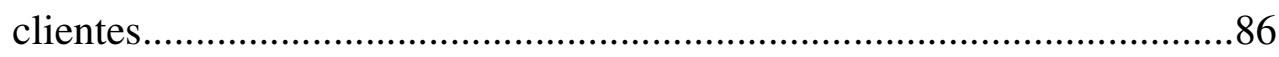

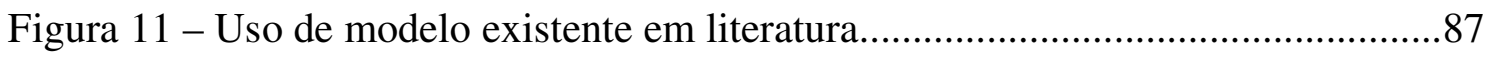

Figura 12 - Departamento responsável pelo monitoramento de

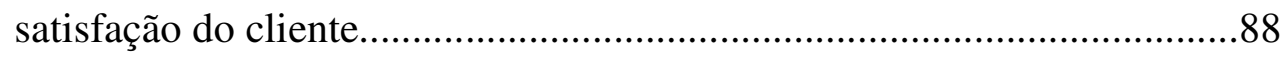

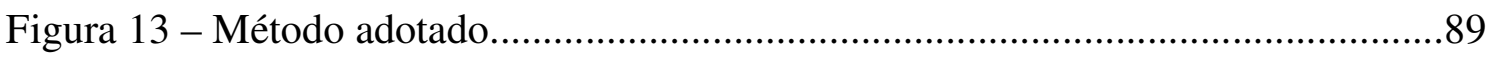

Figura 14 - Freqüência de monitoramento................................................................90

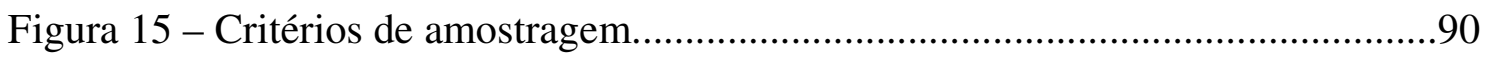

Figura 16 - Tratamento a clientes que deixaram de comprar.......................................91

Figura 17 - Responsabilidade pela elaboração de questionário de pesquisa.................92

Figura 18 - Aspectos contidos nos questionários de pesquisa.......................................92

Figura 19 - Realização de testes de validação do instrumento de pesquisa...................93 
Figura 20 - Endereçamento da pesquisa...................................................................94

Figura 21 - Responsabilidade pela avaliação dos questionários.....................................94

Figura 22 - Apresentação de resultados.....................................................................95

Figura 23 - Existência de índice de satisfação...............................................................96

Figura 24 - Existência de metas para índice de satisfação..............................................96

Figura 25 - Tomada de ações em função de resultados da pesquisa...............................97

Figura 26 - Percentual de questionários normalmente respondidos.............................98

Figura 27 - Ações tomadas para questionários não respondidos...................................99

Figura 28 - Implementação de melhorias no método utilizado....................................100

Figura 29 - Modelo para monitoramento de satisfação de cliente em contexto B2B 


\title{
LISTA DE ABREVIATURAS
}

\author{
ABNT - Associação Brasileira de Normas Técnicas \\ ACSI - American Customer Satisfaction Index \\ ASQ - American Society for Quality \\ B2B - Business to Business \\ B2C - Business to Consumer \\ BSC - Balanced Scorecard \\ CB 25 - Comitê Brasileiro de Qualidade \\ CSB - Consumer Satisfaction Barometer \\ CS/D - Customer Satisfaction/Dissatisfaction \\ INMETRO - Instituto Nacional de Metrologia e Qualidade Industrial \\ ISO - International Organization for Standardization \\ NBR - Norma Brasileira \\ PLS - Partial Least Squares \\ QFD - Quality Function Deployment
}




\section{INTRODUÇÃO}

\subsection{JUSTIFICATIVA}

Tem sido consenso entre especialistas de Administração, Engenharia e Marketing em todo mundo, que empresas podem conseguir cada vez melhores resultados se a satisfação dos clientes for colocada em primeiro lugar.

Partir para ações concretas no sentido de reconhecer e adotar este novo posicionamento tem feito com que muitas empresas implementem ações com o intuito de ouvir seus clientes e consumidores, através de pesquisas aplicadas ou ainda, através de canais abertos para uma comunicação eficaz.

Uma política voltada para o cliente precisa contar, além de um forte compromisso por parte dos níveis decisórios superiores, com informações sobre o cliente no que se refere às suas percepções e comportamentos. Sem este referencial não será possível delinear a estrutura e estabelecer processos adequados que permitam alcançar a produtividade e a competitividade almejada. Uma empresa, ao voltar-se para o cliente, passa a entender e aceitar que a qualidade de seus produtos, serviços e relações é a principal determinante do seu sucesso no mercado. Privilegiar a qualidade é, antes de tudo, admitir a importância dada a este elemento por parte do cliente. 
As empresas devem se preocupar com a identificação das necessidades dos clientes, e se possível, antes mesmo destas serem articuladas por eles. É claro que isto é desejável, mas apresenta sérias dificuldades para sua concretização. No entanto, um objetivo deve ser perseguido e alcançado de modo permanente: o conhecimento do mercado, da sua situação atual e potencial, da percepção do cliente e de seus comportamentos.

A tradução do desempenho das organizações através de indicadores, tanto do ponto de vista de satisfação de clientes quanto dos processos internos é um tema largamente pesquisado na literatura; é o caso, por exemplo, do Balanced Scorecard, com suas quatro dimensões: econômico-financeira, cliente, processo e aprendizagem (Kaplan e Norton, 1996).

A voz do cliente, expressa através de monitoramento de sua satisfação, reclamações e comentários, determina parte das melhorias colocadas em prática no ciclo de planejamento que por sua vez, levam a mudanças nos demais indicadores de desempenho organizacional.

Conforme Hayes (2001), "o conhecimento das percepções dos clientes relacionados aos negócios de uma determinada organização pode aumentar em muito suas possibilidades de tomar melhores decisões empresariais; estas organizações, em conhecendo as necessidades e expectativas de seus clientes serão capazes de determinar se estão atendendo tais necessidades". 
Lambert (1998) afirma que a teoria demonstra que clientes satisfeitos retornarão e comprarão novamente. No entanto, apesar desta teoria ser universalmente aceita, as medições de satisfação do cliente são vistas como custos para a empresa e não como ativos, muito embora, em suas missões e políticas, as mesmas empresas declarem que a satisfação do cliente é seu principal objetivo.

$\mathrm{Na}$ revisão bibliográfica realizada pelo autor, em periódicos da área de marketing e gestão da qualidade, constatou-se a existência de poucos modelos para a realização de monitoramento de satisfação de cliente. Em linhas gerais, o setor de marketing tem produzido maior número de estudos; porém, em sua grande maioria, voltados ao consumidor pessoa-física, que tem necessidades e expectativas muito diferentes do cliente pessoa-jurídica; este último, normalmente, compra utilizando-se de especificações técnicas, não havendo o fenômeno de compra por impulso, tão comum quando se fala de consumidor. Na área de Gestão da Qualidade, os autores insistem na importância da realização do monitoramento da satisfação de clientes, mas não oferecem métodos para a realização desta atividade.

De acordo com Naori e Salimi (2005), um processo business-to-business (B2B), pode ser definido simplesmente como qualquer processo de negócio entre duas empresas diferentemente dos processos business-to-consumer (B2C) que se caracterizam pelos relacionamentos entre empresa e consumidor pessoa-física. Segundo esses autores, estudos sobre business-to-consumer são produzidos há décadas, enquanto somente nos últimos anos, os pesquisadores têm se interessado pelos negócios em ambiente B2B. 
Prieto e Carvalho (2005) afirmam que no segmento B2B a transação de valor econômico é alta e a perda de um único cliente pode resultar em impacto significativamente negativo para as receitas de uma empresa, demandando, portanto, a necessidade de investimentos na construção e manutenção de bons relacionamentos com os clientes.

\subsection{ESTRUTURA DO TRABALHO}

O Capítulo 1 apresenta uma introdução sobre o tema a ser estudado, justificando a relevância do estudo.

O Capítulo 2 apresenta os objetivos e o problema da pesquisa.

O Capítulo 3 contém o referencial teórico, caracterizando o ambiente de negócios B2B e com destaque para uma discussão sobre a visão dos especialistas em Gestão da Qualidade, a importância da satisfação do cliente para a estratégia das organizações, o constructo "satisfação", os modelos nacionais de satisfação, modelos citados na literatura e aplicáveis por organizações e uma breve descrição sobre as normas ISO 9000 e seu requisito de monitoramento de satisfação de clientes.

O Capítulo 4 apresenta os métodos de pesquisa utilizados no presente trabalho, a justificativa de sua utilização e a estrutura dos métodos adotados. Também são apresentados neste capítulo, o software utilizado e o instrumento de coleta de dados. 
O Capítulo 5 contém os resultados da pesquisa quantitativa e qualitativa, expondo as estatísticas descritivas dos métodos adotados pelas empresas para monitoramento de satisfação do cliente, além dos resultados levantados em cinco casos analisados.

O Capítulo 6 apresenta as conclusões e limitações do estudo. A seguir, são apresentadas as referências bibliográficas e, como anexo, o instrumento utilizado tanto na pesquisa survey como nos estudos de caso. 


\section{OBJETIVO DA PESQUISA}

\subsection{OBJETIVO PRINCIPAL}

É objetivo principal deste estudo analisar como as empresas que operam em contexto B2B realizam o monitoramento da satisfação de seus clientes.

\subsection{OBJETIVOS SECUNDÁRIOS}

a) Avaliar modelos de monitoramento de satisfação de clientes propostos na bibliografia consultada quanto à sua capacidade de fornecer informações confiáveis;

b) Propor um modelo para monitoramento da satisfação de clientes de empresas que operam em um contexto Business-to-business (B2B).

\subsection{PROBLEMA DA PESQUISA}

A quase totalidade dos modelos existentes na literatura foi criada para ser aplicada no varejo, visando medir a satisfação do consumidor pessoa-física, não existindo um modelo específico para o contexto B2B.

Destes dados, surgiram os seguintes questionamentos: 
a) Como as empresas que operam no contexto B2B e que em razões de suas certificações são obrigadas a monitorar a satisfação de seus clientes, estão realizando esta atividade?

b) É possível desenvolver um modelo de monitoramento de satisfação específico para o relacionamento $\mathrm{B} 2 \mathrm{~B}$ ?

c) É possível vincular a satisfação com indicadores de desempenho do relacionamento, como por exemplo, quantidade de pedidos entregue com/sem atraso, quantidade reclamações, quantidade de devoluções, etc? 


\section{REVISÃO DA LITERATURA}

De acordo com Anderson e Fornell (2000), a idéia básica de uma economia de mercado é a de que as empresas existem e competem entre si para criar satisfação do cliente; investidores procuram empresas as quais eles esperam que alcancem estes objetivos. Segundo estes autores, não é possível crescer economicamente sem crescimento na satisfação de clientes. Em uma economia de mercado, onde fornecedores competem por clientes, a satisfação do cliente define o significado de atividade econômica, porque o que interessa, em última análise, não é quanto é produzido ou consumido, mas o quanto a economia satisfaz seus consumidores.

Junto com outros objetivos econômicos, tais como nível de emprego e crescimento, a qualidade do que se produz é parte do padrão de vida e a fonte da competitividade nacional. Assim como outros objetivos, a qualidade deve ser submetida a medições sistemáticas e uniformes. Nem as medições de produtividade, nem as medições de evolução de preços podem ser adequadamente calibradas sem se considerar os aspectos de qualidade.

Fundin e Bergman (2003) acreditam que conhecer o que é encantador, o que é satisfação e o que é insatisfação para seus clientes é crítico para o sucesso em um mercado cada vez mais competitivo. A questão é muito intensa nos discursos de qualidade e marketing. Na literatura de desenvolvimento de produtos encontram-se muitos métodos de pesquisa de mercado aplicáveis em planejamento de produto e 
desenvolvimento de processos; informações obtidas de possíveis futuros clientes são largamente utilizadas nos processos de desenvolvimento de produtos através de várias técnicas, como por exemplo, o uso de desdobramento da função da qualidade (QFD). Mas e quanto os clientes atuais dos produtos atuais? Espera-se que eles permaneçam fiéis. Uma regra existente é a de que custa cinco vezes mais ganhar um novo cliente do que manter um antigo (Dutka, apud Fundin e Bergman, 2003).

A mesma visão é compartilhada por Hackl e Westlund (2000) que pregam que existem duas razões básicas para medir e modelar a satisfação de clientes:

a) Prover Stakeholders com informações confiáveis sobre valores e perspectivas de seus investimentos;

b) prover a gerência com informações que permitem boas decisões em suas atitudes de mercado.

Segundo os autores, os profissionais de contabilidade estão tentando desenvolver sistemas com o objetivo de incluir ativos intangíveis. Devido a vários problemas, como a dificuldade em evitar efeitos de overlapping entre vários elementos dos modelos e dificuldades de medição, a praticidade de tais modelos torna-se limitada. Em respeito sobre qual estrutura conceitual ou prática é fixada para descrever ativos intangíveis de uma empresa, o valor de tais ativos é, em sua grande maioria, materializado através de clientes e mercados. Pode-se argumentar que todo esforço 
para descrever melhor e expor valores de ativos intangíveis deveria se concentrar em medir os ativos "Clientes".

Finalmente, em níveis macro-econômicos, torna-se muito difícil conduzir políticas econômicas sem medições precisas e compreensíveis. A satisfação de clientes tem um considerável valor como complemento às medidas tradicionais de produtividade e consumo. Assim, países desenvolvidos como Estados Unidos e Suécia já possuem, há algum tempo, seus Índices Nacionais de Satisfação de Consumidores.

\subsection{O AMBIENTE DE NEGÓCIOS BUSINNES-TO-BUSINESS}

De acordo com Prieto e Carvalho (2005), o mercado B2B é menor em número de clientes se comparado ao mercado de venda direta ao consumidor (B2C). No entanto, é composto por empresas cujos portes podem variar de pequeno a grande, e em função disto, o valor econômico das transações é alto. Assim, o valor econômico das transações de um único cliente ao longo de sua existência pode ser muito expressivo. A perda de um cliente pode, portanto, ter um impacto negativo para o faturamento da empresa, tornando-se importante a ênfase na manutenção dos clientes existentes. Prieto e Carvalho (2005) salientam que o maior interesse das empresas que atuam neste segmento é construir relacionamentos duradouros, baseados na confiança e nos

interesses mútuos e, ainda, entregar produtos e serviços de alto valor, mantendo a satisfação dos clientes e, como conseqüência, sua fidelidade. 
Stone e Jacobs apud Prieto e Carvalho (2005) estabeleceram as principais diferenças entre os negócios em ambiente B2C e B2B, mostradas na tabela 1

Tabela 1 - Diferenças entre ambientes B2C e B2B Fonte: Carvalho (2005)

\begin{tabular}{|ll|}
\hline \multicolumn{1}{|c|}{ Ambiente B2C } & \multicolumn{1}{c|}{ Ambiente B2B } \\
\hline Compram para benefício próprio & Compram para benefício da organização \\
\hline $\begin{array}{l}\text { Decisões de compras não envolvem tanto } \\
\text { outras pessoas }\end{array}$ & $\begin{array}{l}\text { Freqüentemente as decisões envolvem } \\
\text { várias pessoas }\end{array}$ \\
\hline Grupos de compradores individuais & Múltiplos grupos de compradores \\
\hline Processo informal de compras & Processo formal e informal de compras \\
\hline Baseado nas transações & Baseado no relacionamento \\
\hline $\begin{array}{l}\text { Tamanho médio relativamente pequeno } \\
\text { de compras }\end{array}$ & $\begin{array}{l}\text { Tamanho médio de compras tende a ser } \\
\text { grande }\end{array}$ \\
\hline Lifetime value relativamente baixo & Lifetime value pode ser muito amplo \\
\hline Facilidade de chegar até as pessoas & Dificuldade de chegar às pessoas \\
\hline
\end{tabular}

Outra característica relevante do mercado B2B é o fato do processo de venda ser mais complexo, exigindo negociações com múltiplos grupos e a necessidade de se manter uma estrutura para gerenciar as fases desta negociação. Assim, mais uma vez, torna-se importante investir na construção e manutenção de um relacionamento com os atores que influenciam ou dirigem os processos de compra.

Segundo Walker e Neeley (2004), a compra no contexto B2B é tipicamente apresentada com um processo multi-passos, iniciando-se com a necessidade de compra e finalizando com a decisão.

Em geral, os modelos de decisão de compra consistem das seguintes etapas: 
a) Reconhecimento da necessidade;

b) Determinação de especificações para o produto ou serviço;

c) Procura de fornecedores qualificados;

d) Solicitação e avaliação de propostas;

e) Emissão de pedidos de compra ou contratos;

f) Avaliação do desempenho do produto ou serviço adquirido.

Os compradores executam as duas primeiras etapas internamente e geralmente estas etapas não são abertas aos possíveis fornecedores. As duas próximas etapas envolvem a consulta ao mercado e compreendem as atividades de pré-compra, quando os compradores buscam as melhores alternativas para suas necessidades e que melhor vão atender suas especificações.

A transação de compra é descrita como um passo único. Nesta etapa o cliente já se decidiu sobre o produto ou serviço e seu fornecedor. Suas expectativas estão concentradas em termos de como o fornecedor processa os pedidos e contratos, cumprimento de prazos e atendimento às especificações. A fase de compra envolve tanto a primeira compra como também as posteriores.

O estágio de pós-compra envolve todos os aspectos relacionados à entrega, utilização do produto ou serviço e eventual assistência técnica. 


\subsection{A SATISFAÇÃO DO CLIENTE E A GESTÃO DA QUALIDADE}

Deming (1990) enfoca a qualidade principalmente pelo aspecto da estatística, interessando-se pelos problemas de variabilidade e suas causas. Técnicas estatísticas, tais como gráficos de controle de processo, são propostos por permitirem a distinção entre "causas especiais e comuns" - as primeiras atribuídas a indivíduos ou máquinas, e as outras de responsabilidade gerencial, como falhas das matérias-primas que tomam parte em várias operações. A estatística confere o rigor da análise necessária à solução de problemas da qualidade.

Deming (1990) estende-se enfatizando uma abordagem sistemática para solução de problemas da qualidade, conhecida como Ciclo de Deming ou como o PDCA- Plan, Do, Check, Action. Estimula também a alta gerência a se envolver nos programas de melhoria da qualidade. Deming assim se expressa: "(...) a qualidade desejada começa com a intenção, que é determinada pela direção. A intenção tem de ser traduzida para planos, especificações, testes, numa tentativa de oferecer ao cliente a qualidade pretendida, e tudo isso é da área de responsabilidade da administração". O comprometimento dos níveis estratégicos é fundamental para a produção da qualidade seja de produtos ou serviços.

Deming (1990) também reconhece a amplitude do conceito de qualidade que "só pode ser definida em termos de quem a avalia". "A dificuldade de se definir a qualidade está na conversão das necessidades futuras do usuário em características mensuráveis, de 
forma que o produto possa ser projetado e modificado para dar satisfação por um preço que o usuário pague".

A ênfase de que a qualidade para ser produzida deve ser medida fornece bases objetivas de sua análise desde o projeto de produtos ou serviços. E, neste propósito, a qualidade deve ser medida através da interação de três participantes:

a) O produto em si;

b) O usuário e como ele usa o produto, como instala, como cuida dele;

c) As instruções de uso, treinamento do cliente e treinamento da assistência técnica, os serviços disponíveis para reparos, a disponibilidade das peças.

Em resumo, o produto, o cliente e atividades de pós-venda são os elementos relevantes no projeto de qualidade de produtos e serviços.

Feigenbaum (1991) traz uma abordagem sistêmica ou total da qualidade, requerendo o envolvimento de todas as funções no processo da qualidade, e não simplesmente a fabricação. A qualidade é vista como a que os clientes exigem, retratada através das especificações em todas as fases, com qualidade de processos compatível com tais especificações. "Qualidade quer dizer o melhor para certas condições do cliente".

Um ponto que também enfatiza é a questão da necessidade de uma assistência econômica ao usuário, através de um esforço de diferentes áreas da empresa. Segundo Feigenbaum (1991), seria um "sistema voltado para propiciar a satisfação ao 
consumidor, gerando produtos, através de um sistema produtivo, de forma econômica de assistência ao usuário, estruturando-se de tal modo que os diferentes grupos integrantes da organização contribuam para o esforço do desenvolvimento, manutenção e melhoria da qualidade em forma global".

A abordagem de Juran (1990) possui um forte ingrediente gerencial e focaliza planejamento, fluxo organizacional, responsabilidade gerencial para qualidade e a necessidade de estabelecer metas e objetivos para a melhoria.

Juran (1990) aceita a existência de várias definições para a qualidade em sua obra. "Um dos significados da qualidade é desempenho do produto". Este resulta das características do produto que levam à satisfação, e interferem na decisão de compra; elas afetam as vendas e neste caso qualidade mais alta geralmente custa mais caro.

"Outro significado de qualidade é ausência de deficiências". Estas levam à insatisfação e que leva os clientes a reclamarem. "Satisfação com o produto e insatisfação com o produto não são opostos". Pode-se estar satisfeito com algumas características, mas existe a insatisfação com outras, uma expectativa de melhoria ou inclusão de atributos. Deficiências do produto afetam os custos, por falhas no uso e necessidade de garantia, repetição de trabalhos e desperdício.

A conveniência de juntar estas duas "espécies de qualidade" levou à conhecida definição simples de qualidade: adequação ao uso. Juran (1992) evoluiu no seu 
enfoque para o conceito de satisfação para maximização das aspirações do usuário, pela avaliação da qualidade como "adequação ao uso". Reconhece-se, contudo, que a visão é sempre de que a qualidade deve ser conceituada a partir do usuário.

Ishikawa (1993) nos proporciona uma visão ampla de qualidade e considera importante a interpretação de seu conceito. Sua visão praticamente abrange as de todos os predecessores, acrescentando apenas a importância da percepção rápida por parte das empresas às exigências crescentes de mercado.

O termo qualidade interpretado de forma mais ampla significa "qualidade de trabalho, qualidade de serviço, qualidade de informação, qualidade de processo, qualidade de divisão, qualidade de pessoal, incluindo operários, engenheiros, gerentes e executivos, qualidade de sistema, qualidade de empresa, qualidade de objetivos etc. Nosso enfoque básico é controlar a qualidade em todas as suas manifestações".

O sistema de qualidade evidencia-se desde o desenvolvimento e projeto de novos produtos ou serviços, sendo aperfeiçoado através da estrutura da empresa. É reforçado para uma malha de relações que cobre as funções da qualidade, de modo a permitir ao cliente perceber que a qualidade esperada e prometida está garantida.

Segundo Garvin (1992), Qualidade é tanto um problema como uma oportunidade para as empresas. O autor conduz sua análise do conceito pela evolução da qualidade dentro das empresas, onde de uma restrita disciplina técnica com o objetivo de detectar 
problemas de fabricação, passou para todos os estágios desde o projeto até a comercialização.

O significado competitivo da qualidade conduz sua definição a partir do ponto de vista do cliente, ligada com lucratividade tanto da comercialização como do custo, necessitada de melhoria contínua e níveis que excedessem os atingidos por concorrentes, estruturada num processo de planejamento estratégico, obtido através de amplo comprometimento de toda organização liderado pela alta gerência. Para implementar esta nova abordagem competitiva da qualidade, as empresas necessitam em primeiro lugar entender o que qualidade significa para seus clientes e falta-lhes com frequiência o vocabulário necessário. Com este objetivo, revendo a literatura, Garvin (1992) verifica que são várias as perspectivas das definições para a qualidade "num esquema de análise diferente e empregando sua própria terminologia", conforme procedam da Filosofia, Economia, Marketing ou Engenharia de Produção; e, ao "mesmo tempo, existem, claramente, muitos temas comuns". Assim, ele identifica cinco abordagens principais para a definição da qualidade, descritas abaixo:

a) Abordagem transcendente: a Qualidade é a excelência inata - são os conceitos que tratam de qualidade como um estado efêmero ou excelência inata, universalmente reconhecida. Neste caso não pode ser medida precisamente e o seu reconhecimento ocorre pela experiência; 
b) Abordagem baseada no produto (na oferta): a Qualidade é a medida da quantidade de alguns atributos possuídos pelo produto - nestes conceitos a qualidade é mensurável e alcançada quando se obtém mais um ingrediente do produto. Em geral, originam da Economia, enfocando "durabilidade" e que alta qualidade ocorre com alto custo;

c) Abordagem baseada no uso (no usuário): a Qualidade é o reflexo das preferências do cliente - são definições que estabelecem que a qualidade está apenas nos olhos do usuário e integra fatores subjetivos definidos na satisfação do consumidor. A avaliação do usuário em relação às especificações são os únicos padrões próprios à qualidade;

d) Abordagem baseada na fabricação: a Qualidade é a conformidade com especificações - qualidade é atender aos requisitos e melhorias de qualidade consideradas como redução do número de desvios, representam redução de custos. É quase que oposta à abordagem baseada no usuário;

e) Abordagem baseada no valor: a Qualidade é o desempenho ou conformidade a um preço aceitável - são conceitos que reúnem necessidades do consumidor às exigências de fabricação definindo qualidade em termos de custos e preços. Produto de alta qualidade oferece desempenho a um preço aceitável; ele tem valor. 
Garvin (1992) estende-se nestas abordagens, apresentando a qualidade nas seguintes dimensões: desempenho, características, confiabilidade, conformidade, durabilidade, atendimento e qualidade percebida.

Observa-se que qualquer que seja o enfoque apresentado anteriormente, o cliente/consumidor com suas necessidades, percepções, satisfações e insatisfações está sempre presente, com também está presente em todos eles a necessidade de medição da qualidade através de suas dimensões.

\subsection{O CONSTRUCTO “SATISFAÇÃO DE CLIENTE”}

Kotler (1998) afirma que, de modo geral, um cliente procura entre os produtos e serviços oferecidos, aquele que lhe oferece o maior valor. Nos limites de seus esforços, de sua informação, de sua mobilidade e de sua renda, procura maximizar esse valor. Quando o produto adquirido entrega efetivamente o valor que o cliente procurava, nasce a satisfação. Assim, para o autor, satisfação é o sentimento de prazer resultante da comparação do desempenho esperado pelo produto (ou serviço) em relação às suas expectativas. Para Kotler (1998), satisfação é função do desempenho percebido e das expectativas. Se o desempenho atender às expectativas, o cliente está satisfeito e se excedê-las estará altamente satisfeito ou encantado. Ainda segundo Kotler (1998), o cliente cria suas expectativas a partir de experiências passadas, contatos com outros clientes e das promessas dos vendedores e da propaganda. Se as promessas veiculadas forem desproporcionais, a decepção é provável. 
A abordagem de Kotler (1998) está em conformidade com o paradigma da desconfirmação, conceito atualmente mais aceito entre os acadêmicos da área de Marketing. Os defensores deste paradigma acreditam nos seguintes fundamentos:

a) A satisfação/insatisfação (CS/D - Customer satisfaction/dissatisfaction) pode ser definida como a resposta do cliente à avaliação da diferença percebida entre a sua expectativa e a performance real após o consumo do produto ou serviço (DAY, 1984);

b) a CS/D é influenciada por um padrão de comparação de pré-experiência (Bearden e Teel, 1983; Cardozo, 1965; Day, 1984; Liechty e Churchill, 1979, Miller, 1977; Oliver, 1977, Cadotte, Woodruff e Jenkis, 1987) e é a extensão na qual este padrão de pré-experiência é desconfirmado.

Oliver (1981) resume o pensamento sobre satisfação dentro do paradigma da desconfirmação com a seguinte definição:

"Satisfação é um estado psicológico resultante quando a emoção da expectativa desconfirmada é combinada com os sentimentos prévios do consumidor acerca da experiência de consumo".

Oliver (1981) ainda resume a natureza da transação específica da satisfação e a diferença de qualidade percebida, como segue:

"Qualidade percebida é uma orientação duradoura do cliente por um produto, empresa ou processo, enquanto que satisfação é a reação emocional que se segue a uma 
desconfirmação, a qual age sobre o nível de atitude básico e referente a um consumo específico. Atitude é, portanto, medida em termos mais gerais ao produto ou empresa e menos situacionalmente orientada".

Para o autor, qualidade percebida é um julgamento global (ou atitude) relativo à superioridade do produto ou serviço, enquanto que a satisfação é relacionada a uma transação específica. Esta visão é compartilhada pelos autores Parasuraman, Zeitthaml e Berry (1985), criadores da escala SERVQUAL, além de Grohroos (1982), Churchill e Suprenant (1982) e muitos outros.

A Figura 1 mostra os componentes essenciais do processo de Satisfação, de acordo com o paradigma da desconfirmação. Em um determinado tempo t, é feita uma escolha por um determinado produto ou serviço. Em algum tempo t+1, o produto ou serviço é consumido e o consumidor avalia a experiência. A avaliação envolve comparação da performance percebida com algum padrão de comparação e três outputs são possíveis:

a) Ocorre a confirmação da expectativa e o sentimento do cliente é neutro;

b) Ocorre uma desconfirmação positiva: a performance excede a expectativa e o cliente fica satisfeito;

c) Ocorre uma desconfirmação negativa: a performance é inferior às expectativas e o cliente fica insatisfeito. 


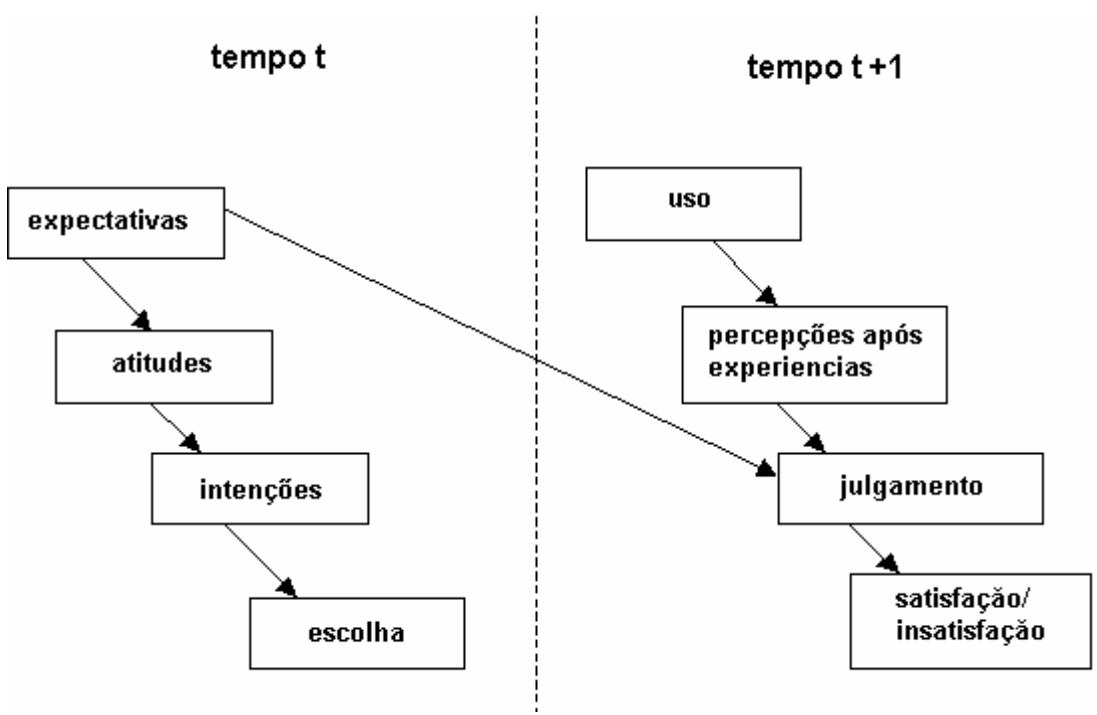

Figura 1 - Modelo Conceitual de Desconfirmação de Expectativa

Fonte: Cadotte, Woodruff e Jenkins (1987)

Neste paradigma, entretanto, existem algumas ambigüidades: apesar de Churchill e Suprenant (1982) afirmarem que performance percebida é determinante da CS/D, a maioria dos modelos não incorpora um link direto deste constructo para CS/D. Além disso, pesquisadores não convergem sobre o exato conceito do padrão de comparação.

Três abordagens para conceituar os padrões de comparação de pré-experiência são normalmente sugeridas na literatura.

A performance eqüitativa, da teoria eqüitativa de Adams (1963), representa um padrão normativo para performance baseado em relações implícitas entre os custos/investimentos individuais e recompensas. Representa o nível de performance que o consumidor espera receber, dado um certo conjunto de custos (Liechty e 
Churchill, 1979; Miller, 1977). Assim, o constructo é afetado pelo preço pago, esforço investido e experiências prévias com o produto.

A segunda abordagem é a da performance ideal de produto, a qual deriva do modelo de ponto ideal de preferências e escolha de Holbrook (1984) e representa a performance ótima que um consumidor espera obter. Reflete o que a performance "Pode Ser". É baseada em experiências prévias, aprendizados originados de propaganda e comunicação boca a boca.

Outra abordagem é a da performance esperada, derivada da teoria da expectativa de Tolman (Tolman apud Churchill e Suprenant, 1982), representa a performance mais provável. O constructo reflete a performance provável e é afetado pela performance média de produtos e efeitos de propaganda.

Como uma abordagem alternativa, a desconfirmação subjetiva (Churchill e Suprenant, 1982; Oliver, 1980) representa um constructo psicológico distinto, fechado em uma avaliação subjetiva sobre diferenças entre performance de produtos e padrão de comparação; isto é, a desconfirmação subjetiva encerra o conjunto de processos psicológicos que podem mediar as discrepâncias na performance percebida do produto.

Há muitos críticos deste paradigma, como LaTour e Peat (1979), que argumentam que sob certas condições o constructo "desconfirmação" sozinho pode falhar para explicar 
adequadamente a formação CS/D. Por exemplo, consumidores forçados a comprar uma marca inferior (se, por exemplo, sua marca preferencial não está disponível) podem, não necessariamente, experimentar desconfirmação de uma comparação com padrão pré-existente, porém, podem estar insatisfeitos devido à sua performance inferior. Os mesmos autores afirmam que testadores de novas marcas que experimentam desconfirmação desfavorável a um padrão elevado de pré-experiência podem ainda estar satisfeitos com a marca se ela possui mais atributos desejados que as marcas concorrentes.

As pesquisas de Cronin e Taylor (1992) revelaram que a satisfação age como uma função intermediária entre percepções de qualidade anteriores, contribuindo para a percepção atual do cliente sobre a qualidade de produtos e serviços. Estes autores demonstraram que a satisfação tem uma forte correlação com a intenção de compra e que a qualidade percebida tem uma correlação inferior; afirmam que clientes não necessariamente compram os produtos e serviços de alta qualidade percebida, mas aqueles que proporcionam maior satisfação. Segundo estes autores, características como preço, conveniência e disponibilidade podem melhorar a satisfação não exercendo influência sobre a qualidade percebida.

Anderson e Sullivan (1993) realizaram uma ampla pesquisa com clientes de empresas suecas, questionando os antecedentes e conseqüências da satisfação de clientes e concluíram que a expectativa não influencia diretamente o constructo "satisfação". 
Além disso, os autores concluíram que o desempenho percebido do produto ou serviço é uma função da satisfação.

São poucos os estudos sobre satisfação de empresas. Até o presente momento, a grande maioria dos estudos acadêmicos tem concentrado esforços na determinação da satisfação de usuários finais de produtos e serviços. Segundo Schellhase, Hardock e Ohlwein (1999), a satisfação de empresas é resultado de um processo complexo de informações e aspectos chave do desempenho das relações cliente-fornecedor. As expectativas do cliente proporcionam o benchmarking para a avaliação da situação percebida. Se eles estão em linha com a percepção da situação real, as partes envolvidas tomam tal fato como uma confirmação do objetivo. Se as expectativas relacionadas ao desempenho dos componentes considerados importantes são exercidas, a satisfação é experimentada.

Giese e Cote (2000) propõem um interessante modelo conceitual para satisfação de clientes. Segundo os autores, a literatura contém diferenças significativas para as definições do constructo "satisfação", porém todas elas têm fatores comuns, sendo estes:

a) A satisfação é uma resposta emocional ou cognitiva;

b) A resposta está no domínio de um determinado foco (expectativa, produto, experiência de consumo, etc), e;

c) a resposta ocorre em um determinado tempo (após o consumo, após a compra, após a escolha, etc) e tem uma determinada duração. 
A resposta varia de intensidade, dependendo da situação. Termos como "amável", "excitante", "surpresa prazerosa", "indiferente", "frustrado", etc., revelam a gama de intensidade. O foco identifica o objeto da satisfação do consumidor; usualmente ele compara o desempenho com algum tipo de padrão, este último podendo variar de muito específico a muito genérico, existindo freqüentemente muitos focos nos quais os padrões são incluídos como “decisão de compra”, "experiência com o uso do produto’, etc. A determinação de um foco apropriado varia de contexto para contexto, dependendo do interesse do pesquisador. Entretanto, argumentam os autores, sem um foco claramente definido, qualquer definição para o constructo "satisfação" será pobre, pois sua interpretação poderá variar de pessoa para pessoa. Finalmente, o tempo de resposta é o terceiro componente do modelo. É geralmente aceito que a satisfação é um fenômeno pós-compra, porém ela também pode ocorrer em momentos de decisão de compra e mesmo na ausência da compra. Assim, determinar em que tempo a satisfação deverá ser medida é essencial para a análise dos resultados. Adicionalmente à duração da satisfação deve ser considerada quando do planejamento de pesquisa de satisfação.

Giese e Cote (2000) ainda discutem sobre a natureza da insatisfação, comentando que para alguns autores a insatisfação é considerada o oposto bi-polar da satisfação, e para outros se trata de um constructo com dimensões próprias, argumentando que consumidores podem estar satisfeitos com alguns aspectos de um produto ou serviço e insatisfeitos com outros. 
Giese e Cote (2000) analisaram as principais definições de satisfação propostas por diversos autores nos últimos 30 anos e as classificaram de acordo com seu modelo. A tabela 2 mostra essa classificação.

Tabela 2 - Principais definições e classificações no modelo de Giese e Cote (2000)

\begin{tabular}{|c|c|c|c|c|}
\hline Fonte & Definição conceitual & Resposta & Foco & Tempo \\
\hline $\begin{array}{l}\text { Oliver } \\
(1997)\end{array}$ & $\begin{array}{l}\text { A resposta plena do } \\
\text { consumidor. O } \\
\text { julgamento de que as } \\
\text { características de um } \\
\text { produto ou serviço } \\
\text { fornecem um nível de } \\
\text { prazer relacionado ao } \\
\text { seu consumo }\end{array}$ & $\begin{array}{l}\text { Resposta } \\
\text { geral/julgamento }\end{array}$ & $\begin{array}{l}\text { Produto ou } \\
\text { Serviço }\end{array}$ & $\begin{array}{l}\text { Durante o } \\
\text { consumo }\end{array}$ \\
\hline $\begin{array}{l}\text { Halstead, } \\
\text { Hartman e } \\
\text { Schmidt } \\
\text { (1994) }\end{array}$ & $\begin{array}{l}\text { Uma resposta afetiva a } \\
\text { uma transação específica } \\
\text { resultante de uma } \\
\text { comparação da } \\
\text { performance do produto } \\
\text { com algum padrão pré- } \\
\text { compra }\end{array}$ & Resposta afetiva & $\begin{array}{l}\text { Performance de } \\
\text { produto } \\
\text { comparado com } \\
\text { algum padrão } \\
\text { pré-compra }\end{array}$ & $\begin{array}{l}\text { Durante ou } \\
\text { após o } \\
\text { consumo }\end{array}$ \\
\hline $\begin{array}{l}\text { Mano e } \\
\text { Oliver } \\
(1993)\end{array}$ & $\begin{array}{l}\text { Satisfação com o } \\
\text { produto é uma atitude, } \\
\text { um julgamento pós- } \\
\text { consumo, com uma } \\
\text { variação contínua }\end{array}$ & $\begin{array}{l}\text { Atitude- } \\
\text { julgamento com } \\
\text { variação } \\
\text { continua }\end{array}$ & Produto & $\begin{array}{l}\text { Pós- } \\
\text { consumo }\end{array}$ \\
\hline $\begin{array}{l}\text { Fornell } \\
\text { (1992) }\end{array}$ & $\begin{array}{l}\text { Uma avaliação geral } \\
\text { pós-compra }\end{array}$ & Avaliação geral & $\begin{array}{l}\text { Performance } \\
\text { percebida pós- } \\
\text { compra } \\
\text { comparada com } \\
\text { expectativas } \\
\text { pré-compra }\end{array}$ & Pós-compra \\
\hline
\end{tabular}

continua 
continuação

\begin{tabular}{|c|c|c|c|c|}
\hline Fonte & Definição conceitual & Resposta & Foco & Tempo \\
\hline $\begin{array}{l}\text { Oliver } \\
(1992)\end{array}$ & $\begin{array}{l}\text { Examinando se } \\
\text { satisfação é uma } \\
\text { emoção, concluiu que } \\
\text { satisfação é um } \\
\text { fenômeno sumário, } \\
\text { coexistindo com outras } \\
\text { emoções relacionadas ao } \\
\text { consumo }\end{array}$ & $\begin{array}{l}\text { Atributo } \\
\text { sumário, } \\
\text { coexistindo com } \\
\text { outras emoções } \\
\text { de consumo }\end{array}$ & $\begin{array}{l}\text { Atributos do } \\
\text { produto }\end{array}$ & $\begin{array}{l}\text { Durante o } \\
\text { consumo }\end{array}$ \\
\hline $\begin{array}{l}\text { Westbrook } \\
\text { e Oliver } \\
\text { (1991) }\end{array}$ & $\begin{array}{l}\text { Um julgamento pós- } \\
\text { escolha, relativo a uma } \\
\text { seleção específica de } \\
\text { compra }\end{array}$ & $\begin{array}{l}\text { Julgamento de } \\
\text { avaliação }\end{array}$ & $\begin{array}{l}\text { Seleção de } \\
\text { fornecedor }\end{array}$ & Pós-escolha \\
\hline $\begin{array}{l}\text { Oliver e } \\
\text { Swan } \\
(1989)\end{array}$ & $\begin{array}{l}\text { Sem definição } \\
\text { conceitual. Uma função } \\
\text { de preferência e } \\
\text { desconfirmação }\end{array}$ & & Vendedor & $\begin{array}{l}\text { Durante a } \\
\text { compra }\end{array}$ \\
\hline $\begin{array}{l}\text { Tse e } \\
\text { Wilton } \\
(1988)\end{array}$ & $\begin{array}{l}\text { A resposta do } \\
\text { consumidor a avaliação } \\
\text { da discrepância entre } \\
\text { expectativas e } \\
\text { performance real de } \\
\text { produtos, percebida após } \\
\text { seu consumo }\end{array}$ & $\begin{array}{l}\text { Resposta a } \\
\text { avaliação }\end{array}$ & $\begin{array}{l}\text { Discrepância } \\
\text { percebida entre } \\
\text { expectativas e } \\
\text { perfomance real } \\
\text { do produto }\end{array}$ & $\begin{array}{l}\text { Pós- } \\
\text { consumo }\end{array}$ \\
\hline $\begin{array}{l}\text { Cadotte, } \\
\text { Woodruff } \\
\text { e Jenkins } \\
(1987)\end{array}$ & $\begin{array}{l}\text { O sentimento } \\
\text { desenvolvido de uma } \\
\text { avaliação sobre a } \\
\text { experiência de uso }\end{array}$ & $\begin{array}{l}\text { Sentimento } \\
\text { desenvolvido de } \\
\text { uma avaliação }\end{array}$ & $\begin{array}{l}\text { Experiëncia de } \\
\text { uso }\end{array}$ & $\begin{array}{l}\text { Durante o } \\
\text { consumo }\end{array}$ \\
\hline $\begin{array}{l}\text { Westbrook } \\
\text { (1987) }\end{array}$ & $\begin{array}{l}\text { Avaliação global sobre o } \\
\text { uso/consumo de } \\
\text { produtos }\end{array}$ & $\begin{array}{l}\text { Avaliação } \\
\text { global }\end{array}$ & $\begin{array}{l}\text { Uso/consumo } \\
\text { de produto }\end{array}$ & $\begin{array}{l}\text { Durante o } \\
\text { consumo }\end{array}$ \\
\hline $\begin{array}{l}\text { Day } \\
(1984)\end{array}$ & $\begin{array}{l}\text { A resposta a um evento } \\
\text { real de consumo baseada } \\
\text { na discrepância entre } \\
\text { expectativas e } \\
\text { performance real } \\
\text { percebida após sua } \\
\text { aquisição }\end{array}$ & $\begin{array}{l}\text { Resposta a uma } \\
\text { avaliação }\end{array}$ & $\begin{array}{l}\text { Discrepância } \\
\text { percebida entre } \\
\text { expectativa e } \\
\text { performance } \\
\text { real }\end{array}$ & $\begin{array}{l}\text { Durante o } \\
\text { consumo }\end{array}$ \\
\hline
\end{tabular}


continuação

\begin{tabular}{|c|c|c|c|c|}
\hline Fonte & Definição conceitual & Resposta & Foco & Tempo \\
\hline $\begin{array}{l}\text { LaBarbera } \\
\text { e } \\
\text { Mazursky } \\
(1983)\end{array}$ & $\begin{array}{l}\text { Avaliação pós-compra. } \\
\text { Uma avaliação da } \\
\text { surpresa inerente na } \\
\text { aquisição de um produto } \\
\text { e experiência de } \\
\text { consumo }\end{array}$ & Avaliação & Surpresa & $\begin{array}{l}\text { Pós-compra } \\
\text { e } \\
\text { experiência } \\
\text { de consumo }\end{array}$ \\
\hline $\begin{array}{l}\text { Westbrook } \\
\text { e Reilly } \\
\text { (1983) }\end{array}$ & $\begin{array}{l}\text { Uma resposta emocional } \\
\text { a uma experiência } \\
\text { proporcionada por } \\
\text { produtos ou serviços } \\
\text { adquiridos ou mesmo } \\
\text { por locais e } \\
\text { comportamentos de } \\
\text { vendedores. Uma } \\
\text { resposta emocional } \\
\text { disparada por um } \\
\text { processo de avaliação } \\
\text { cognitiva na qual as } \\
\text { percepções sobre um } \\
\text { objeto, ação ou condição } \\
\text { são comparados com } \\
\text { alguns valores } \\
\text { (necessidades, desejos) }\end{array}$ & $\begin{array}{l}\text { Resposta } \\
\text { emocional }\end{array}$ & $\begin{array}{l}\text { Experiência } \\
\text { provocada por e } \\
\text { asosciada com } \\
\text { produtos ou } \\
\text { serviços } \\
\text { adquiridos ou } \\
\text { mesmo com } \\
\text { locais e } \\
\text { comportamentos } \\
\text { de pessoas }\end{array}$ & Pós-compra \\
\hline $\begin{array}{l}\text { Churchill } \\
\text { e } \\
\text { Suprenant } \\
(1982)\end{array}$ & $\begin{array}{l}\text { Uma saída do processo } \\
\text { de compra e uso, } \\
\text { resultante da } \\
\text { comparação entre } \\
\text { benefícios e custos, } \\
\text { similar a uma atitude } \\
\text { que pode ser avaliada } \\
\text { pela satisfação com } \\
\text { vários atributos }\end{array}$ & Saída & $\begin{array}{l}\text { Comparação } \\
\text { entre Custos e } \\
\text { benefícios }\end{array}$ & $\begin{array}{l}\text { Pós-compra } \\
\text { e uso }\end{array}$ \\
\hline
\end{tabular}

continua 
conclusão

\begin{tabular}{|c|c|c|c|c|}
\hline Fonte & Definição conceitual & Resposta & Foco & Tempo \\
\hline $\begin{array}{l}\text { Oliver } \\
\text { (1981) }\end{array}$ & $\begin{array}{l}\text { Uma avaliação da } \\
\text { surpresa inerente a } \\
\text { aquisição de um produto } \\
\text { e sua experiência de } \\
\text { consumo. Em essência, o } \\
\text { estado psicológico } \\
\text { quando a emoção da } \\
\text { desconfirmação das } \\
\text { expectativas é } \\
\text { combinada com os } \\
\text { sentimentos sobre a } \\
\text { experiência de consumo }\end{array}$ & $\begin{array}{l}\text { Avaliação } \\
\text { emocional do } \\
\text { estado } \\
\text { psicológico }\end{array}$ & $\begin{array}{l}\text { Surpresa: } \\
\text { Desconfirmação } \\
\text { de expectativas }\end{array}$ & $\begin{array}{l}\text { Aquisição } \\
\text { de produto } \\
\text { e/ou } \\
\text { experiência } \\
\text { de consumo }\end{array}$ \\
\hline $\begin{array}{l}\text { Swan, } \\
\text { Trawick e } \\
\text { Carroll } \\
(1980)\end{array}$ & $\begin{array}{l}\text { Uma avaliação } \\
\text { consciente ou } \\
\text { julgamento cognitivo de } \\
\text { que um produto tem } \\
\text { performance boa ou } \\
\text { pobre ou de que o } \\
\text { produto é adequado ou } \\
\text { não para o uso }\end{array}$ & $\begin{array}{l}\text { Avaliação } \\
\text { consciente ou } \\
\text { julgamento } \\
\text { cognitivo }\end{array}$ & $\begin{array}{l}\text { Performance do } \\
\text { produto boa ou } \\
\text { pobre. Produto } \\
\text { adequado ou } \\
\text { não aos } \\
\text { propósitos }\end{array}$ & $\begin{array}{l}\text { Durante ou } \\
\text { após o } \\
\text { consumo }\end{array}$ \\
\hline
\end{tabular}

No contexto B2B, várias pessoas estão envolvidas na relação cliente-fornecedor e, portanto, para se determinar o nível de satisfação do cliente, todas essas pessoas devem ser ouvidas. Em geral, no processo de compras, as seguintes pessoas participam e podem contribuir para a satisfação/insatisfação do cliente: agentes de decisão, influenciadores, compradores, porteiros, pessoal do recebimento e controle da qualidade e, finalmente, usuários do produto ou serviço. Cada um destes atores tem suas próprias expectativas e experimenta de forma diferente a relação estabelecida nos processos de compra e utilização dos produtos e serviços adquiridos. 


\subsection{A SATISFAÇÃO DE CLIENTES COMO PARTE DA ESTRATÉGIA DAS EMPRESAS}

As organizações necessitam permanentemente verificar se o seu desempenho está compatível com as premissas estratégicas estabelecidas. Desvios do rumo estratégico traçado podem ter como conseqüência negativa a perda da competitividade, qualidade e, conseqüentemente, perda de mercado. Assim, o gerenciamento dos processos de uma empresa deve contar com indicadores que reflitam o seu desempenho e estejam alinhados com a consecução dos objetivos estratégicos.

Kaplan e Norton (1996) observam sobre um novo conjunto de premissas operacionais, as quais norteiam as empresas na era da informação:

a) Processos interfuncionais, transcendendo a especialização de habilidades funcionais;

b) Ligação com clientes e fornecedores, por meio da tecnologia da informação, permitindo a integração e otimização de toda a cadeia de valores;

c) Segmentação de clientes, com o fornecimento de produtos e serviços customizados para cada um dos segmentos;

d) Escala global, rompendo com as fronteiras nacionais e propiciando a livre concorrência;

e) Inovação, como fator preponderante da vantagem competitiva, induzindo redução nos ciclos de vida dos produtos e incorporação de novas tecnologias; 
f) Trabalhadores de conhecimento, onde os funcionários agregam valor pelo que sabem e pelas informações que podem fornecer.

Estas premissas deverão ser consideradas e equacionadas por meio de um gerenciamento integrado da organização.

Sink e Tuttle (1993) reforçam esta argumentação e salientam que o gerenciamento é o que cria e sustenta o nível de competitividade e finalizam concluindo que "será necessária uma congruência entre planos, processos de planejamento, sistemas de medição e avaliação, princípios orientadores e sistemas de recompensa, para que a organização se torne a Organização do Futuro. A falta de uma estratégia integrada e estudada de modo sistemático fez com que nossas intervenções de melhoria fossem menos eficazes e eficientes do que deveriam".

Para uma gestão eficaz, percebe-se a importância do estabelecimento da estratégia, do seu desdobramento nos diversos processos e do acompanhamento de sua realização com o auxílio de indicadores de desempenho, que estejam vinculados aos objetivos estratégicos.

Para um gerenciamento eficaz, Rummler \& Brache (1994) declaram ser a medição o ingrediente chave, pois a sua ausência influencia tanto o desempenho das organizações, como também afeta de maneira significativa o desempenho humano, e explicitam: 
a) "Sem medição, o desempenho não está sendo gerenciado;

b) Sem medição, não se pode identificar adequadamente os problemas, nem estabelecer um conjunto de prioridades;

c) Sem medição, as pessoas não podem compreender totalmente o que se espera delas;

d) Sem medição, as pessoas não têm certeza de que seu desempenho é adequado ou não;

e) Sem medição, não pode haver uma base objetiva e equiitativa para recompensas (como aumentos, bônus, promoções) ou punições (como ações disciplinares, rebaixamento, demissão);

f) Sem medição, não há gatilho para as ações de aperfeiçoamento do desempenho;

g) Sem medição, o gerenciamento é um conjunto de adivinhações desordenadas”.

Hronec (1993) considera as medidas de desempenho como "sinais vitais" da organização e as define como sendo "a quantificação de quão bem as atividades dentro de um processo ou seu output atingem uma meta especificada".

Harrington (1993) reforça que a revolução industrial está associada à evolução dos sistemas de medição. Contudo, salienta que há muito a se ganhar com o aperfeiçoamento dos sistemas de medição, principalmente relativos à aquisição do conhecimento, e finaliza argumentando "medir é entender, entender é adquirir conhecimento, adquirir conhecimento é ter poder". 
Existe uma gama de aplicações da medição nas organizações. Tradicionalmente a medição vem sendo utilizada com a conotação de controle. Com o passar dos anos, incorporou-se o conceito da medição ser um meio para a realização da melhoria contínua. Atualmente, a ênfase para o controle ou para a melhoria depende de uma análise da situação requerida pela organização, se bem que a utilização conjunta dos conceitos não é incompatível. Sink e Tuttle (1993) abordam, com propriedade, este tema e destacam alguns papéis representados pela medição:

a) A medição como o impulsionador da melhoria da performance;

b) A melhoria como impulsionador da medição;

c) A medição como ferramenta para assegurar que a estratégia seja implantada;

d) A medição como o sistema de apoio gerencial à tomada de decisão;

e) A medição como dispositivo de controle.

De acordo com Hronec (1993) as medidas de desempenho são abordadas segundo três dimensões:

a) Qualidade, a qual quantifica a excelência do produto ou serviço na visão do cliente,

b) Tempo, o qual quantifica a excelência do processo e é de interesse da administração;

c) Custos, o qual quantifica o lado econômico da excelência e dentre os diversos interessados, destacam-se a administração e os acionistas. 
De acordo com Kaplan e Norton (1996), o Balanced Scorecard é resultado de um estudo intitulado Measuring Performance in the Organization of the Future, realizado ao longo de um ano e motivado pela crença de que os indicadores contábeis financeiros não eram suficientes para medir o desempenho organizacional e gerar valor futuro para a organização. David Norton, executivo principal do Instituto Nolan Norton, liderou o estudo, tendo Robert Kaplan, professor de Harvard, como consultor acadêmico. A partir de um sistema de indicadores usado pela Analog Devices (empresa fabricante de semicondutores nos Estados Unidos, que além de indicadores financeiros elaborava também medidas de desempenho relacionadas à satisfação de clientes, qualidade e melhoria de processos), somados a outras idéias, originou-se o Balanced Scorecard.

O Balanced Scorecard mede o desempenho organizacional sob quatro perspectivas equilibradas: financeira, do cliente, dos processos internos e do aprendizado e crescimento, constituindo-se não em uma ferramenta de controle, mas em um sistema de comunicação e aprendizado. A Figura 2 demonstra as perspectivas do BSC. No entanto, Kaplan e Norton não fornecem quaisquer diretrizes para monitorar a satisfação dos clientes das organizações, limitando-se a descrever a importância de tais medições. 


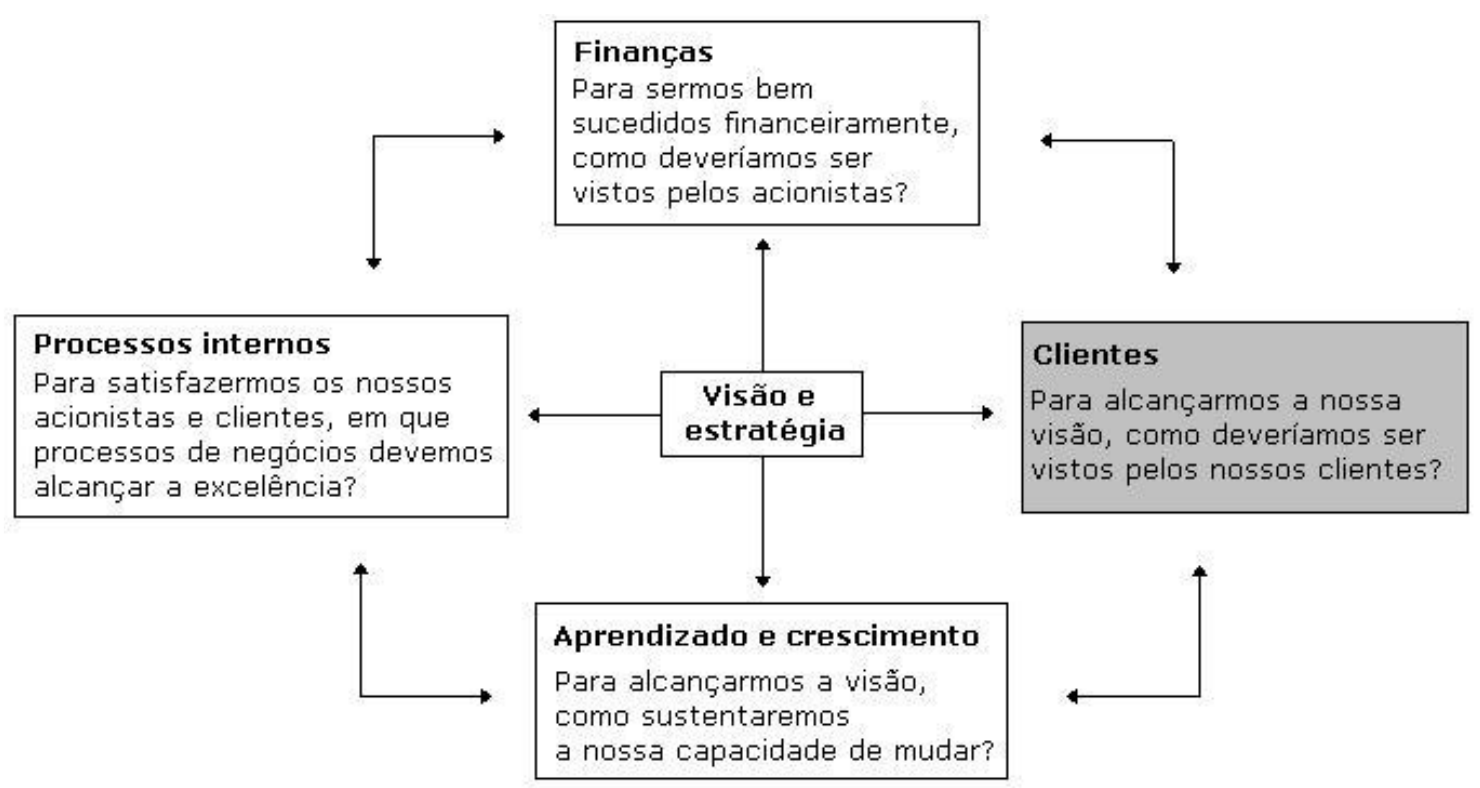

Figura 2 - Perspectivas do BSC

Fonte Adaptada de Kaplan e Norton (1996)

Fornell (1992) é um dos poucos autores a descrever com detalhes como a satisfação do cliente se integra à estratégia de negócios das empresas. Segundo o autor, devido à competição internacional em mercados maduros e de pequeno crescimento, cada vez mais um limitado número de clientes é assediado por um número cada vez maior de fornecedores, gerando como efeito da competição uma grande pressão sobre preços. Assim, meios de competição que reduzem a elasticidade de preços são de grande importância. Um elevado nível de satisfação do cliente pode ser um dos meios.

A Figura 3 mostra um modelo de estratégia geral do negócio que é composta de duas frentes, $\mathrm{o}$ ataque e a defesa. Virtualmente, todas as empresas aplicam uma combinação de estratégia de ataque e defesa. $\mathrm{O}$ ataque para ganhar novos clientes e a defesa para 
manter a base de clientes existentes. Tradicionalmente muito mais esforço é necessário para conquistar novos clientes do que para mantê-los. Gastos enormes são realizados em propagandas. Apesar de uma boa parte da propaganda ser dirigida aos clientes existentes, a maior parte dos custos se destina ao ataque. Devido ao pequeno crescimento e elevada competitividade dos mercados, entretanto, uma boa estratégia de defesa torna-se crítica para o negócio. Quando empresas crescem aumentando seu market share, empresas com defesa fraca são as primeiras a sofrer. Em muitos casos, a atenção dada à defesa tem sido lenta ou insuficiente, tendo como resultado típico uma "erosão" na base de clientes.

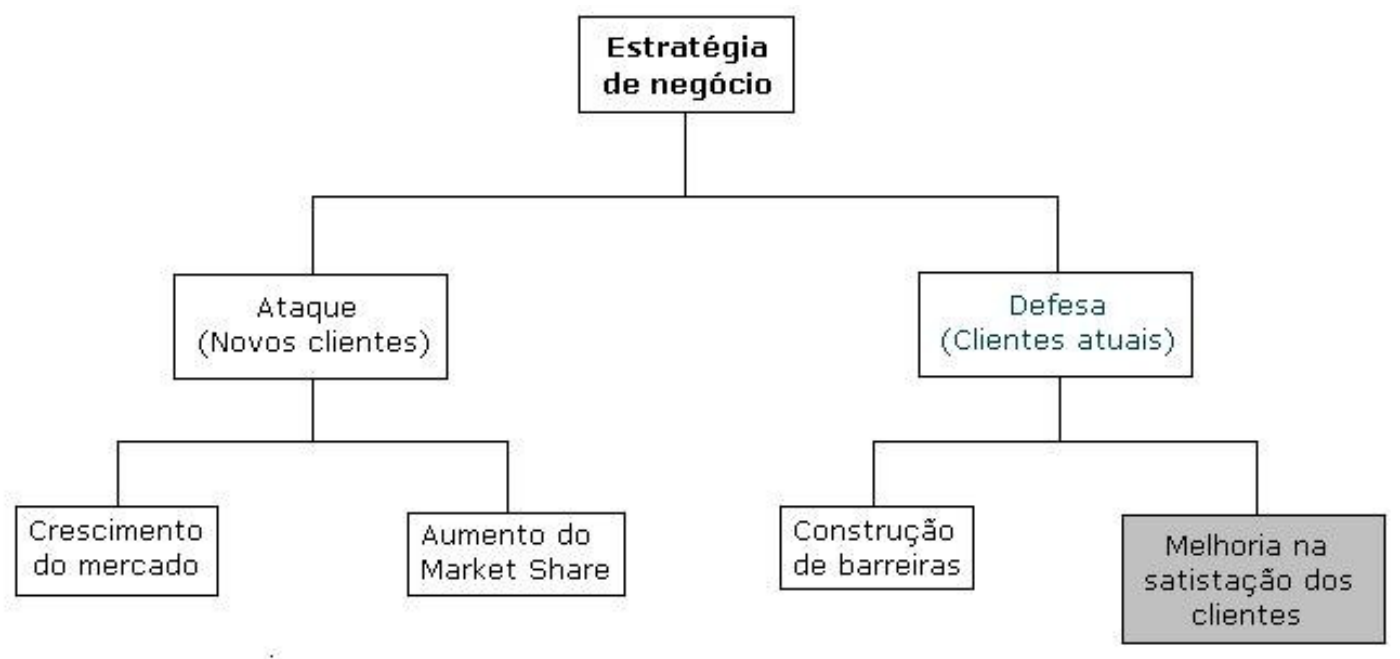

Figura 3- Modelo de Estratégia

Fonte: Fornell (1992)

A estratégia de defesa envolve a redução da fuga de clientes e barreiras. O objetivo da estratégia defensiva é minimizar o turnover de clientes (maximizar a retenção) 
protegendo produtos e mercado de competição de entrantes. Uma forma de se atingir este objetivo é ter um elevado nível de satisfação de cliente.

No inicio dos anos 70 a busca de market share tornou-se uma parte chave das estratégias das empresas. Sua maximização era considerada uma forma de elevar a lucratividade de empresas e melhorar a economia do país em termos de eficiência e produtividade (Henderson, apud Fornell,1992). Ao se analisar as estratégias de ataque e defesa, percebe-se que abordagens de market share e satisfação de cliente são utilizadas sob as mesmas condições.

A tabela 3 mostra os fundamentos da estratégia de market share em relação à satisfação do cliente.

Tabela 3 - Market share x Satisfação do cliente Fonte: Fornell (1992)

\begin{tabular}{|c|c|c|}
\hline & MARKET SHARE & $\begin{array}{l}\text { SATISFAÇÃO DO } \\
\text { CLIENTE }\end{array}$ \\
\hline $\begin{array}{l}\text { Tipicamente } \\
\text { empregados em }\end{array}$ & $\begin{array}{l}\text { Baixo crescimento ou } \\
\text { mercados saturados }\end{array}$ & $\begin{array}{l}\text { Baixo crescimento ou } \\
\text { mercados saturados }\end{array}$ \\
\hline Tipos de Estratégia & Ataque & Defesa \\
\hline Foco & Competidores & Clientes \\
\hline Medida de Sucesso & $\begin{array}{c}\text { Share do mercado resultante } \\
\text { da competição }\end{array}$ & $\begin{array}{c}\text { Razão de retenção de } \\
\text { Clientes }\end{array}$ \\
\hline $\begin{array}{l}\text { Objetivo } \\
\text { Comportamental }\end{array}$ & $\begin{array}{c}\text { Controlar } \\
\text { Comprador }\end{array}$ & $\begin{array}{c}\text { Fidelizar } \\
\text { Comprador }\end{array}$ \\
\hline
\end{tabular}


Ambas as estratégias freqüentemente são usadas sob as mesmas condições de mercado, baixo crescimento e saturação, ou seja, onde há pouco espaço para empresas crescerem sem a competição. Conquistar market share é uma estratégia de ataque; criar satisfação do cliente é uma estratégia de defesa. Sucesso e fracasso na estratégia de market share são avaliados em relação aos concorrentes. Para a estratégia de satisfação do cliente, sucesso e fracasso são avaliados pelo nível de retenção de clientes. Os custos, como resultado, são tipicamente maiores para o ataque devido ao maior esforço necessário para criar controles do que para manter o status quo.

A análise das abordagens estratégicas pode nos levar a conclusão equivocada de que a busca da satisfação do cliente leve à perda de market share. De fato, altos níveis de satisfação podem produzir propaganda boca a boca favorável, e isso gera um impacto positivo no market share. Entretanto, ganhos de market share implicam em aumento de heterogeneidade da base de clientes, podendo levar à redução do nível de satisfação, principalmente quando as preferências dos clientes não são homogêneas.

Como sugerido na Figura 3, ataques têm duas formas básicas:

a) Obtendo novos clientes pela expansão do mercado e,

b) aumentando o market share, através da competição.

Em princípio, a estratégia de defesa também tem duas formas básicas:

a) Criação de barreiras e

b) satisfação do cliente. 
Criar barreiras significa tornar oneroso ao cliente trocar de fornecedor (vendedor, loja, etc). A satisfação de cliente, em contraste, torna oneroso ao concorrente conseguir um novo cliente. Isto é, no primeiro caso, a empresa torna difícil, oneroso ou mesmo ilegal, o cliente substituir o fornecedor. Formas de barreiras podem ser exemplificadas por custos de pesquisa, custos de transação, custos de aprendizagem, descontos para clientes fiéis e esforços cognitivos, combinados com riscos financeiros, sociais e psicológicos da parte do comprador. Outros são custos de re-treinar pessoas, aquisição de novos equipamentos, etc.

É comum encontrar no mercado empresas usando uma combinação de barreiras e satisfação. Um exemplo ocorre no serviço de transporte aéreo em que as empresas fornecem incentivos para manter o cliente fiel, através de programas de milhagem. Tal fenômeno ocorre com maior freqüência em empresas aéreas americanas e em menor escala nas companhias européias e orientais, nas quais a satisfação do cliente é privilegiada em detrimento das barreiras. De modo geral, não é possível determinar se a satisfação é mais efetiva que a barreira, mas dois problemas imediatos com barreiras não estão presentes na abordagem de satisfação. O primeiro é óbvio: se o cliente é informado da barreira no ato da compra, a barreira se torna um impedimento de estratégia de ataque. A presença de barreiras faz com que as primeiras vendas sejam mais difíceis. O oposto é verdadeiro para a satisfação do cliente. Elevada satisfação é um ativo para o ataque. 
O segundo problema com barreiras é que elas podem ser eliminadas por forças externas. Programas de vôo podem ser facilmente imitados e a barreira derrubada. Quando isso ocorre, a arma competitiva da barreira pode tornar-se rapidamente desabilitada e, normalmente, como tais empresas não realizam investimentos em qualidade e satisfação de cliente fica inevitável a fuga de clientes.

\subsection{OS MODELOS NACIONAIS DE SATISFAÇÃO DE CLIENTES}

Segundo Bruhn e Grund (2000), a crescente intensidade de competição em muitas indústrias leva a mudanças nos objetivos das empresas. No passado, o foco era atrair novos clientes, mas agora, a estratégia das empresas tem se dirigido no sentido de manter os clientes existentes e melhorar a fidelização.

Aceitar esta nova condição implica em uma forte necessidade de analisar os fatores que levam à satisfação e lealdade do cliente. No passado, a correspondente pesquisa era realizada por empresas isoladamente, gerando resultados não comparáveis nem em empresas do mesmo segmento e muito menos entre segmentos distintos ou mesmo entre países. A internacionalização de economia requer conceitos de benchmarking para competidores nacionais e internacionais.

Torna-se muito difícil conduzir políticas econômicas sem medições precisas e compreensíveis. A satisfação do consumidor tem um considerável valor como complemento às medidas tradicionais. Isto é verdade tanto para o nível macro quanto 
micro. Por ser derivado de dados de consumo e não de produção, é também um indicador de lucros futuros. A satisfação do consumidor precede a sua fidelidade (Anderson e Sullivan, 1993; Bearden e Teel, 1983; Bolton e Drew, 1991; Fornell, 1992; La Barbera e Mazursky, 1983; Oliver, 1980; Oliver e Swan, 1989; Yi, 1990).

As comparações de satisfação de clientes (e correspondentes drivers de satisfação) são necessárias não somente em um setor, mas também entre setores (perspectiva macroeconômica) e mesmo entre países. Usualmente estes dados não estão disponíveis e seria muito caro, para uma única empresa, obter tais informações. Desta forma, nos últimos anos, diferentes países têm estabelecido seus índices de satisfação de clientes. O resultado da análise para um segmento específico através da comparação de empresas do mesmo setor pode ser utilizado para futuras estratégias.

Índices Nacionais de Satisfação de Cliente fornecem benefícios adicionais para diferentes stakeholders. No micro-nível de cliente individual, o resultado do índice pode ser utilizado para decisões de consumo. No macro-nível, os resultados são indicações para desenvolvimento da competitividade nacional.

Um índice nacional de satisfação de cliente pode ser descrito como uma medição de satisfação como fator crítico de sucesso, de empresas e instituições, consistindo de vários setores de um país ou área da economia, por meio de análise periódica e realizado por uma instituição neutra (Bruhn e Grund, 2000). 
Com relação aos objetivos mencionados e considerando o trabalho teórico no campo de satisfação/insatisfação, uma abordagem confiável para medição de satisfação de clientes em nível nacional deve atender cinco requisitos importantes.

a) Medições diferenciadas de satisfação de cliente.

O primeiro passo é medir a satisfação geral com um produto, serviço ou fornecedor. Como as pesquisas demonstram, as medições de constructos complexos (tal como a satisfação), com um indicador único (abordagem de item simples) não asseguram ótimos resultados (Churchil e Homburg, apud Bruhn e Grund, 2000).

b) Identificação das pré-condições de Satisfação de Cliente.

Além de obter dados de satisfação, os drivers principais para satisfação de cliente devem ser identificados.

c) Identificação das conseqüências da satisfação do Cliente.

Olhando para as consequiências da satisfação do cliente, ou seja, seus efeitos sobre o comportamento do cliente e intenções devem ser examinados (exemplo, intenção de re-compra).

d) Identificação das relações causais.

Uma significativa abordagem para medir satisfação de cliente deve ser capaz de analisar as relações entre os constructos. Portanto, é necessário o uso de um modelo estrutural. De acordo com a abordagem multi-itens o modelo deve incluir variáveis 
latentes (exógenas e endógenas) e indicadores como base para a conceitualização de um índice nacional de satisfação do cliente.

e) Comparabilidade de resultados em níveis diferentes.

Com relação aos objetivos de benchmarking ao nível de empresas e setores (e mesmo nações) deve ser comparado. Portanto, o modelo estrutural e os drivers de satisfação de cliente devem ser padronizados o máximo possível.

Serão analisados neste trabalho três índices nacionais, o sueco, o americano e o suíço.

\subsubsection{O Barômetro Sueco}

O Barômetro Anual de Satisfação do Cliente (CSB- Consumer Satisfaction Barometer) mede a satisfação de clientes em mais de 30 setores da economia com dados obtidos de 100 corporações, complementando as medições nacionais de produtividade. Considerando que a produtividade mede basicamente quantidades, o CSB mede a qualidade destas "quantidades" (como experimentado pelo comprador). Fornell (1992) relata os resultados de um esforço de larga escala realizado para medir qualidade do processo de consumo como satisfação do cliente.

"Em um esforço para promover a qualidade e tornar sua indústria mais competitiva, a Suécia foi o primeiro país a estabelecer um indicador econômico para refletir a satisfação do cliente. A extensão na qual as empresas são capazes de satisfazer seus 
clientes é um indicador da saúde geral de seu futuro. O CSB é um índice baseado num survey anual com o objetivo de obter dados de cerca de 100 empresas líderes em 30 setores. É uma composição balanceada que determina o nível de satisfação dos clientes das empresas incluídas na pesquisa. Adicionalmente a relação do CSB com lealdade do cliente como também em relação ao desempenho de produtos e serviços é também estimada pelo modelo".

Fornell (1992) comenta que devido à satisfação do cliente ter um impacto direto sobre as fontes primárias de rendimentos futuros para muitas empresas, o índice é um importante complemento às medições de performance da economia, proporcionando valiosas informações não somente para as empresas, mas também para investidores, governo e compradores.

Se a satisfação do cliente é um indicador da saúde das empresas, os Índices Nacionais são medidas de performance orientada para o futuro. Alguns autores (ex: Kotler, 1988) consideram a satisfação do cliente o melhor indicador de lucros futuros das empresas. Assim, o CSB foi projetado para ser uma medição complementar, orientada para o futuro dos tradicionais indicadores. De acordo com Fornell (1992), a satisfação de cliente é provavelmente menos sensível às flutuações sazonais. O CSB foi criado para fornecer as seguintes informações: 
a) Comparação entre industrias (setores)

O governo sueco possui dados de reclamações sobre problemas de qualidade em várias indústrias. Um índice de satisfação complementa estas informações. Complementa também medições tradicionais, como por exemplo, produtividade.

b) Comparação de empresas individuais com a média do setor.

Em geral, pode-se esperar maiores margens e maior lealdade do cliente para empresas com alto grau de satisfação.

c) Comparação ao longo do tempo.

O CSB é um índice dinâmico e contínuo. Ele proporciona informações sobre empresas (melhoria e declínios) e suas tendências gerais.

d) Previsões sobre a performance futura.

Embora as evidências empíricas sejam limitadas acredita-se que o aumento na satisfação do cliente eleva a curva de demanda, reduz os custos de marketing e eleva os mesmos custos para os concorrentes, reduz custos de transações, reduz o turnover de clientes e funcionários (clientes satisfeitos afetam positivamente a satisfação do pessoal da linha de frente), melhora a reputação (boca a boca positiva) e reduz custo de falhas. Como resultado, clientes satisfeitos podem ser vistos como um investimento.

O modelo se propõe a dar respostas a questões específicas tais como a sensibilidade de vários setores da economia à satisfação de cliente, os efeitos de qualidade geral e 
preços, o impacto de expectativas do cliente, a melhoria da qualidade necessária para reter clientes insatisfeitos, sensibilidade a preços, reclamações de clientes e efeitos do boca a boca.

Três princípios fundamentais guiam o modelo sueco:

a) Reconhece-se que os significados das variáveis dependem do contexto na qual são aplicadas;

b) Toda pesquisa survey de variáveis é realizada com algum erro;

c) O constructo "Satisfação de Cliente" não é diretamente observável (Howard e Sheth, 1969; Oliver, 1981; Westbrook e Reilly, 1983).

A tarefa é, portanto, especificar um sistema de saídas de pós-compra no qual a satisfação do cliente é uma parte. Assim, o índice é especificado como uma composição de variáveis latentes em um sistema representado por múltiplas equações onde a medição do erro é considerada. Cada empresa individual é estimada separadamente de forma a capturar diferenças nas relações com respeito a como variáveis latentes se relacionam com seus indicadores e entre eles.

A Figura 4 mostra o modelo do barômetro sueco. 


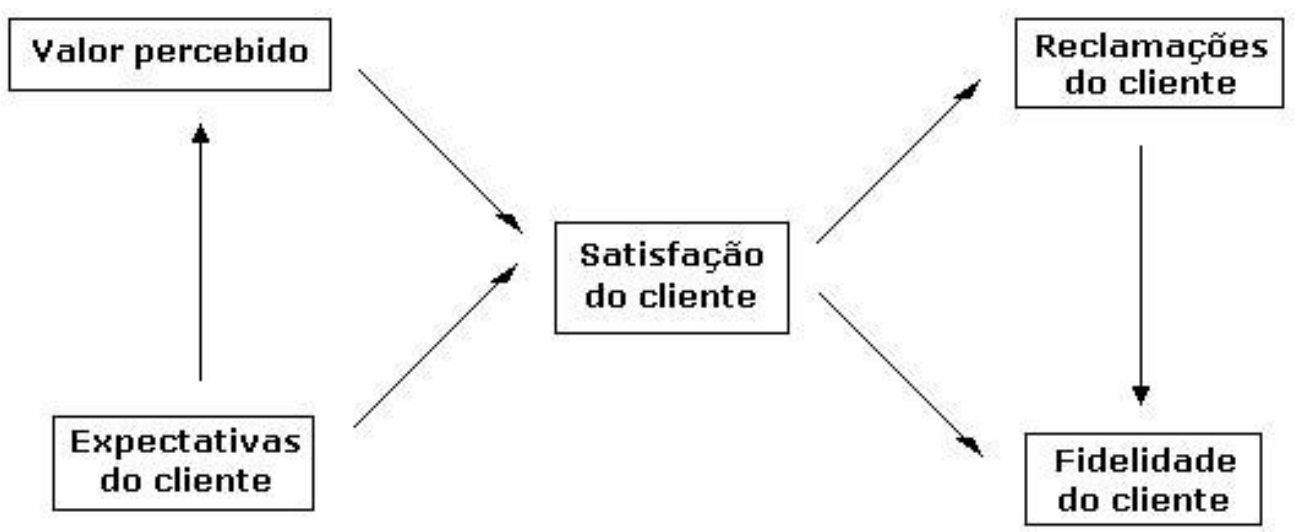

Figura 4 - Modelo Sueco

Fonte Fornell (1992)

\subsubsection{O Índice Americano}

O American Customer Satisfaction Index (ACSI) foi desenvolvido em 1994, seguindo o modelo sueco. Os objetivos do ACSI são gerar informações exatas e compreensivas sobre satisfação de clientes e servir como um indicador para o sucesso econômico de empresas, setores e economia nacional. O National Quality Research Center da Universidade de Michigan conduziu o trabalho de campo para o ACSI.

O ACSI é um projeto de parceria da American Society for Quality (ASQ), da Universidade de Michigan, o National Quality Research Center e a consultoria Arthur Andersen. Cerca de 25 patrocinadores corporativos dão suporte ao ACSI.

O ACSI é baseado em um modelo estrutural consistindo de seis variáveis latentes. A Figura 5 mostra o modelo estrutural com suas variáveis e suas relações. As variáveis latentes são medidas através de uma abordagem multi-itens. Usando análise causal, os 
pesos para indicadores assim como a relação entre variáveis são estimados através do método PLS - Partial Least Squares.

O ACSI utiliza uma escala de 10 pontos. Enquanto que o barômetro sueco é pesquisado uma vez ao ano, a pesquisa fundamental do ACSI foi realizada em 1994 e é atualizada trimestralmente para um ou dois setores. Desta forma, ao longo do ano, o índice é calculado sucessivamente.

Segundo Anderson e Fornell (2000), o ACSI utiliza o caminho mais direto para saber quão satisfeito ou insatisfeito o consumidor está: perguntando a ele. Consumidores são solicitados a avaliar produtos e serviços que compraram e utilizaram. Para o índice tornar-se "utilizável" precisa conter critérios relacionados com seus objetivos, devendo atender certas propriedades. São elas: precisão, validade, confiabilidade, poder de previsão, segurança, simplicidade, diagnose e comparabilidade.

De acordo com o modelo, a satisfação do Consumidor tem três antecedentes: qualidade percebida, valor percebido e expectativa do consumidor.

Qualidade percebida ou performance é a avaliação do mercado de experiências recentes de consumo. A segunda variável determinante é o valor percebido ou qualidade relativa ao preço pago. Ao incorporar o conceito de valor, pode-se comparar os resultados entre empresas, indústrias e setores de economia. O terceiro determinante é a expectativa do mercado, determinada pelo que as empresas oferecem, incluindo 
informações disponíveis através de fontes tais como publicidade e propaganda boca a boca e previsões sobre a habilidade do fornecedor em fornecer qualidade no futuro.

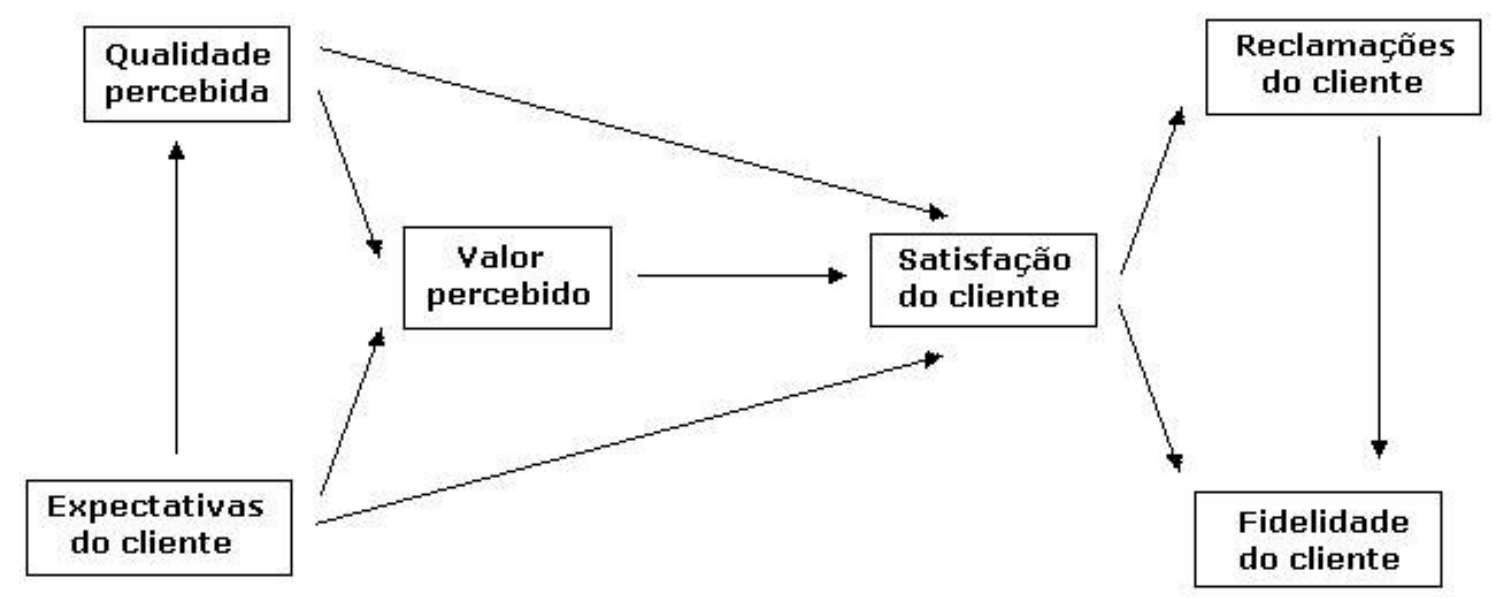

Figura 5- Modelo Americano

Fonte: Anderson e Fornell (2000)

\subsubsection{O Modelo Suíço}

De acordo com Bruhn e Grund (2000), o desenvolvimento do Índice Nacional de Satisfação de Cliente para a Suíça teve inicio em 1996 com um projeto de pesquisa da Universidade de Bosel.

Quatro principais objetivos foram propostos: 
a) Os interesses dos principais Stakeholders deveriam ser considerados. A implementação do Índice deveria conscientizar o gerenciamento da qualidade e orientar os clientes;

b) O ajuste do modelo deveria ser utilizado para diferentes situações: setores de produtos e serviços, setores com companhias dominantes (exemplo, monopólio) como também setores de alta competitividade;

c) Antes da implementação do Índice Nacional a técnica de coleta de dados deveria ser testada. O teste deveria evidenciar a facilidade do consumidor em responder ao questionário para dois segmentos;

d) Modificações do modelo estrutural (comparado com o sueco e americano) como também os modelos de medição deveriam ser analisados. As mais importantes modificações seriam a introdução de uma nova variável latente (diálogo com o consumidor) e a extensão do modelo para medição da fidelidade.

Adicionalmente às variáveis usadas para análise de causa, os drivers de satisfação para todos os setores foram fixados. Estes drivers não foram incluídos no modelo estrutural, mas foram analisadas suas influências no julgamento de satisfação.

O constructo "satisfação do cliente" é o mais importante constructo do modelo (BRUHN e GRUND, 2000). Como mostrado na Figura 6, satisfação de cliente é medida por três indicadores: a satisfação global com produtos e serviços, a satisfação comparada com expectativas antes do consumo e a satisfação comparada com um produto ou serviço ideal. Um novo constructo é a variável latente "diálogo com o 
cliente" também medida por três variáveis: a prontidão de contato com a empresa, a facilidade de diálogo e satisfação com o diálogo. O modelo supõe que clientes satisfeitos são mais interessados em um diálogo duradouro que outros e que eles se sentem mais fiéis à empresa. Fidelidade do cliente é a segunda variável endógena no modelo estrutural.

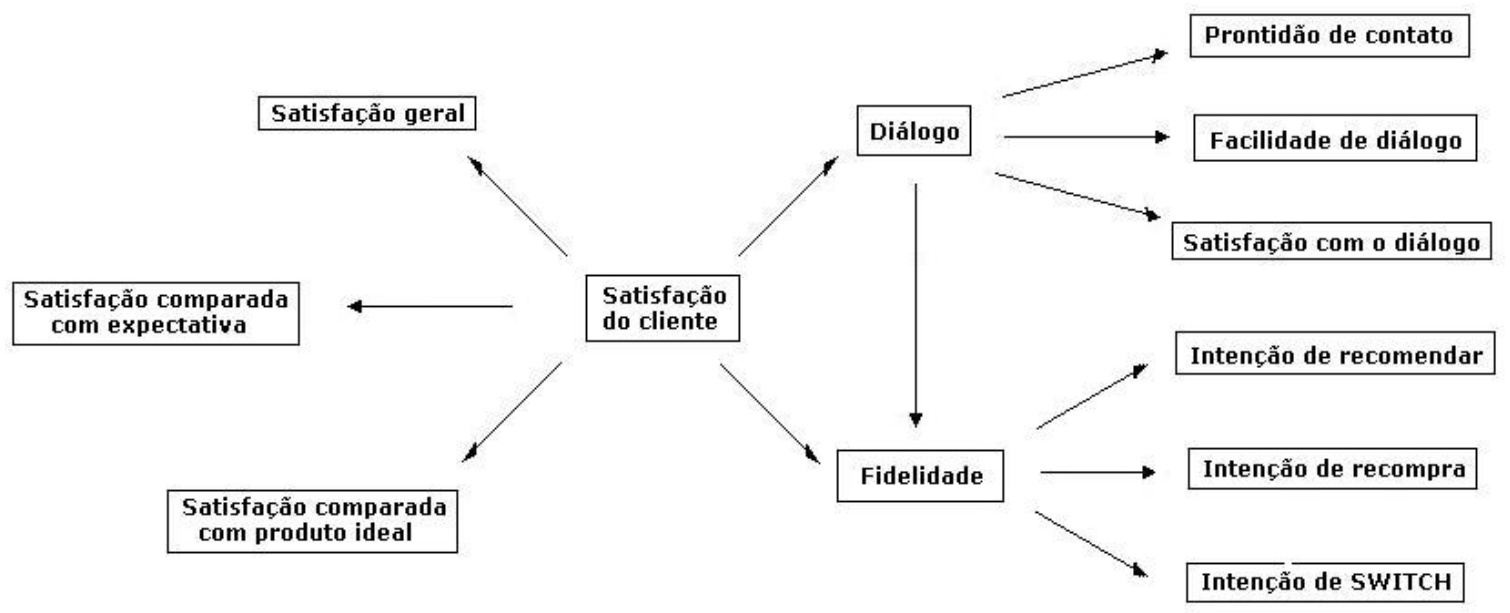

Figura 6 - Modelo Suíço

Fonte: Bruhn e Grund (2000)

\subsection{A SATISFAÇÃO DE CLIENTE E O MODELO ISO 9000}

O conjunto de normas da série ISO 9000 é mundialmente reconhecido e estabelece requisitos para o estabelecimento de Sistemas de Gestão da Qualidade para qualquer tipo de organização, seja ela uma prestadora de serviços ou fabricante de produtos. A primeira versão deste conjunto de normas foi publicada em 1987 e, desde então, tem produzido um grande impacto no comércio internacional. A organização não- 
governamental International Organizational for Standardization (ISO), criada em 1946, com sede em Genebra, Suíça, é responsável pela criação da série. No Brasil, A ISO é representada pela Associação Brasileira de Normas Técnicas (ABNT), responsável pela elaboração de normas nacionais e tradução e divulgação da série ISO 9000. A série está em sua terceira versão, publicada em dezembro de 2000 e no Brasil recebe o código NBR (Norma Brasileira) antes do respectivo código ISO. (Ex. NBR ISO 90042000, para sua equivalente internacional ISO 9004-2000).

Do conjunto da série, a norma que estabelece os requisitos para fins de obtenção de certificados é a ISO 9001-2000. Os certificados ISO 9001-2000 são emitidos por empresas certificadoras acreditadas pelo Instituto Nacional de Metrologia e Qualidade Industrial (INMETRO), integrante de um Sistema Internacional de Certificação.

A ISO 9000 foi adotada por 161 países em todos os continentes. Segundo dados da ABNT e da ISO, deve haver mais de 560.000 certificados emitidos em todo o mundo. No Brasil, dados do Comitê Brasileiro da Qualidade (CB-25) da ABNT obtidos no mês de Junho de 2006, indicam a existência de 8264 certificados emitidos e válidos.

O conjunto de normas preconiza a existência de oito princípios de Gestão da Qualidade, que são:

a) Foco no cliente;

b) liderança;

c) envolvimento de colaboradores;

d) gerenciamento por processos; 
e) abordagem sistêmica;

f) melhoria contínua;

g) abordagem factual para tomada de decisões;

h) vantagens mútuas nas relações com fornecedores.

Destes princípios, o primeiro deles está diretamente relacionado ao objeto do presente estudo.

Segundo Hoyle e Peach apud Pinto (2005), “as empresas necessitam de seus clientes para sobreviver e, portanto, devem conhecê-los profundamente e procurar superar as suas expectativas atuais e futuras. Pode-se executar tal item através da medição da satisfação do cliente, da posterior atuação sobre os resultados verificados e do adequado gerenciamento do relacionamento com os clientes. Os benefícios são a melhoria na elaboração das estratégias e políticas para a gestão do relacionamento com os clientes e o ajuste oportuno dos objetivos da qualidade às expectativas dos mesmos".

O monitoramento da satisfação do cliente é requisito explicito da norma ISO 90012000 e sujeito à avaliação dos auditores durante o processo de certificação das empresas. 


\subsection{PRINCIPAIS MODELOS UTILIZADOS PELAS EMPRESAS E CITADOS NA LITERATURA}

\subsubsection{A Escala SERVQUAL de Parasuraman, Zeithaml e Berry}

O modelo de Gap e a escala SERVQUAL foram criados por Parasuraman, Zeithaml e Berry (1988) após uma pesquisa cujo objetivo era desenvolver um instrumento para medir a qualidade de serviços considerando a percepção do cliente. As dúvidas para as quais os autores buscavam respostas eram as seguintes:

a) Como exatamente os clientes avaliam os serviços?

b) Fazem direto uma avaliação global?

c) Fazem uma avaliação de facetas específicas para chegar a uma avaliação global?

d) Se for assim, quais são essas facetas?

e) Essas facetas variam de serviço para serviço?

f) Elas variam entre segmentos de clientes?

A pesquisa foi realizada com clientes de empresas americanas de quatro setores de serviços: banco de varejo, cartões de crédito, corretagem de seguros e reparo e manutenção de produtos. As questões levantadas nas entrevistas referiam-se ao que seria considerado um serviço ideal, significado da qualidade do serviço, fatores considerados na avaliação da qualidade do serviço. Como observação das entrevistas, os autores concluíram que a qualidade pode ser considerada como o grau de 
discrepância entre as expectativas do cliente e suas percepções com relação ao serviço recebido.

De acordo com Parasuraman, Zeithaml e Berry (1985), foi possível identificar os critérios que os clientes utilizam para avaliar a qualidade dos serviços, denominados dimensões da qualidade, agrupadas conforme a tabela 4.

Tabela 4 - Dimensões da escala SERVQUAL

Fonte: Parasuraman, Zeithaml e Berry (1985)

\begin{tabular}{|ll|}
\hline Dimensão & Definição \\
\hline Tangibilidade & $\begin{array}{l}\text { Aparência das instalações, equipamentos, } \\
\text { pessoal e materiais de comunicação. }\end{array}$ \\
\hline Confiabilidade & Capacidade de prestar o serviço prometido de \\
& forma confiável e precisa. \\
\hline Presteza & Disposição para ajudar o cliente e prestar \\
& prontamente o serviço. \\
\hline Segurança & Conhecimento e cortesia dos empregados e \\
& sua capacidade de inspirar segurança e \\
& confiança. \\
\hline Empatia & Atenção cuidadosa e individualizada que a \\
& organização proporciona a seus clientes. \\
\hline
\end{tabular}

A tabela 5 mostra o instrumento SERVQUAL com seus 22 itens para expectativa e desempenho. 


\section{Tabela 5 - Instrumento SERVQUAL}

\section{Fonte: Parasuraman, Zeitthaml e Berry, 1988}

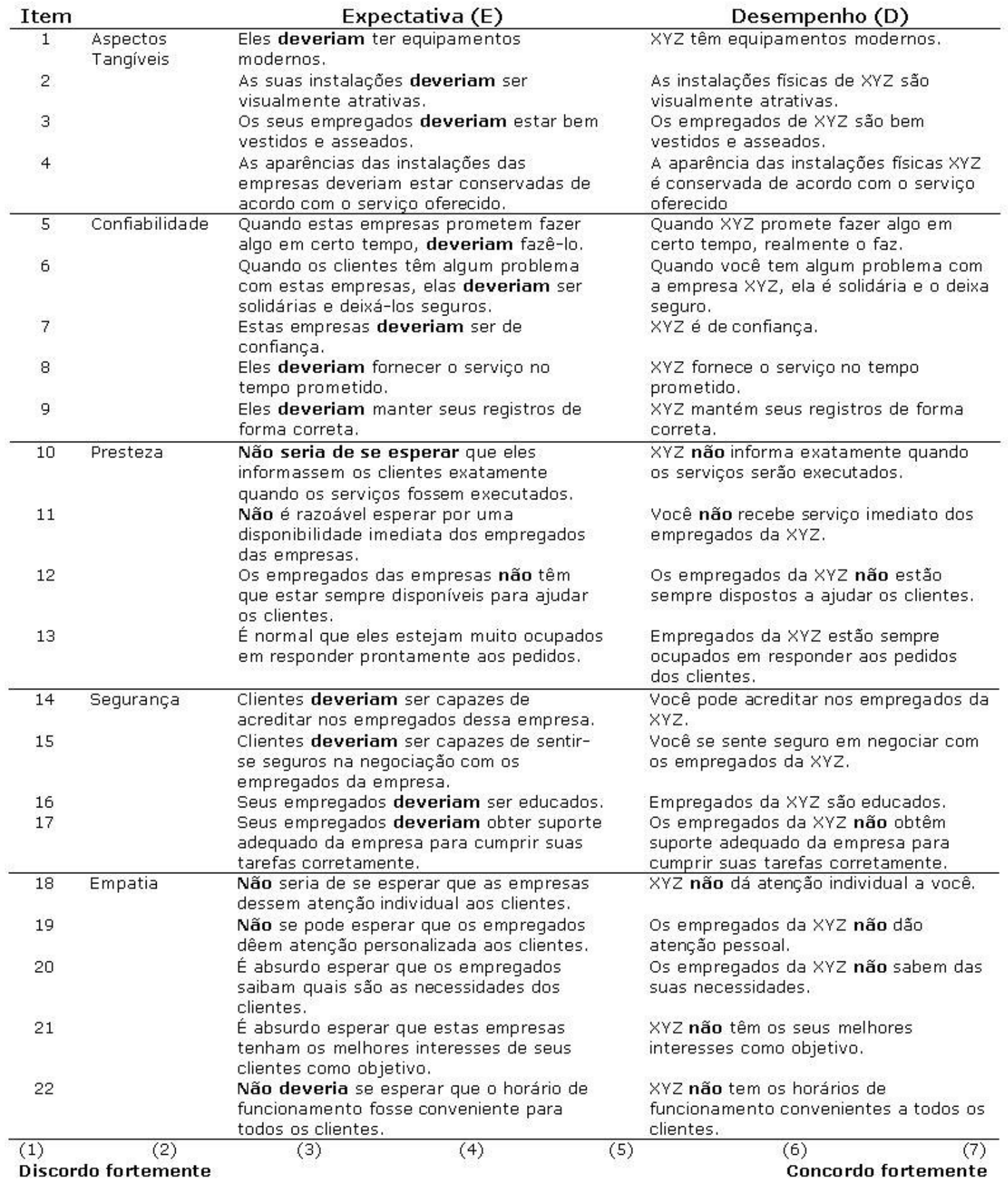


Os estudos dos autores ainda contemplam entrevistas com os executivos das empresas cujos clientes foram entrevistados a fim de identificar as causas potencias das divergências entre o serviço realizado e aquele percebido pelo cliente; os autores concluíram que as maiores causas dessas divergências são causadas por uma série de discrepâncias que se inter-relacionam e se acumulam; estas formam o Modelo de Conceitual da Qualidade ou Modelo de Análise de Gap da Qualidade, sendo composto por cinco Gaps descritos abaixo:

a) GAP 1: Representa a discrepância entre a expectativa do cliente e a percepção da Gerência sobre essas expectativas;

b) GAP 2: Representa a discrepância entre as percepções que a Gerência tem das expectativas do cliente e a especificação da qualidade do serviço;

c) GAP 3: Representa a discrepância entre as especificações da qualidade do serviço e a produção do serviço;

d) GAP 4: Representa a discrepância entre o serviço prestado e a comunicação externa com o cliente;

e) GAP 5: Representa a discrepância entre o serviço esperado e o recebido.

As principais características do modelo são:

a) Utiliza como princípio o paradigma da desconfirmação;

b) Conjunto de 22 variáveis/itens cobrindo 5 diferentes dimensões da qualidade de serviço;

c) Escala constituída de 44 itens (22 para expectativa e 22 para percepções);

d) Respostas obtidas em escala Likert de 7 pontos. 
A escala SERVQUAL é bastante utilizada e igualmente criticada, sendo as principais críticas as seguintes:

a) Score $(\mathrm{P}-\mathrm{E})$ não fornece o exato nível de performance;

b) Questionários longos;

c) Validade da estrutura de 5 dimensões;

d) Dificuldade de conceituar expectativa, sendo a mesma objeto de múltiplas interpretações;

e) Modelo não trabalha a amostragem; basicamente trabalha na validação das dimensões estabelecidas.

\subsubsection{A Escala Servperf de Cronin e Taylor}

Como alternativa à escala SERVQUAL, Cronin e Taylor (1992) propuseram uma nova forma de medição, chamada escala SERVPERF, através da eliminação do componente expectativa e baseada somente na percepção do desempenho. Justificando seu modelo, Cronin e Taylor (1992) ressaltam que a qualidade é mais conceituada como uma atitude do cliente com relação às dimensões da qualidade e que não deve ser medida com base no modelo de satisfação de Oliver (1980), ou seja, não deve ser medida por meio de diferenças entre expectativa e desempenho, e sim como uma percepção de desempenho somente. Para os autores, a qualidade percebida é um antecedente à satisfação e que a satisfação tem um efeito significativamente maior que a qualidade 
percebida nas intenções de compra, ou seja, em última análise, o desempenho (medida de satisfação) é o que realmente interessa.

Dessa forma, Cronin e Taylor (1992) desenvolveram a escala SERVPERF, alegando ser um instrumento mais adequado que a escala SERVQUAL de Parassuraman, Zeithamn e Berry (1988). No desenvolvimento de seu modelo, Cronin e Taylor (1992), consideraram inicialmente que os 22 itens da escala SERVQUAL estavam suficientemente fundamentados e, portanto são adequados. Em seu trabalho, Cronin e Taylor (1992) concluem que o instrumento SERVPERF é mais sensível em retratar as variações de qualidade em relação às outras escalas testadas (SERVQUAL, SERVQUAL ponderada e SERVPERF ponderada). Tais conclusões foram obtidas por meio de estudos estatísticos aplicando testes do qui-quadrado e regressão linear. Através de modelos de equações estruturais de variáveis latentes, os autores também concluíram que a qualidade leva à satisfação, contrariando estudos de outros autores que afirmam que a satisfação é um antecedente da qualidade, como por exemplo, Bolton e Drew (1991).

As principais características do modelo são:

a) Derivada da SERVQUAL;

b) Componente "expectativa" da SERVQUAL foi eliminada, mantendo os 22 itens para a percepção;

c) Escala Likert de 7 pontos;

d) Não usa Gap SERVQUAL; 
e) Redução de 50\% no número de itens em relação à SERVQUAL

\subsubsection{O Modelo Probabilístico de Erto e Vanacore}

Erto e Vanacore (2002) propuseram um modelo baseado em avaliações realizadas por especialistas "disfarçados de clientes" onde tais especialistas exercem experiências de consumo e relatam tais experiências. Os autores recomendam que a avaliação seja executada por pelo menos quatro especialistas, que ao experimentarem os serviços prestados pela organização, executam simultaneamente suas avaliações. Segundo estes autores, este modelo, além de prático, é barato e promove resultados satisfatórios, sendo suas principais características:

a) Classifica atributos em três níveis:

- Básico/essencial (qualificador)

- Ganhador de pedidos

- Atrativos

b) Utiliza especialistas em qualidade que simulam a "aquisição do serviço" e os mesmos avaliam durante o "consumo" do serviço (os autores sugerem quatro a cinco especialistas).

c) Trata os resultados de forma "probabilística".

d) Classifica a organização conforme esquema mostrado na Figura 7. 


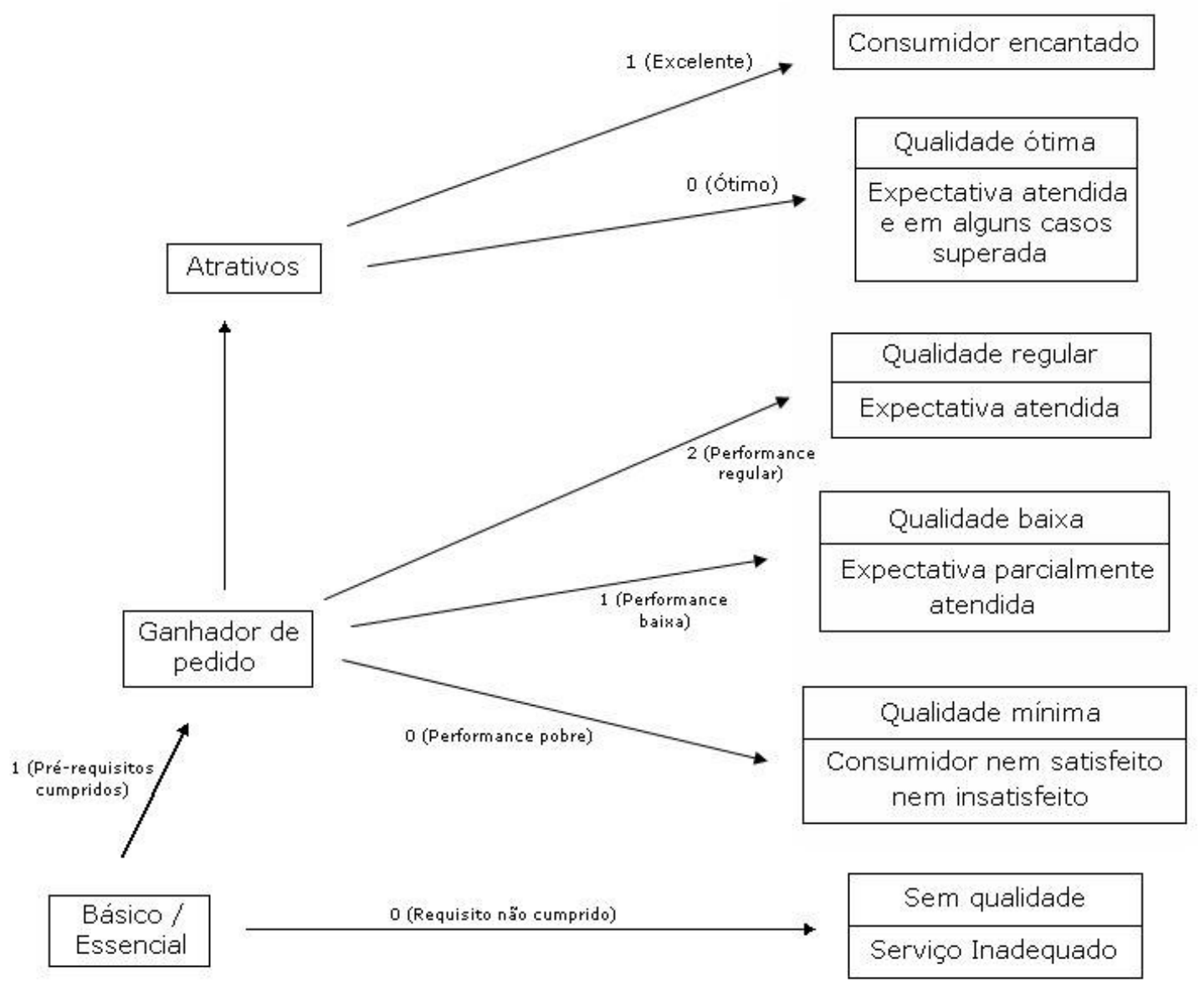

Figura 7 - Modelo de Erto e Vanacore (2002)

\subsubsection{A Técnica do Incidente Crítico de Bob Hayes}

Hayes (2001) afirma que "a medição das reações dos clientes está se tornando um elemento importante no movimento de Qualidade das organizações americanas”. Cita como exemplo, o Prêmio Nacional da Qualidade Malcolm Baldrige, outorgado anualmente para empresas americanas que demonstram altos padrões de práticas empresariais, inclui sete categorias pelas quais as empresas são julgadas. Destas sete categorias, aquela com maior peso é a satisfação do cliente. Hayes (2001) afirma que 
nesta categoria as empresas são julgadas com base em seus conhecimentos das necessidades e expectativas de dos clientes, da gestão do relacionamento com os clientes, dos métodos para determinação da satisfação de clientes, dos resultados da satisfação do cliente e por fim, as comparações do grau de satisfação dos seus clientes com o de seus concorrentes.

Segundo Hayes (2001), o conhecimento das percepções e reações dos clientes pode aumentar em muito as possibilidades das empresas no que tange à tomada de decisões estratégicas. O autor alerta sobre a importância dos instrumentos de medição destas percepções serem adequados. "Se esses instrumentos forem mal desenvolvidos ou representarem de forma inexata as opiniões dos clientes, as decisões tomadas a partir destas informações podem ser prejudiciais ao sucesso da organização”.

O modelo de Hayes (2001) propõe o monitoramento de satisfação do cliente em duas etapas. Na primeira etapa utiliza a técnica dos Incidentes Críticos que é uma sistemática que resulta em um relacionamento hierárquico entre os incidentes críticos, os itens de satisfação e as necessidades dos clientes, ou seja, as dimensões da qualidade, conforme representado na Figura 8 . Segundo o autor, a principal vantagem que a Técnica dos Incidentes Críticos possui em relação aos demais instrumentos é a de definir as necessidades do cliente através do próprio cliente; a Voz do Cliente é genuinamente utilizada. 


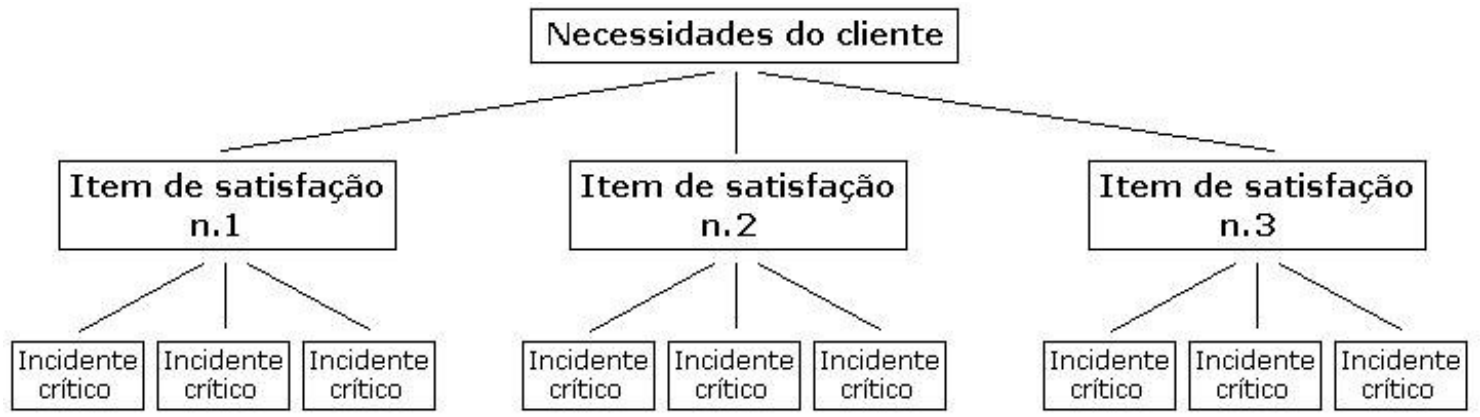

Figura 8- Relacionamento hierárquico entre Incidentes Críticos, Itens de Satisfação e Necessidade do Cliente

Fonte: Rotondaro, 2002 (adaptada)

Um incidente crítico é um exemplo específico do serviço ou produto que indica um desempenho positivo ou negativo do fornecedor, tal como foi percebido pelo cliente. $\mathrm{O}$ exemplo positivo é aquele que o cliente gostaria de desfrutar toda vez que recebesse o serviço ou comprasse o produto. $\mathrm{O}$ oposto, o exemplo negativo, é aquele que o desagradaria.

O incidente crítico deve possuir certas características para que possa ao final da sistemática traduzir corretamente as necessidades dos clientes, ou seja, as dimensões da qualidade. Ele deve ser:

a) Específico: descreve uma única característica do serviço ou produto;

b) Claro: todos devem entender da mesma maneira, não pode ser ambíguo;

c) Concentrado no comportamento do prestador do serviço; 
d) Concentrado no adjetivo específico que descreva o serviço ou produto.

A elaboração dos incidentes críticos é realizada em dois passos: no primeiro passo os clientes são entrevistados para o levantamento de informações específicas a respeito do produto ou serviço; no segundo passo essas informações coletadas são agrupadas por afinidade em vários conjuntos que definirão um item de satisfação e finalmente o conjunto de itens de satisfação afins refletirão uma dimensão da qualidade.

No segundo passo dos Incidentes críticos, Hayes (2001) recomenda proceder conforme a seguir:

a) Os incidentes críticos devem ser revisados e reescritos de maneira clara, sem, no entanto, modificar o conteúdo da frase;

b) Os incidentes críticos devem ser agrupados por afinidade;

c) Dos incidentes críticos obtidos, retirar $10 \%$ para que no final se confirmem os agrupamentos;

d) O agrupamento por afinidade deve ser realizado por uma pessoa, considerada o primeiro juiz, e confirmada por uma segunda pessoa, considerada o segundo juiz; O autor considera aceitável um índice de concordância entre os juízes da ordem de $80 \%$

e) A idéia central de cada agrupamento define um Item de Satisfação;

f) O conjunto dos itens de satisfação afins define uma necessidade do cliente ou dimensão da qualidade. 
De posse dos itens de satisfação, prepara-se o questionário de pesquisa, que depois de aplicado junto aos clientes deve ser verificado quanto a sua confiabilidade. Para tanto, Hayes (2001), sugere alguns métodos estatísticos, como regressão linear e método de divisão pela metade.

O autor não faz considerações sobre determinação de amostras e representatividade dos resultados para fins de generalização para o universo de clientes de uma determinada empresa. 


\section{METODOLOGIA}

\subsection{MÉTODOS APLICADOS}

Este capítulo apresenta os métodos de pesquisa utilizado no presente trabalho, a justificativa de sua utilização e a estrutura dos métodos adotados. Também são apresentados neste capítulo os pressupostos e o instrumento de coleta de dados.

De acordo com Nakano e Fleury (1996), o pensamento científico possui duas formas básicas: a indução, baseada na evidência empírica e a dedução, esta última baseada na lógica. Pela forma da indução, as conclusões de um processo de pesquisa são obtidas a partir de observações empíricas em um processo que vai de uma pressuposição até a conclusão, utilizando-se de um conjunto de fatos como elemento básico para se gerar uma teoria. Na forma da dedução, as conclusões são obtidas a partir de raciocínio lógico, utilizando-se de princípios e leis das teorias formuladas para entender os fenômenos observados. Segundo estes autores, as pesquisas devem contemplar uma fundamentação teórica, a qual deve servir como referência para o fenômeno estudado e uma parte prática, caracterizada pela coleta de dados, criatividade e percepção da relevância dos dados coletados.

Para Bryman (1995), o processo de teoria é cíclico e pode ser representado pela Figura 9. 
Fases Processos

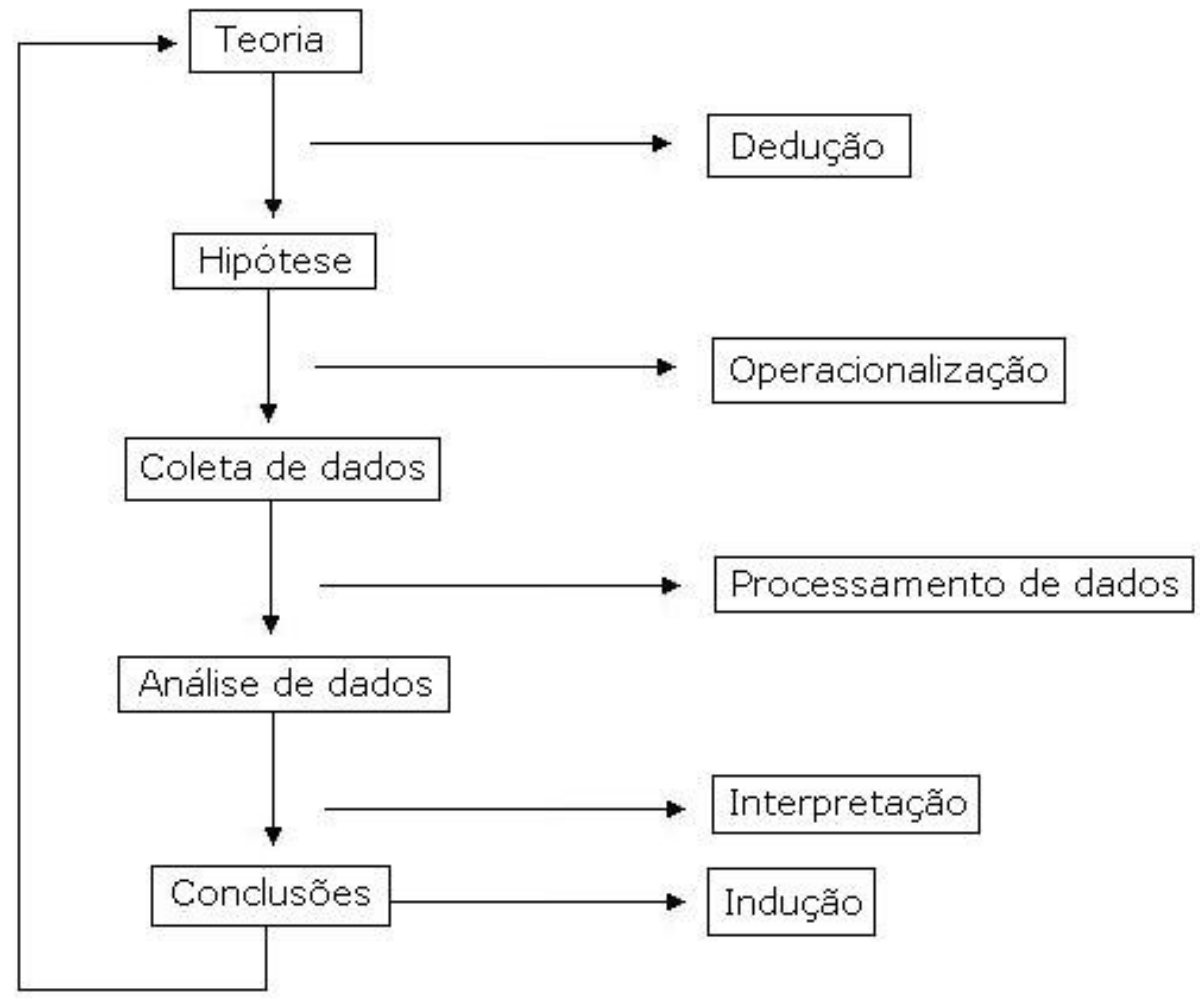

Figura 9- O método de Pesquisa de Bryman (1995)

Ghaury, Gronhaug e Kristianlund (1995) ressaltam que o processo científico de pesquisa deve ter como ponto de partida a definição do problema a ser estudado. O problema da pesquisa vai influenciar todas as outras etapas do processo de desenvolvimento de uma pesquisa científica como, por exemplo, o método a ser utilizado, as teorias que ajudem a explicar o problema, a amostragem e forma de coleta de dados, a análise dos dados coletados e as conclusões e recomendações. Para estes autores, os problemas de pesquisa correspondem às questões que sinalizam lacunas em 
determinado campo do conhecimento. As questões devem apontar para fenômenos problemáticos, eventos que desafiam as idéias já concebidas e aceitas pelo meio científico ou mesmo idéias atuais que se submetem a novos questionamentos.

Thiollent (1994) afirma que se devem analisar as características dos vários métodos disponíveis, suas potencialidades e limitações. De acordo com este autor, a metodologia deve auxiliar o pesquisador a se orientar, tomar decisões apropriadas e selecionar conceitos, técnicas e dados adequados.

Nakano e Fleury (1996) apresentam os principais métodos de pesquisa utilizados no campo da Engenharia de Produção, separando-os em dois grupos: a pesquisa quantitativa e a qualitativa. Os autores afirmam que os métodos quantitativos caracterizam-se pela busca de solução de um problema através de aspectos da realidade, devendo possuir rigor metodológico, hipóteses fortes e ainda incluir conceitos que possam ser medidos, de forma a possibilitar a geração de conclusões que permitam generalizações e replicação de resultados.

Malhotra (2001) afirma que a pesquisa quantitativa é a modalidade na qual variáveis pré-determinadas são mensuradas e estão na forma numérica. Geralmente utiliza cálculos com diversas técnicas estatísticas. Sua característica é o enfoque nos fatos reais, buscando a obtenção de explicações sobre inúmeros aspectos da realidade. Dentre os métodos quantitativos, os autores indicam a pesquisa experimental e o levantamento estatístico de dados (survey). 
Já os métodos qualitativos, segundo Nakano e Fleury (1996), são métodos interpretativos que exigem uma profunda compreensão do contexto da situação estudada. Para Malhota (2001), a pesquisa qualitativa é a modalidade na qual os dados são coletados através de interações sociais e avaliados subjetivamente pelo autor da pesquisa, focalizando os fenômenos contemporâneos. Fundamenta-se em amostras reduzidas que oferecerão uma compreensão intuitiva do contexto do problema, sendo exemplos deste grupo, o estudo de caso e a pesquisa-ação.

De acordo com Yin (2004), a escolha da estratégia mais adequada a ser adotada deve ser orientada por três critérios relevantes: o tipo do problema de pesquisa a ser estudado, o nível de controle exercido pelo pesquisador sobre o comportamento dos eventos a serem analisados e a relação entre enfoque no contemporâneo versus fenômeno histórico.

\subsection{ESCOLHA DO MÉTODO DE PESQUISA}

Nesta dissertação, optou-se por mesclar estratégias de pesquisa qualitativas e quantitativas para um adequado tratamento do problema proposto. 


\subsubsection{Estratégia de pesquisa quantitativa: survey}

Para a etapa quantitativa utilizou-se o método survey que, de acordo com Bryman (1995), tem por objetivo a descrição de eventos através da coleta de dados estruturados, seja através de questionários de pesquisa ou de entrevistas. O método permite a participação de um grande número de participantes e caracteriza-se pela ausência de intervenção do pesquisador.

Forza (2002) afirma que o survey contribui para o conhecimento geral de uma área de interesse, envolvendo a coleta de informações de indivíduos por meio de questionário ou entrevistas sobre suas atividades ou sobre si mesmos. Como ponto fraco do método, tem-se a dificuldade de aprofundamento em questões específicas pela distância com o objeto da pesquisa.

Filippini (1997) descreve o survey como um termo utilizado para coleta de dados, informações e opiniões de um grupo grande de unidades, possuindo três objetivos:

a) Investigação, com a finalidade de determinar quais conceitos são relativos a determinado fenômeno e como medi-los ou para descobrir novas dimensões do mesmo fenômeno;

b) Confirmação, com a finalidade de testar uma nova teoria, buscando relações entre causas e efeitos das variáveis;

c) Descrição de eventos ou opiniões de um grupo de pessoas. 
Forza (2002) descreve três tipos básicos de pesquisa baseada em survey:

a) Exploratória, aplicável quando a pesquisa ainda está em fase embrionária, havendo ainda uma necessidade de melhor entendimento e mensuração de conceitos; nesta fase não se tem um modelo teórico desenvolvido;

b) Explanatória, aplicável quando o conhecimento de um fenômeno é discutido dentro de uma base teórica ou estrutura conceitual bem definida;

c) Descritiva, aplicável quando o objetivo é entender a relevância de um fenômeno.

Utilizando-se dos fundamentos acima, esta pesquisa pode ser classificada como explanatória, visto que pretende discutir o fenômeno a partir de uma estrutura conceitual definida, mas também tem um caráter descritivo, pois também pretende descrever as práticas de mercado.

Para a realização do survey, foi preparado um questionário de pesquisa e o mesmo disponibilizado em um sítio da internet, onde as empresas pesquisadas puderam respondê-lo on line. Para tanto foi utilizado um software livre, o PHP Surveyor V0,98.

\subsubsection{O Software da pesquisa}

Para a realização da pesquisa de campo, o autor utilizou-se de um software livre, o PHPSurveyor V0.98., que pode ser obtido fazendo download do sítio http://sourceforge.net/projects/phpsurveyor/. O programa foi instalado no sítio de propriedade do autor na URL http://www.iso9000.com.br/pesquisa. 
Basicamente, o software é constituído dos seguintes módulos:

a) Edição de questionários de pesquisa;

b) Cadastro de participantes da pesquisa;

c) Edição e envio de e-mails de convite, confirmação de participação e lembretes;

d) Gerenciamento de participação e de resultados.

\subsubsection{Edição de questionários de pesquisas}

O Software oferece vários modelos de formato de apresentação do questionário, variando cores, formato de letras, linhas divisórias, etc. Na preparação do questionário, é possível determinar a obrigatoriedade de respostas para perguntas individuais ou para todas (para uma pergunta cuja resposta é obrigatória, se a mesma não for respondida, o questionário não é enviado). O software ainda oferece vários tipos de respostas, os quais devem ser determinados na preparação do questionário, tais como “ múltipla escolha, data, escala de 5 pontos, escala de 10 pontos, etc". É possível também estabelecer vínculos entre questões do questionário, ou seja, dependendo da resposta a uma dada questão, algumas questões podem ser suprimidas para o pesquisado.

O módulo de edição permite testes do questionário e alterações até o momento que a pesquisa é ativada. A partir daí, o software não permite mais alterações no questionário de pesquisa. 


\subsubsection{Cadastro de participantes da pesquisa}

Os participantes da pesquisa devem ser cadastrados em banco de dados que requer, nome, sobrenome e e-mail, embora, somente o campo e-mail seja obrigatório. Caso os campos nome e sobrenome fiquem em branco, a única inconveniência é que nos $e$ mails enviados para convite, confirmação de pesquisa e eventual lembrete, obviamente tais nomes não aparecem, tornando tais e-mails impessoais. Para cada participante cadastrado, o software gera um número de identificação (ID), através do qual é possível gerenciar a participação do mesmo na pesquisa.

4.2.1.4 Edição e envio de e-mails de convite, confirmação de participação e lembretes

O Software possui um módulo de edição de e-mails tanto para convite e confirmação de participação do convidado na pesquisa, bem como para lembrá-lo do convite anterior, para aqueles que não tenham respondido.

O e-mail de convite pode ser enviado individualmente para cada participante ou em bloco, para todos cadastrados no banco de dados, o mesmo ocorrendo com o e-mail lembrete; este último, só é enviado para aqueles que não responderam a pesquisa, mesmo quando utilizada a opção de envio em bloco. O e-mail de confirmação de participação é enviado automaticamente a todos que responderam a pesquisa.

Para cada e-mail convite é gerado um "link" exclusivo, através do qual, o participante tem acesso ao questionário de pesquisa, via Internet. 
4.2.1.5 Gerenciamento de participação e de resultados

Sempre que um convidado participa da pesquisa, o software envia um e-mail para o pesquisador com todas as respostas do participante, abastece um banco de dados de respostas e muda o status do convidado no banco de dados de convidados. Desta forma, o software só aceita uma participação. Se o convidado tentar responder novamente a pesquisa, o link já estará desativado. Através do módulo de gerenciamento de resultados, é possível visualizar resultados individuais por participante, resultados consolidados de toda a pesquisa e resultados por perguntas.

\subsubsection{O Questionário de Pesquisa}

O questionário de pesquisa, Anexo A, foi subdividido em duas partes, comentadas a seguir:

Parte A: Informações gerais sobre a empresa

Nesta parte foram criadas perguntas com a finalidade de posicionamento da empresa pesquisada, contendo informações relacionadas a dados gerais como razão social, responsável pelo fornecimento de informações, certificações obtidas, certificadora e forma de negócio (business- to- bussines ou business- to- consumer). 
Parte B: Informações sobre como a empresa monitora a satisfação de seus clientes Nesta parte foram criadas perguntas específicas sobre o método adotado pela empresa, com a finalidade de possibilitar a identificação de modelos apropriados; foram incluídas, dentre outras, perguntas relacionadas ao método adotado, periodicidade da realização do monitoramento de satisfação do cliente, departamento responsável pelo monitoramento, departamento a quem a pesquisa é dirigida no cliente, forma de apresentação de resultados, ações tomadas com os resultados obtidos e melhorias implementadas no método.

Um pré-teste do questionário de pesquisa foi realizado junto a 13 empresas e todas elas declararam que não tiveram dificuldades para responder o questionário, considerandoo adequado. Em média, as empresas demoraram 8 minutos para responder o questionário.

\subsubsection{Amostra adotada}

Foram encaminhados convites aos responsáveis pelo Sistema de Gestão da Qualidade de todas as empresas com certificado ISO-9000 no estado de São Paulo cadastradas no banco de dados do Comitê Brasileiro da Qualidade da Associação Brasileira de Normas Técnicas ABNT (CB-25), base de acesso público, mediante pagamento de anuidade. O pesquisador está partindo do pressuposto de que empresas certificadas monitoram a satisfação de seus clientes. 
A escolha do estado de São Paulo é justificada pelo fato deste estado concentrar a grande maioria das empresas certificadas, além de que, pressupõe-se que as empresas instaladas neste estado são as mais inovadoras em termos de gestão da qualidade e, portanto, se existir algo diferente em termos de monitoramento de satisfação de cliente, é neste estado que a pesquisa poderá identificá-la. Por fim, devido a limitações orçamentárias e, prevendo a necessidade de custos com telefonemas de "follow-up" e, eventualmente de viagens, delimitamos geograficamente nossa pesquisa ao referido estado.

A base de dados do CB-25 da ABNT informa, no mês de junho de 2006, a existência de 4097 empresas com certificado ISO 9001-2000 no estado de São Paulo. Para cada registro da base de dados são informados a razão social da empresa, unidade de negócio certificada, endereço, contato (nome e $e$-mail do responsável pelo Sistema de Gestão da Qualidade), CNPJ, além de dados da certificação obtida, como nome da certificadora, escopo de certificação, número, emissão e validade do certificado.

Para a obtenção dos dados cadastrais, o autor acessou $100 \%$ dos registros, cada um deles constituindo uma página no sítio do CB-25. No entanto a base de dados mostrouse bastante pobre, com registros incompletos, duplicados e até mesmo triplicados. Alguns registros possuem apenas o nome da empresa certificada, impossibilitando o seu uso na presente pesquisa. Do total de registros existentes, foi possível utilizar 2983, ou seja, cerca de $73 \%$ dos registros existentes foram cadastrados no banco de dados do software de pesquisa. 
Enviados os e-mails convite, obteve-se um retorno (devolução) de 756 por endereço de e-mail inexistente. Assim, efetivamente, 2227 empresas receberam convite para participação na pesquisa.

A tabela 6 mostra um quadro resumo.

Tabela 6 - Quadro resumo da amostra

\begin{tabular}{|c|c|c|c|}
\hline $\begin{array}{c}\text { Número de } \\
\text { empresas } \\
\text { informadas no sitio } \\
\text { do CB-25 }\end{array}$ & $\begin{array}{l}\text { Registros } \\
\text { utilizáveis }\end{array}$ & $\begin{array}{c}\text { E-mails } \\
\text { retornados por } \\
\text { endereço } \\
\text { inexistente }\end{array}$ & $\begin{array}{c}\text { E-mails } \\
\text { efetivamente } \\
\text { enviados }\end{array}$ \\
\hline 4097 & $2983(72,8 \%)$ & $756(18,4 \%)$ & $2227(54,3 \%)$ \\
\hline
\end{tabular}

\subsubsection{Estratégia de pesquisa qualitativa: estudo de múltiplos casos}

A pesquisa qualitativa representa uma possibilidade para a geração do conhecimento científico, possuindo, segundo Bryman (1995), as seguintes características:

a) $\mathrm{O}$ ambiente é a fonte de informação e o pesquisador representa o instrumento fundamental;

b) Diversas fontes de dados são utilizadas durante o transcorrer da pesquisa;

c) Existe proximidade entre o fenômeno e o pesquisador. 
O estudo de caso é um dos modelos bastante utilizado na pesquisa qualitativa, e é uma estratégia de pesquisa adequada quando o pesquisador necessita estudar fenômenos com questões do tipo "como" e "por que", como também em casos onde o pesquisador não possui grande controle sobre os acontecimentos, que são os alvos do estudo a ser realizado (Yin, 2004). O estudo de caso é uma descrição e explicação abrangentes de inúmeros componentes de uma determinada situação. Nesta técnica, objetiva-se coletar e analisar casos sobre o tema em questão, sendo bastante utilizado em estudos organizacionais e gerenciais, auxiliando o incremento do conhecimento científico sobre um determinado tema (Babbie, 1999).

De acordo com Cooper e Schindler (2003), um estudo de caso é uma pesquisa empírica que analisa um fenômeno contemporâneo em seu contexto verdadeiro, principalmente quando não se possui um claro conhecimento do fenômeno.

Segundo Yin (2004), o estudo de casos apresenta cinco características principais que podem ser assim descritas:

a) As questões do estudo: são questões explicativas relativas ao estudo que tratam das relações operacionais ao longo do tempo; a tarefa a ser realizada é a identificação clara e objetiva da natureza das questões, que orientará o trabalho a ser realizado;

b) As proposições do estudo: as proposições podem ser formuladas para nortear o estudo, facilitando a tarefa referente a onde localizar as evidências do valor relevantes para a pesquisa; 
c) Unidade de análise: está relacionada com a clara definição do caso; a unidade de análise pode ser um indivíduo, um programa, um processo ou um estudo sobre uma determinada mudança organizacional;

d) Conexão entre dados e proposições: a relação entre as informações obtidas no estudo e as proposições apresentadas inicialmente na pesquisa fornecerá uma análise criteriosa do estudo de caso, possibilitando conclusões posteriores;

e) Critérios para a interpretação dos dados: as inter-relações e as análises são realizadas por analogia de situações e buscam responder as questões ou dúvidas iniciais do tipo "como" e "por que"; para que isso ocorra, o pesquisador deve, no primeiro momento, construir uma teoria sobre o estudo a ser realizado.

O Método Estudo de caso ainda pode ser único ou múltiplo. O estudo de caso único é oportuno quando se tem apenas um caso extremamente contundente, representando um experimento decisivo para o teste de uma teoria formulada adequadamente. $\mathrm{O}$ estudo de casos múltiplos deve atender à lógica da replicação dos casos e não da amostragem, pois, segundo Yin (2004), o objetivo de um estudo de caso não é representar uma amostra, sendo a meta do pesquisador difundir teorias e a generalização analítica e não relacionar freqüências para obter a generalização estatística.

Julgou-se adequado para o problema de pesquisa apresentado, o emprego da estratégia de múltiplos casos. 


\subsubsection{Critérios para seleção dos casos}

Partindo do modelo conceitual de Giese e Cote (2000) para o constructo "satisfação", o autor estabeleceu os seguintes critérios:

a) A freqüência de monitoramento de satisfação deve ser elevada, com a finalidade de ampliar a possibilidade de captá-la no momento em que a mesma ocorre; assim, o intervalo em que o monitoramento é realizado deve ser o menor possível;

b) Como a resposta está no domínio de um determinado foco, é intuitivo que a participação de profissionais de diversas áreas na preparação dos questionários de pesquisa seja útil no sentido de se determinar os focos de satisfação, bem como o envio dos questionários a diversos setores do cliente;

c) Outro critério a ser adotado será o tratamento estatístico do monitoramento; assim, empresas que declararam utilizar métodos estatísticos tanto para a amostragem como para validação de instrumento de pesquisa será candidata a uma possível visita.

A tabela 7 resume os critérios adotados e a quantidade de empresas que responderam ao questionário da pesquisa survey que atendem aos mesmos. 
Tabela 7 - Critérios para seleção de casos

\begin{tabular}{|lc|}
\hline \multicolumn{1}{|c|}{ Critério } & Quantidade de empresas \\
\hline 1: Frequiência: no mínimo a cada três meses & 132 \\
\hline $\begin{array}{l}\text { 2: Preparação de questionário por diversas } \\
\text { áreas }\end{array}$ & 250 \\
\hline $\begin{array}{l}\text { 3: Envio de Questionário a diversos setores } \\
\text { do cliente }\end{array}$ & 48 \\
\hline 4: Validação de instrumento de pesquisa & 82 \\
\hline 5: Tratamento estatístico de amostra e dados & 130 \\
\hline
\end{tabular}

Uma análise detalhada dos questionários respondidos na pesquisa survey evidenciou que 12 empresas atendem a todos os critérios acima. $\mathrm{O}$ autor realizou o estudo de casos em cinco delas, optando por empresas que atuam em mercados diferentes.

\subsubsection{Protocolo da pesquisa}

O protocolo de pesquisa adotado nas entrevistas realizadas nas cinco empresas foi composto de:

a) Seleção de possíveis empresas a serem visitadas; uma análise detalhada dos questionários respondidos na pesquisa survey evidenciou que 12 empresas atendem a todos os critérios estabelecidos no item 4.2.1.2;

b) Realização de contatos telefônicos junto ao responsável pela Gestão da Qualidade das empresas selecionadas, visando a explicar a pesquisa, seus objetivos e a solicitar uma visita para a condução da entrevista;

c) Escolha das cinco empresas para a realização da pesquisa; 
d) Realização das visitas e aplicação do questionário; as entrevistas foram conduzidas com os responsáveis pela Gestão da Qualidade, sendo executadas também verificações em documentos, procedimentos internos, resultados de pesquisa de satisfação de cliente realizadas pelas empresas, softwares utilizados, etc., utilizando-se do mesmo questionário de pesquisa aplicado no survey;

e) Registro de anotações complementares ao questionário de pesquisa, com o objetivo de documentar as particularidades das empresas analisadas;

f) Análise geral dos dados coletados. 


\section{RESULTADOS}

\subsection{RESULTADOS DA PESQUISA SURVEY}

A pesquisa de campo foi aplicada no mês de junho de 2006, junto às empresas caracterizadas no item 4.2.1.7 deste trabalho. A quantidade de empresas que responderam ao questionário foi de 423 , representando $18,4 \%$ das empresas que efetivamente receberam o convite. Seis empresas declararam operar apenas em sistema de negócio B2C e foram descartadas. Os resultados são apresentados a seguir. Deve-se ressaltar que para alguns itens do questionário, a totalidade de respostas ultrapassa o número de respondentes, visto que algumas perguntas permitiam mais que uma resposta.

\subsubsection{Perfil das empresas respondentes}

Além da certificação ISO 9000, 91 empresas informaram possuir outros tipos de certificação, sendo as mais citadas, ISO 14000, TS 16949, OHSAS 18001, SASMAC, TL 9000, dentre outras.

A maioria das empresas está localizada na Grande SP, mas encontramos na amostra empresas de diversas regiões do estado, principalmente aquelas mais industrializadas como Sorocaba, Campinas, São José dos Campos, etc. 
A tabela 8 mostra as áreas de atividades das empresas respondentes.

Tabela 8 - Áreas de atividades das empresas participantes da pesquisa

\begin{tabular}{|c|c|}
\hline Área de Atividade & Percentual \\
\hline Borrachas e produtos plásticos & $14 \%$ \\
\hline Construção Civil & $8 \%$ \\
\hline Equipamentos Elétricos & $9 \%$ \\
\hline Máquinas e Equipamentos & $11 \%$ \\
\hline Metais básicos e Produtos Metálicos & $19 \%$ \\
\hline Têxteis e Produtos derivados & $4 \%$ \\
\hline Produtos Químicos & $13 \%$ \\
\hline Papel e Produtos de Papel & $5 \%$ \\
\hline Serviços & $3 \%$ \\
\hline Outros & \\
\hline
\end{tabular}




\subsubsection{Respostas ao questionário}

5.1.2.1 A empresa realiza um monitoramento de satisfação de cliente?

Como mostra a Figura 10, 414 empresas afirmaram monitorar a satisfação de seus clientes e apenas uma declarou não realizar esta atividade, confirmando o pressuposto da pesquisa de que empresas com certificado ISO 9000 monitoram a satisfação do cliente. Ressalta-se que, como tais empresas detêm um certificado ISO 9000, pressupõe-se que seus métodos foram considerados adequados pela certificadora que concedeu tal certificado.

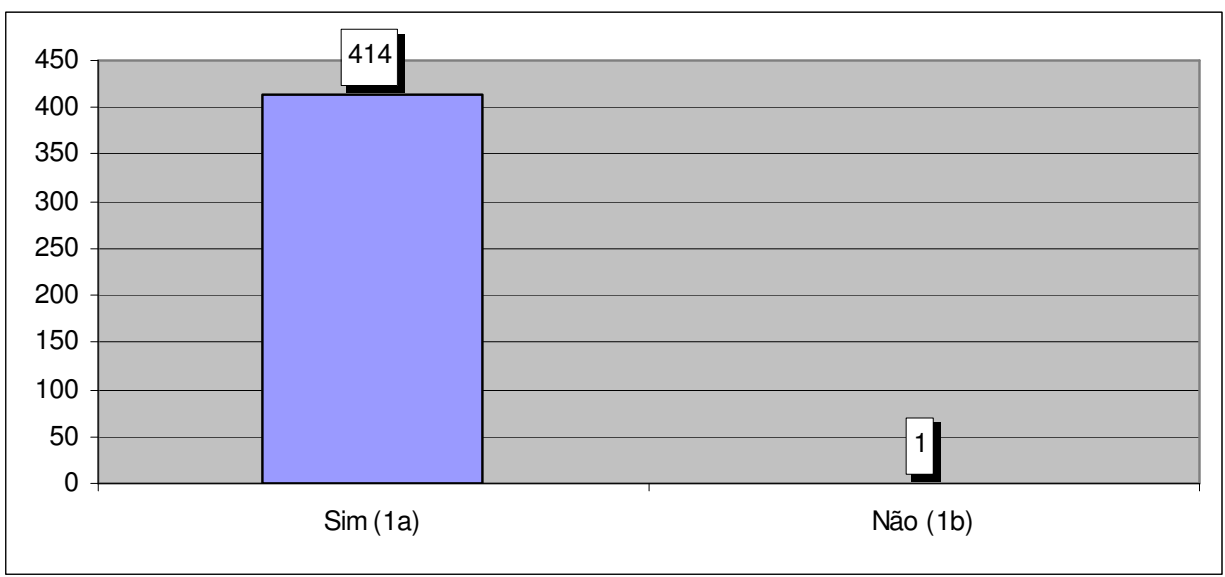

Figura 10 - Quantidade de empresas que declararam monitorar a satisfação de seus clientes

5.1.2.2 É utilizado algum modelo existente em literatura para preparação do questionário? 
Como mostra a Figura 11, a grande maioria das empresas (356) desenvolveu métodos próprios para monitorar a satisfação de clientes. As empresas que declararam recorrer a literatura para desenvolvimento de seu modelo não informaram quais são tais modelos, embora fosse solicitado no questionário. Ressalta-se que o fato da maioria das empresas não pesquisar o assunto pode ser um indício de que o assunto é tratado de forma superficial.

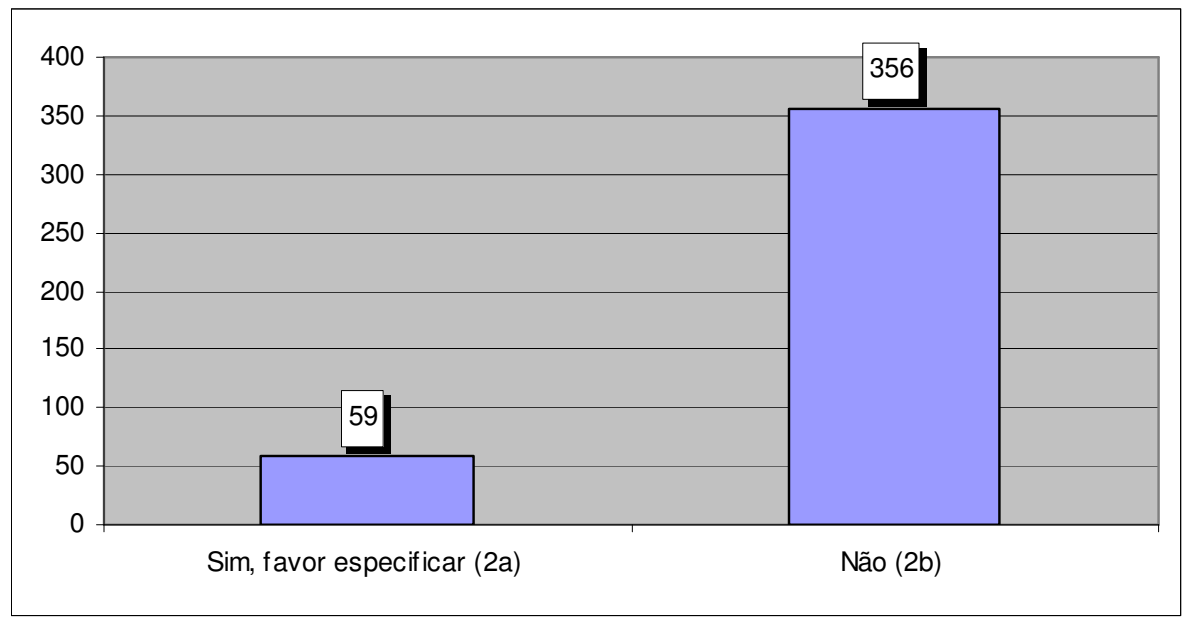

Figura 11 - Uso de modelo existente em literatura

5.1.2.3 Qual departamento/setor da empresa é responsável pelo monitoramento da satisfação dos clientes?

A Figura 12 mostra os departamentos responsáveis pelo monitoramento de satisfação do cliente, ficando a cargo do Setor de Qualidade, o maior número, seguido do Setor de Vendas. No item "outros", foram apontadas respostas como "diretor" e "administração de contratos", dentre outras. 


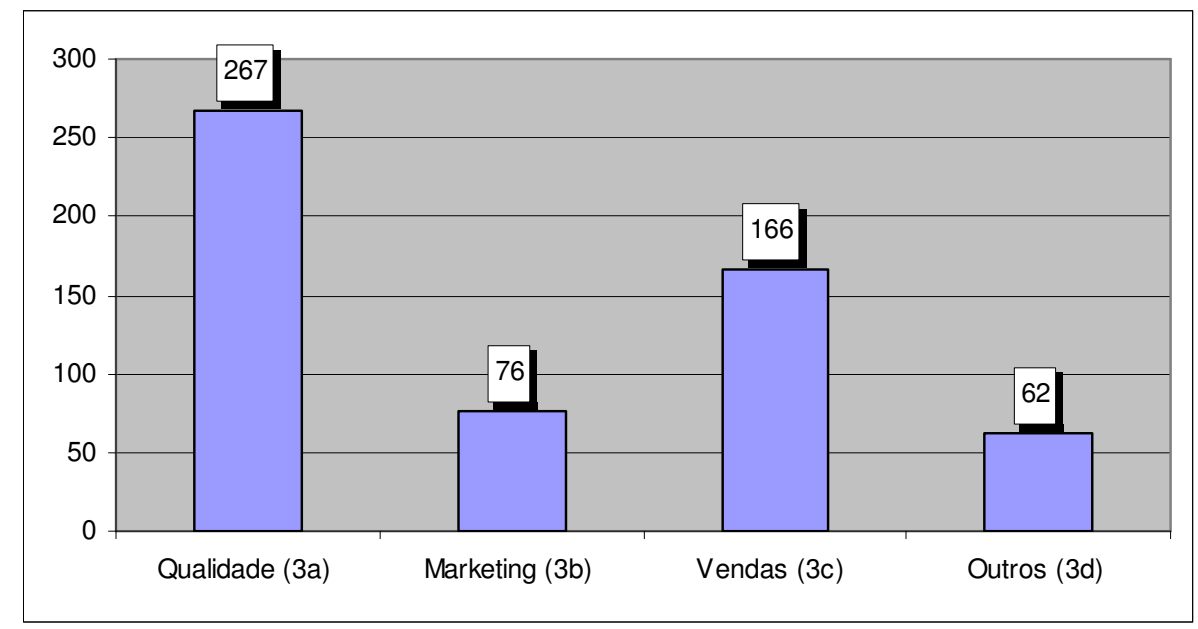

Figura 12 - Departamento responsável pelo monitoramento de satisfação do cliente

\subsubsection{Qual o método utilizado?}

A Figura 13 mostra os métodos adotados. A pesquisa de satisfação foi informada por 399 empresas. Pode-se observar, pelo número de respostas que a pesquisa de satisfação é combinada com os demais métodos, não sendo a única ferramenta utilizada pela maioria das empresas. Na maioria dos casos, a pesquisa de satisfação é combinada com avaliação de reclamações, seguida de indicadores fornecidos pelos próprios clientes, neste último caso, para empresas que têm como cliente montadoras e grandes auto-peças. Esta ferramenta está concentrada nas empresas que declararam possuir certificado ISO TS 16949. 


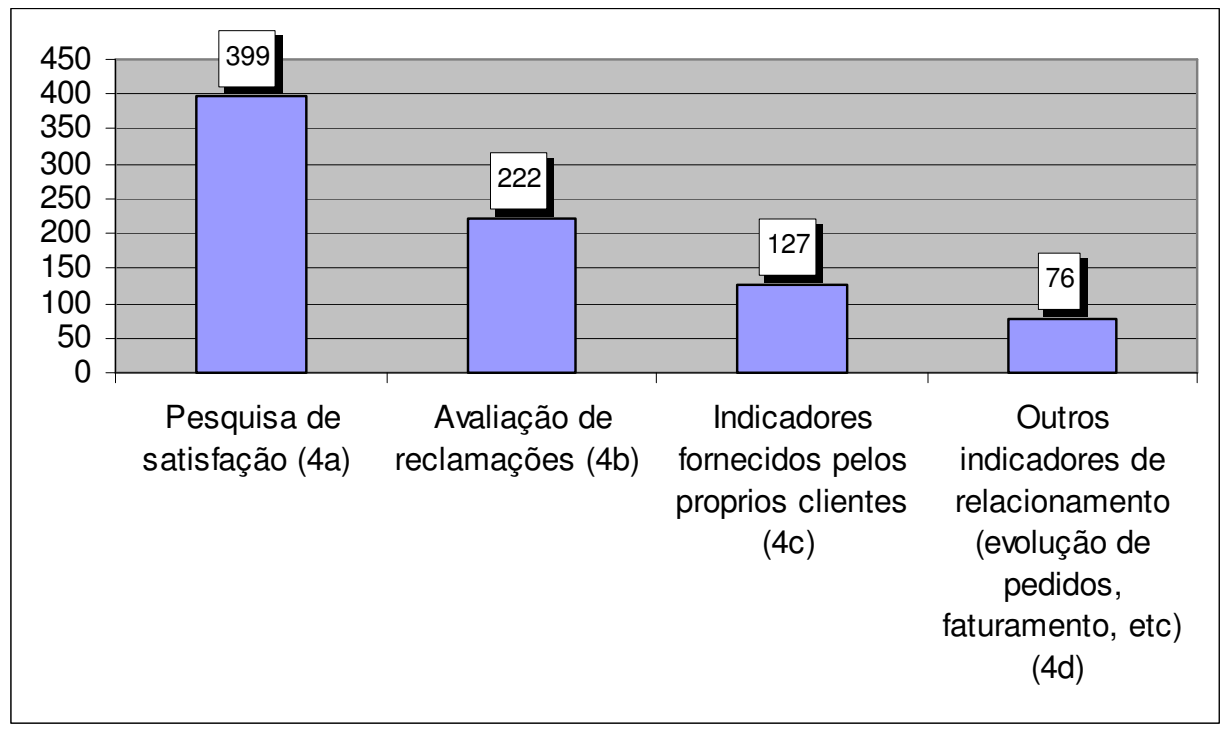

Figura 13 - Método Adotado

5.1.2.5 Com que frequiência é realizado o monitoramento de satisfação do cliente?

A Figura 14 mostra a frequiência com que as empresas monitoram a satisfação do cliente. Observa-se que a grande maioria realiza esta atividade em intervalos iguais ou maiores que seis meses, constituindo uma fragilidade dos métodos adotados, visto que, segundo a literatura, a satisfação tem duração definida e é enquanto ela ocorre, o momento mais adequado para mensurá-la, além do fato de que, nos casos em que se constata insatisfação, passou-se um longo tempo para a tomada de ações que pudessem revertê-la. 


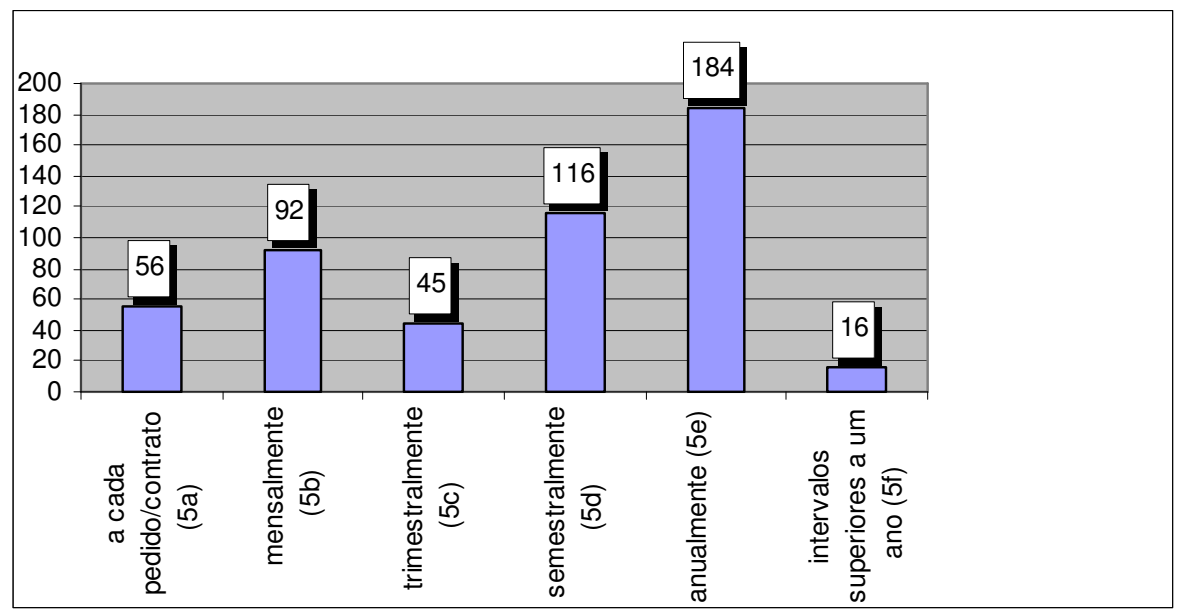

Figura 14 - Frequiência de monitoramento

\subsubsection{Como determina a amostra?}

A Figura 15 mostra os resultados para o critério de amostragem. Observa-se que pouco mais de $45 \%$ das empresas, pesquisam todos os seus clientes, $30 \%$ declararam utilizar critérios estatísticos e $26 \%$ declararam pesquisar os clientes mais importantes, sendo que nesta categoria, muitas empresas declararam pesquisar clientes " $A$ " da curva $A B C$ de faturamento.

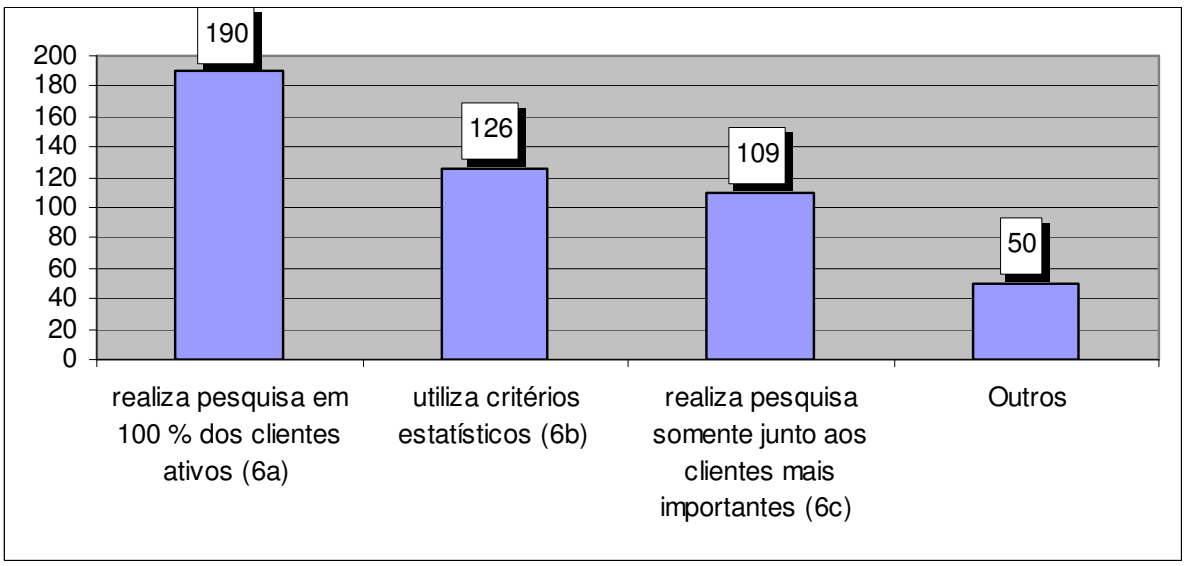

Figura 15 - Critérios de amostragem 
5.1.2.7 Qual o procedimento com relação a clientes que deixaram de comprar por um longo período?

Conforme mostra a Figura 16, aproximadamente $65 \%$ das empresas não incluem na amostra de pesquisa os clientes que deixaram de comprar por um longo período; tal fato pode gerar resultados falsos no Índice de satisfação, visto que empresas que deixam de comprar provavelmente o fazem por alguma insatisfação.

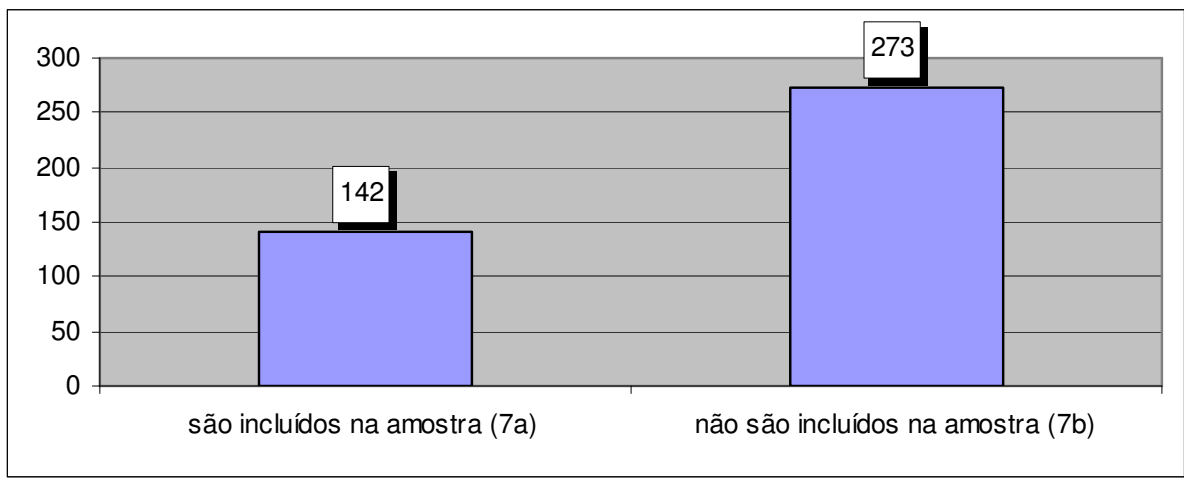

Figura 16 - Tratamento a clientes que deixaram de comprar

5.1.2.8 Como são preparados os questionários de pesquisa?

A Figura 17 mostra as respostas quanto à responsabilidade na preparação do questionário de pesquisa. Cerca de $59 \%$ dos respondentes declaram que o questionário de pesquisa é preparado por dois ou mais setores, constituindo um ponto positivo, visto que inclui opiniões diversas não se limitando a aspectos específicos. 


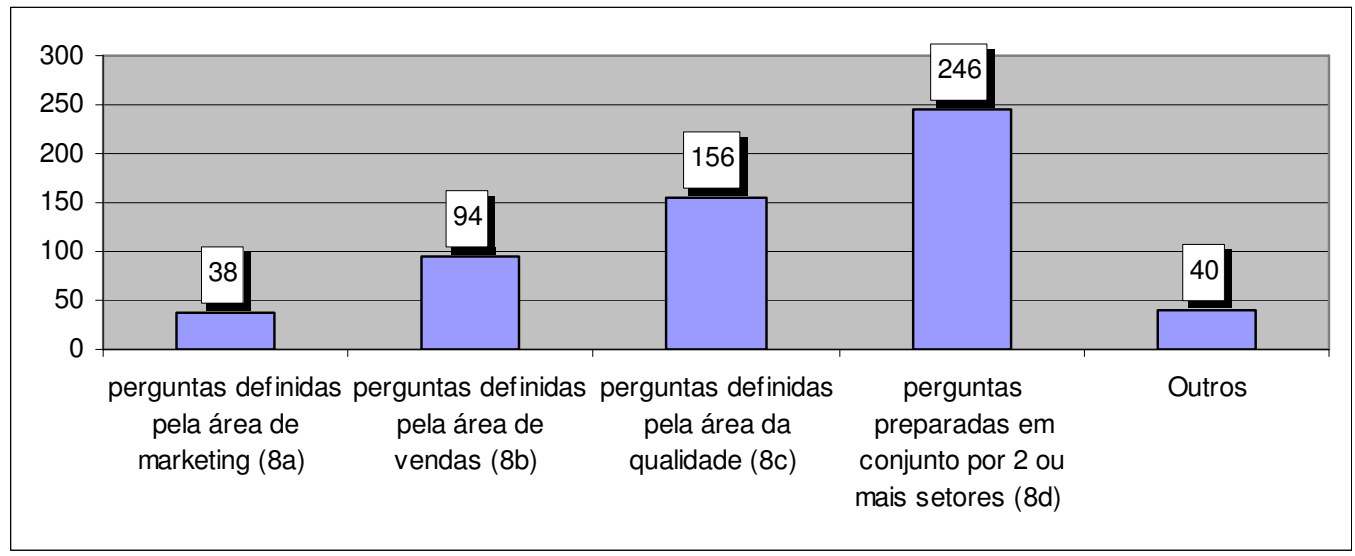

Figura 17 - Responsabilidade pela elaboração de questionário de pesquisa

\subsubsection{Na formulação das perguntas são considerados}

A Figura 18 mostra os aspectos pesquisados. 85\% das empresas declararam que incluem em seus questionários de pesquisa não só aspectos relacionados à qualidade do produto ou serviço comercializado, mas também os relacionados ao atendimento pré e pós-venda, constituindo um ponto positivo nos métodos adotados.

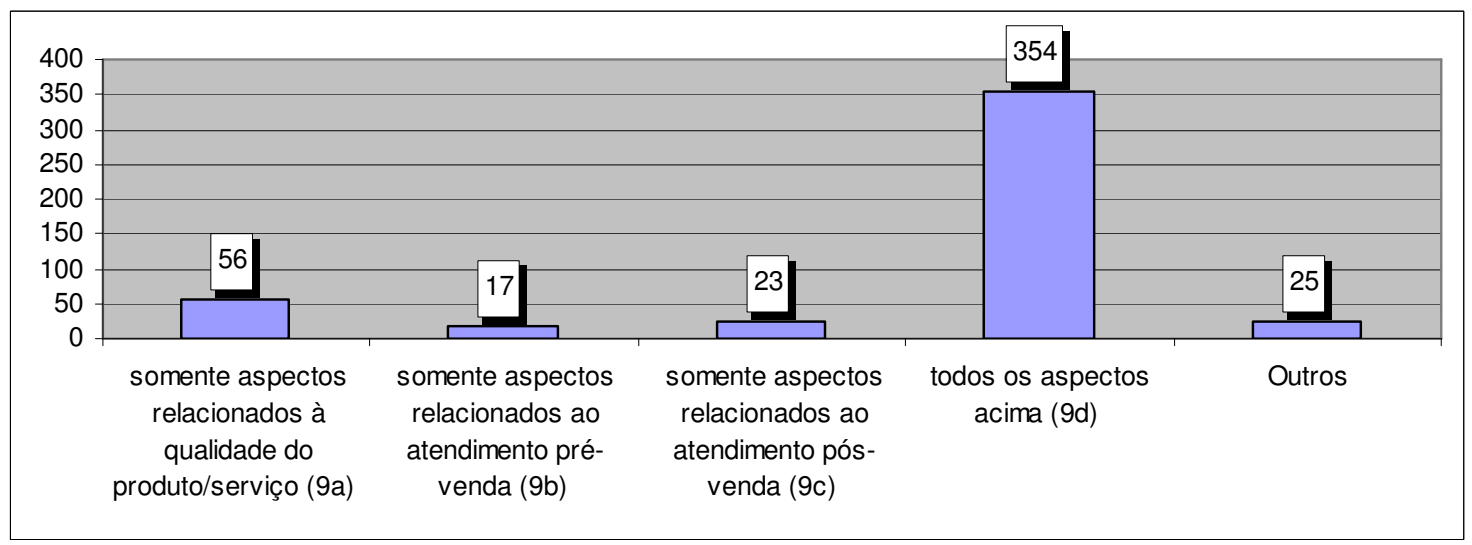

Figura 18 - Aspectos contidos nos questionários de pesquisa 
5.1.2.10 É realizado algum tipo de teste para validar o questionário de pesquisa?

De acordo com a Figura 19, apenas $19 \%$ dos respondentes declararam realizar algum tipo de teste para validar o questionário de pesquisa. Aqueles que informaram o tipo de teste executado declararam realizar apenas um teste tipo qualitativo (entendimento das perguntas); nenhum deles declarou realizar qualquer tipo de teste estatístico.

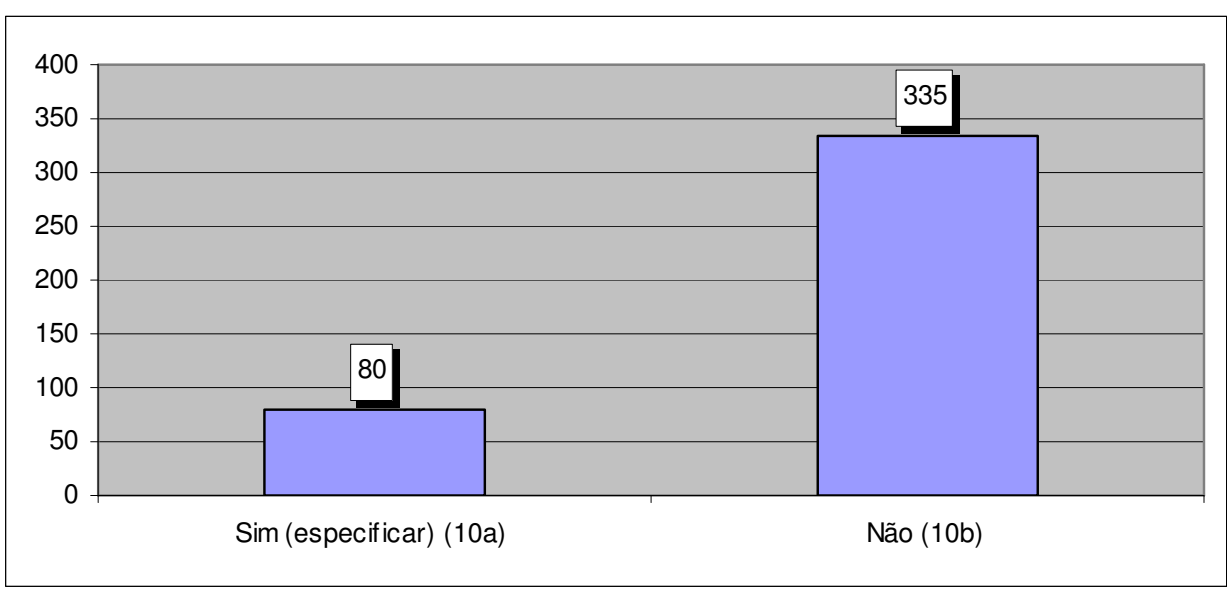

Figura 19 - Realização de testes de validação do instrumento de pesquisa

\subsubsection{A quem a pesquisa é endereçada?}

A Figura 20 mostra o endereçamento da pesquisa, sendo o comprador do cliente o principal destinatário (55\%), seguido do usuário do produto $(51 \%)$ e área da qualidade (31\%). Decorre dos percentuais que em boa parte das empresas pesquisadas, o instrumento de pesquisa não é enviado unicamente para um setor do cliente; as empresas que pesquisam diferentes setores do cliente têm maior probabilidade de mensurar com maior precisão o nível de satisfação do mesmo. 


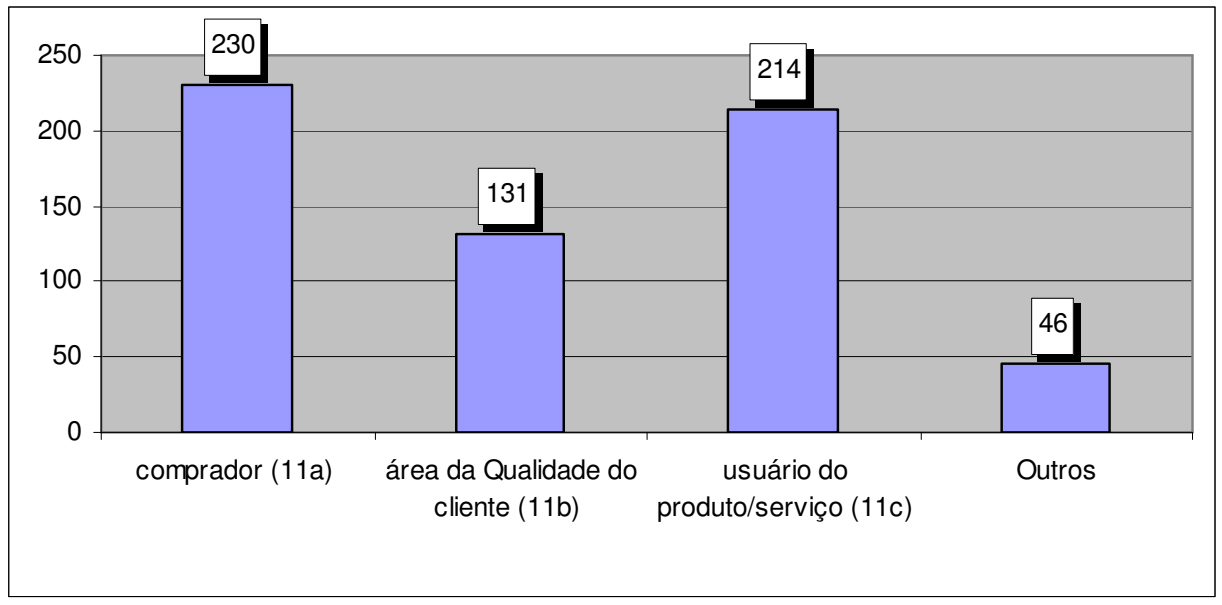

Figura 20 - Endereçamento da pesquisa

\subsubsection{Quem avalia os resultados da pesquisa?}

De acordo com a Figura 21, o setor de Qualidade das empresas pesquisadas é o maior responsável pela avaliação dos questionários de pesquisas, representando $77 \%$ das respostas, seguido pelas áreas de Vendas e Marketing. Também aqui, uma parcela representativa das respostas indica que é realizada avaliação conjunta por dois ou mais setores, representando um aspecto positivo.

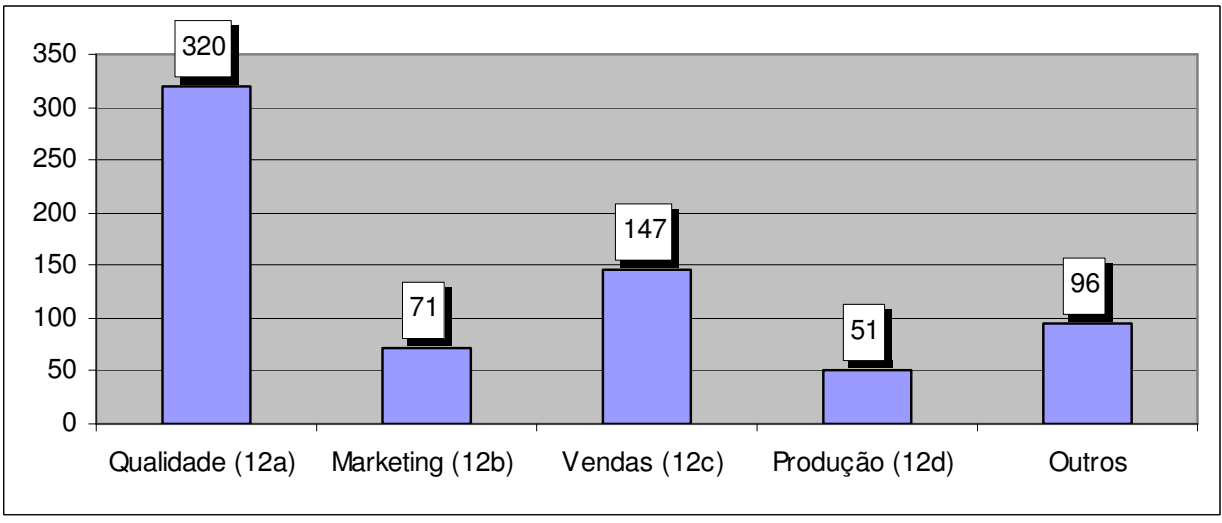

Figura 21 - Responsabilidade pela avaliação de questionários 
5.1.2.13 Como são apresentados os resultados da pesquisa para análise?

Como mostra a Figura 22, pouco mais de $75 \%$ das empresas pesquisadas criam relatórios com dados consolidados para análise. Caso estas empresas utilizem apenas valores médios, suas avaliações podem ficar comprometidas.

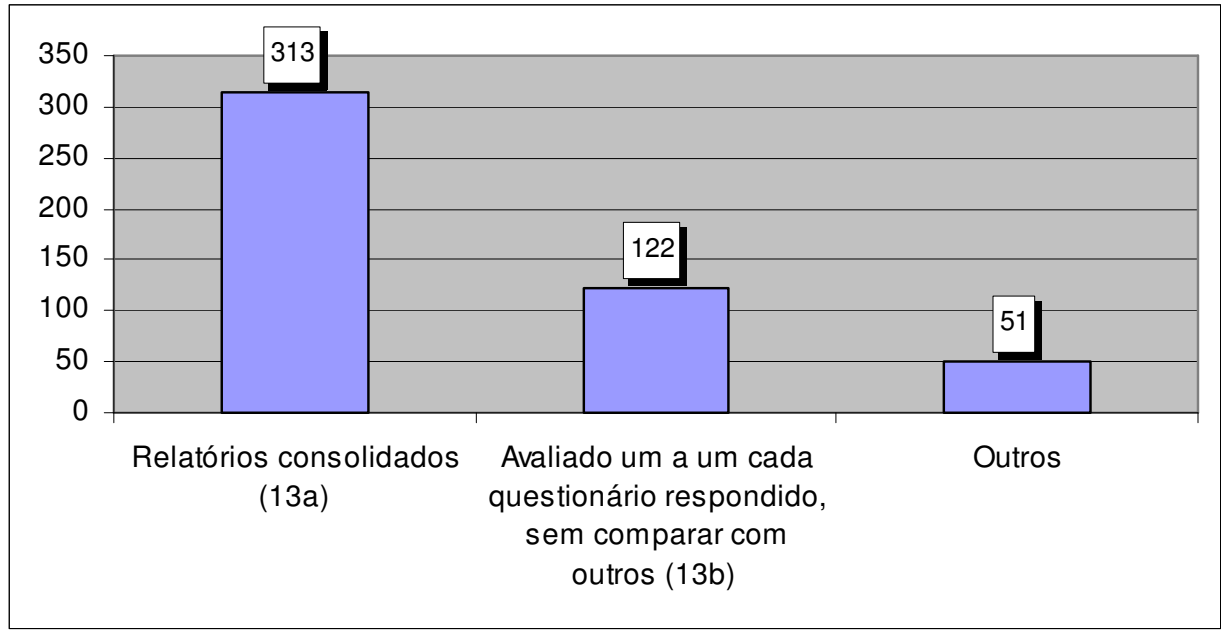

Figura 22 - Apresentação de resultados

5.1.2.14 A empresa estabeleceu um "Índice de Satisfação"?

A Figura 23 mostra a proporção de empresas que estabeleceram índices de satisfação, que são encontrados em mais de $87 \%$ dos casos. A existência de um índice permite o monitoramento da satisfação do cliente ao longo do tempo, indicando se ações efetuadas em função de resultados anteriores causaram impactos na satisfação. 


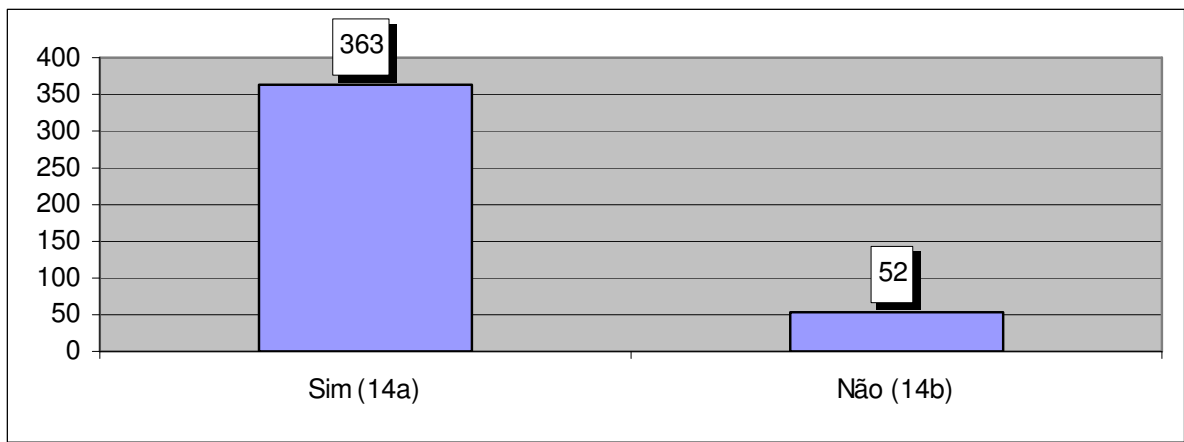

Figura 23 - Existência de índice de satisfação

5.1.2.15 Caso a empresa tenha estabelecido um Índice, existe alguma meta para o mesmo?

Igualmente à questão anterior, cerca de $85 \%$ das empresas pesquisadas estabeleceram metas para o seu índice de satisfação. A Figura 24 mostra as proporções encontradas.

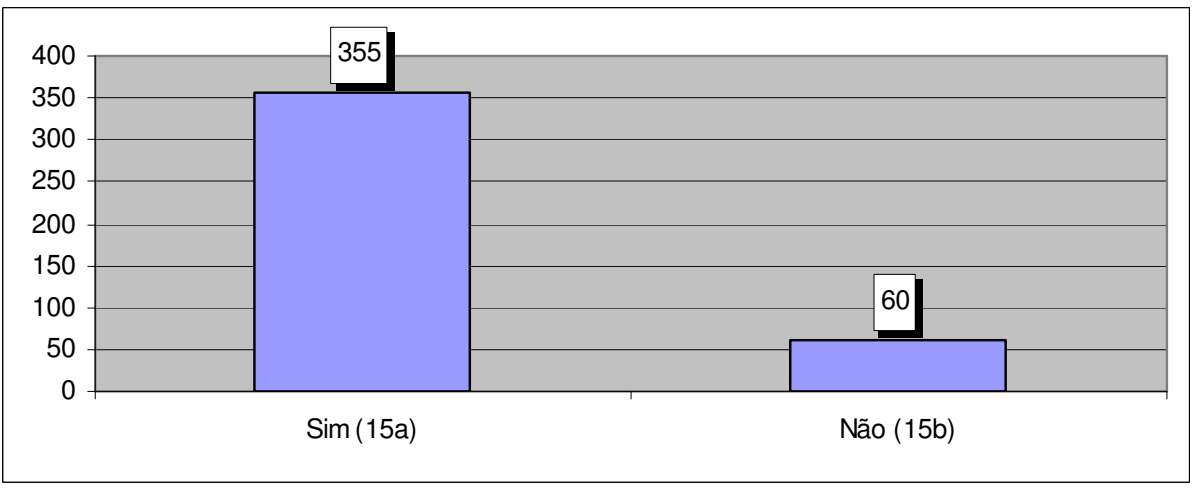

Figura 24 - Existência de metas para índice de satisfação 
5.1.2.16 São tomadas ações em função dos resultados da pesquisa?

A Figura 25 mostra as proporções para essa questão. Como nas duas questões anteriores, cerca de $88 \%$ das empresas declaram tomar ações em função dos resultados da pesquisa. Esta questão, juntamente com as duas anteriores sugerem que as empresas criaram índices de satisfação, estabeleceram metas para os mesmos e quando tais metas não são alcançadas, são tomadas ações corretivas no sentido de melhorar seu desempenho.

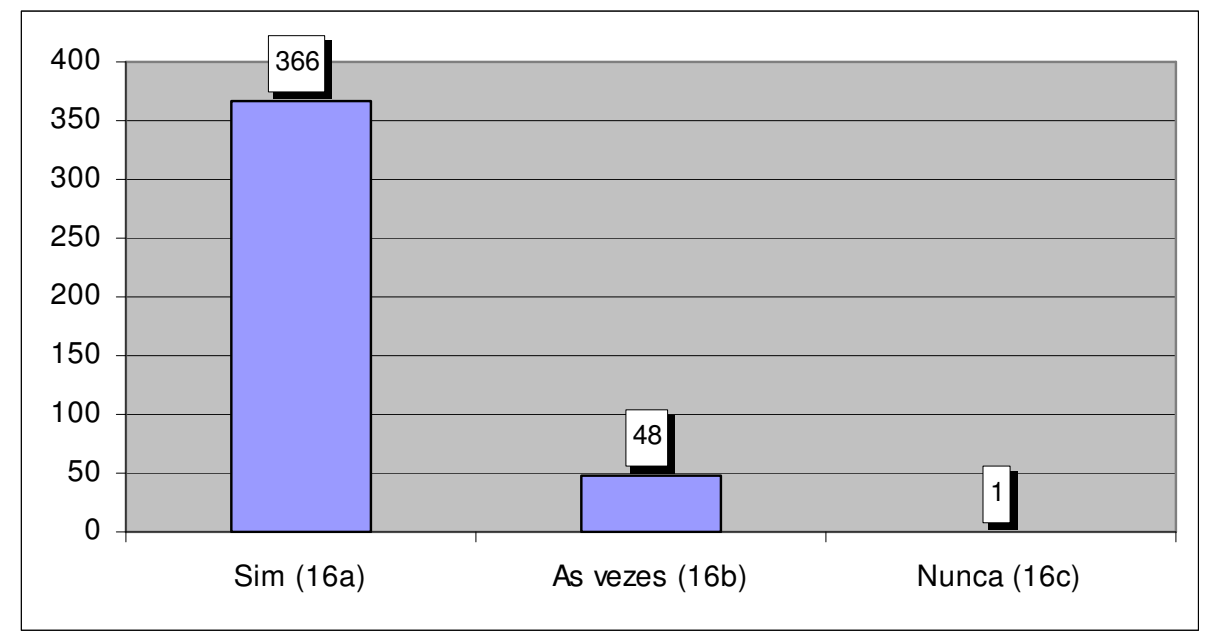

Figura 25 - Tomada de Ações em função de resultados da pesquisa

\subsubsection{Qual o retorno médio de questionários respondidos?}

A Figura 26 mostra os percentuais declarados de retorno por parte dos clientes do questionário de pesquisa, constituindo um fato surpreendente. De acordo com os respondentes, mais de $50 \%$ das empresas obtêm um retorno de mais de $60 \%$ dos 
questionários de pesquisa enviados a seus clientes. Analisando individualmente algumas respostas, o autor pode constatar que uma das empresas pesquisadas informa a seus clientes que cada questionário respondido gera uma doação financeira para entidades beneficentes, obtendo assim, um bom retorno.

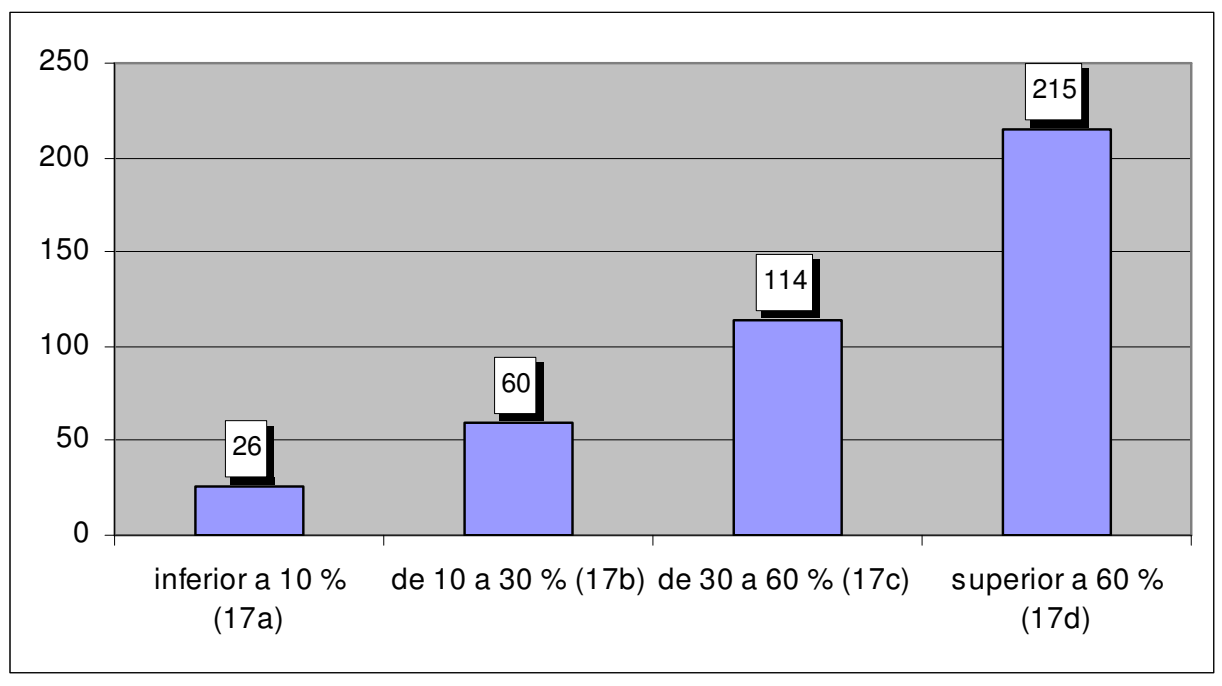

Figura 26 - Percentual de questionários normalmente respondidos

5.1.2.18 Questionários enviados e não respondidos pelos clientes:

A Figura 27 mostra as ações tomadas com relação a questionários não respondidos. Segundo as empresas pesquisadas, cerca de $58 \%$ delas insistem na resposta a sua pesquisa, realizando uma pesquisa verbal. 


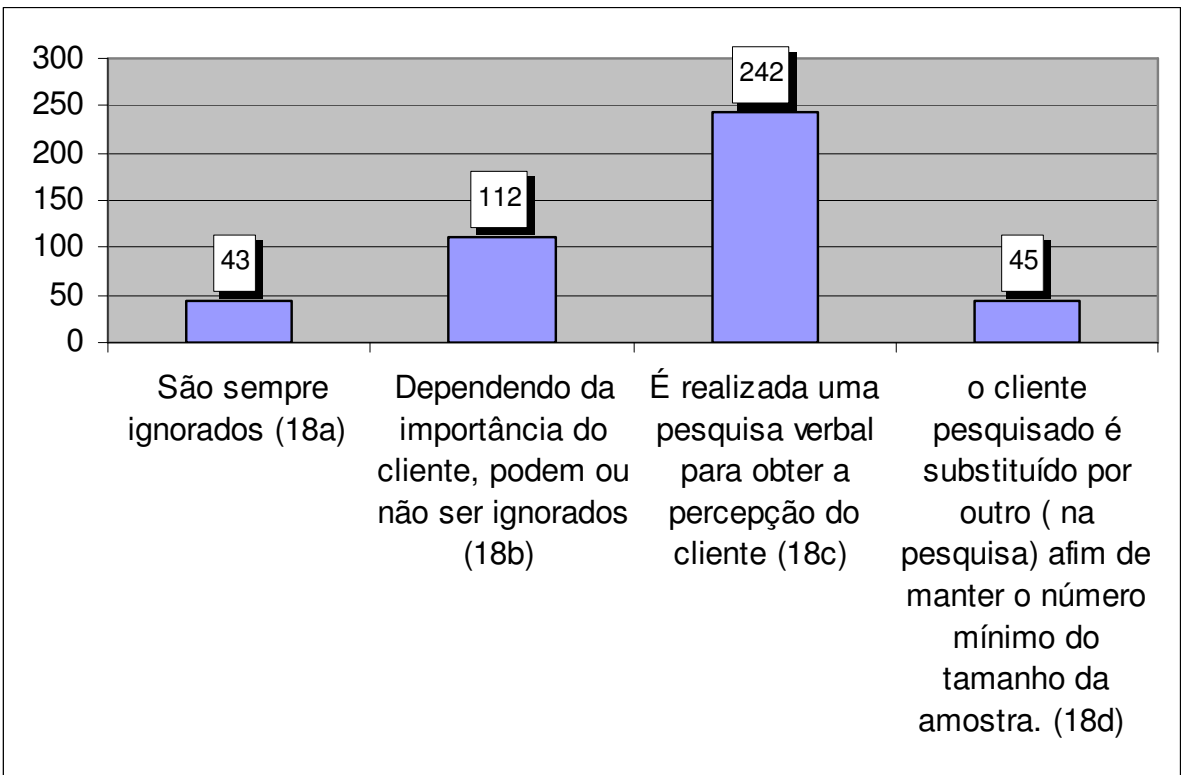

Figura 27 - Ações tomadas para questionários não respondidos

5.1.2.19 A empresa já implementou alguma melhoria no modelo de pesquisa?

A Figura 28 mostra as proporções de empresas quanto ao estabelecimento de melhorias nos métodos de pesquisa, correspondendo a cerca de $68 \%$ o número de empresas que declararam ter implementado em seus métodos. Para aquelas que declararam as melhorias efetuadas, destaca-se a reformulação dos questionários de pesquisa para melhorar a compreensão por parte de quem vai respondê-lo, o uso de ferramentas como software de pesquisa, estímulos para aumentar o retorno, como, por exemplo, a doação em dinheiro citada no item 5.2.18, esforços no sentido de medir a satisfação da alta direção do cliente, entre outros. 


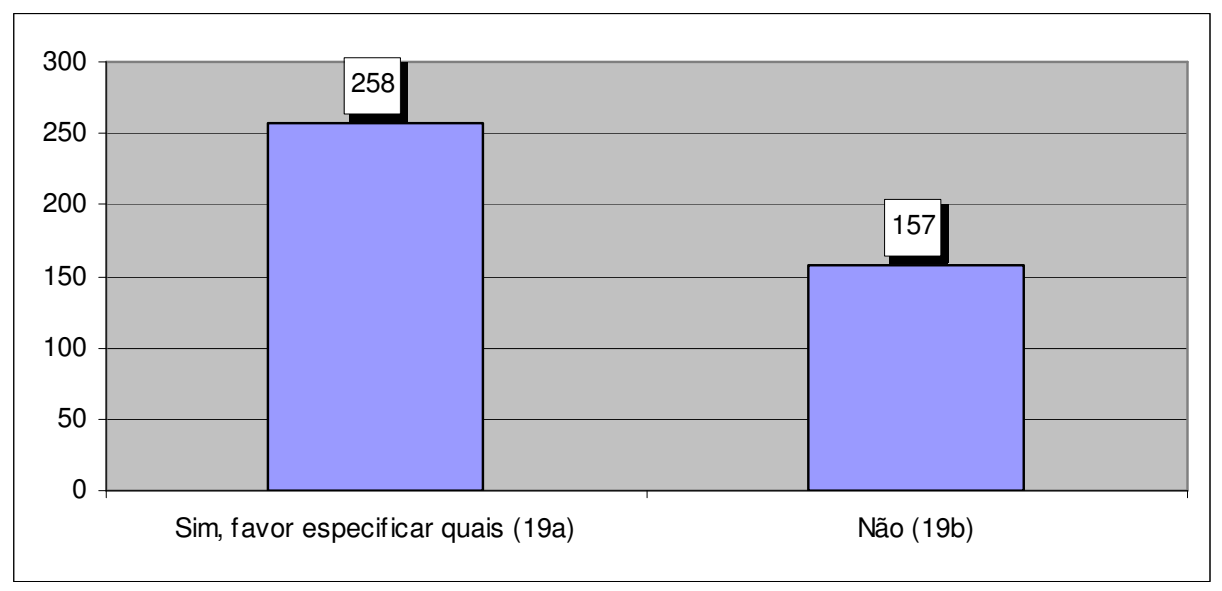

Figura 28 - Implementação de melhorias no método utilizado

\subsection{RESULTADOS DOS ESTUDOS DE CASO}

\subsubsection{Empresa "A"}

A empresa "A" é fabricante de embalagens secundárias (embalagem que não mantém contato com produto) para alimentos e medicamentos. Está situada na cidade de Barueri, Grande São Paulo, possui 243 funcionários e tem faturamento de cerca de R\$ 40.000.000,00 anuais. Têm cerca de 60 clientes ativos, os quais são fabricantes de medicamentos (para os quais produz cartuchos e bulas) e grandes produtores de alimentos industrializados, para os quais produz caixas e rótulos. A empresa tem as certificações ISO 9001-2000 desde o ano de 2002 e ISO 14001 desde 2005. Ambos os Sistemas são integrados e sua gerência está a cargo do Diretor Industrial que mantém uma equipe de cinco funcionários responsáveis pela operação do sistema integrado de gestão. 
O monitoramento formal da satisfação do cliente foi implementado no final de 2001 para atender aos requisitos da norma ISO 9001-2000. O método adotado desde então foi a pesquisa de satisfação, ficando a cargo da equipe de qualidade o gerenciamento do programa de monitoramento da satisfação do cliente.

A Equipe de Qualidade se reúne uma vez ao ano com representantes dos diversos setores da empresa para revisar os questionários de pesquisa.

Nesta revisão são considerados aspectos que se tornaram relevantes ao longo do período anterior, sugestões de clientes, reclamações cujos teores não estavam contemplados em pesquisa anterior. São preparados três questionários distintos:

a) Um para o processo de atendimento comercial, o qual inclui perguntas relacionadas aos serviços de pré-venda, desenvolvimento de produtos e apresentação de amostras prévias e preparação de contratos de fornecimento e pedidos de venda;

b) Um segundo questionário relacionado a todo o processo de gerenciamento de contratos, cobrindo aspectos de qualidade do produto, cumprimento de prazos, informações sobre andamento da fabricação e entrega;

c) Um terceiro relativo às atividades de pós-venda, incluindo questões relativas à resolução de problemas, agilidade na prestação de informações e apoio ao cliente na utilização do produto. 
Todos os clientes ativos são pesquisados ao longo do ano, utilizando o seguinte critério:

a) Realização de pesquisa mensal com cerca de $10 \%$ dos clientes, obtidos através de sorteio randômico; os clientes pesquisados em um determinado mês são excluídos dos próximos sorteios, desde que não ocorram situações, como declarado no item $b$;

b) Sempre que há uma reclamação de um determinado cliente considerada procedente, o mesmo é incluído na amostra do mês seguinte e considera que com esta sistemática pode avaliar se as ações tomadas em função de reclamação geram algum impacto na satisfação.

c) Embora, segundo o entrevistado, a empresa não tenha perdido nenhum cliente nos últimos três anos, o procedimento de monitoramento de satisfação do cliente prevê que se houver perda de cliente, deve-se preparar uma pesquisa específica para o caso, na tentativa de se obter informações sobre os motivos que geraram insatisfação a ponto do cliente deixar de comprar;

d) A empresa realiza uma "validação" interna dos questionários de pesquisa submetendo aos gerentes de departamentos que avaliam se as perguntas são claras e se as mesmas refletem todos os aspectos importantes do relacionamento com os clientes; não é realizado nenhum tipo de validação com base em respostas coletadas.

e) Os questionários são elaborados de forma estruturada e as respostas devem ser fornecidas em uma escala que varia de zero (muito insatisfeito) a dez (muito satisfeito). 
A equipe de qualidade realiza levantamento dos contatos do cliente junto aos diversos departamentos e posteriormente realiza a pesquisa por telefone.

O autor pôde acompanhar a execução de uma das pesquisas realizadas com o supervisor da embalagem de um cliente, indústria farmacêutica. Como a empresa tem número limitado de clientes e a pesquisa é realizada por telefone, o retorno é de $100 \%$.

No final de cada mês, todas as respostas obtidas são lançadas em planilha Excel e gerados gráficos de satisfação para cada item do questionário (média das respostas).

Alem disso, a empresa tem outra planilha com respectivos gráficos e evolução mês a mês do nível de satisfação para cada item. Os clientes pesquisados por motivo de reclamação contribuem para o cálculo da média, mas são destacados para fins de acompanhamento.

A empresa ainda estabeleceu um índice desejável de satisfação (média =9,5) e um nível mínimo de controle (média $=8,5$ ). Caso em determinado mês o nível mínimo não seja atingido, a empresa estabelece ações no sentido de elevar tal nível. Para tanto, todo esse monitoramento é apresentado à reunião gerencial, intitulada "REGER" que ocorre todo inicio de mês com o objetivo de analisar todos os indicadores estratégicos. 


\subsubsection{Empresa 'B"}

A empresa "B" é uma operadora de planos de saúde, planos odontológicos e benefícios (descontos na aquisição de medicamentos, serviços de "home care", palestras e cursos, dentre outros) na modalidade "auto-gestão". Não possui planos próprios e operam os planos e benefícios de seus clientes, grandes empresas da área de telecomunicações.

Tem sua sede na cidade de São Paulo, contanto com sucursais em Salvador, Rio de Janeiro, Campinas, Sorocaba e Bauru. Possui 290 funcionários e tem faturamento de cerca de $\mathrm{R} \$ 35.000 .000,00$ anuais, relativos a mensalidades e co-participação dos associados em programas de benefícios. Têm oito clientes, pessoas jurídicas, com os quais mantêm contratos de gestão de seus planos de saúde e atende cerca de 28.000 usuários, funcionários e familiares das empresas-cliente. A empresa tem as certificações ISO 9001-2000 desde o ano de 2005. O Sistema de Gestão da Qualidade é gerenciado pela área regulatória, que além de manter tal sistema também é responsável por todos os contatos com a Agência Nacional de Saúde e pela inserção das regras de negócio no sistema informatizado.

O monitoramento formal da satisfação de cliente foi implementado durante o processo de implantação da norma ISO 9001-2000 para atender aos requisitos de certificação. O método adotado desde então foi a pesquisa de satisfação, ficando a cargo do setor de telemarketing realizar as pesquisas, as quais são realizadas por telefone. 
Por ocasião da implantação de seu Sistema de Gestão da Qualidade, a empresa formou uma equipe com representantes dos departamentos de Gestão de Saúde, Cadastro, Administração, Contas Médicas, Contas Odontológicas, Benefícios, Comercial e Central de Atendimento. A equipe além de ser responsável pela implementação dos requisitos da norma em sua área de trabalho também foi responsável pela elaboração do método de monitoramento de satisfação dos clientes.

O foco dos questionários de pesquisa foi o serviço prestado pela empresa. Assim foram criados quatro questionários de pesquisa, a saber:

a) Questionário sobre a satisfação dos usuários quanto aos serviços de atendimento prestado pela empresa (informações gerais, solicitações de benefícios, liberação de senhas para realização de procedimentos pela rede);

b) Questionário sobre a satisfação dos usuários quanto aos serviços prestados pela rede de prestadores de serviços de saúde (médicos, clínicas, hospitais);

c) Questionário sobre a satisfação dos usuários quanto aos serviços prestados pela rede de prestadores de serviços odontológicos;

d) Questionário sobre a satisfação dos usuários quanto aos programas de benefícios oferecidos.

Todos os questionários foram adaptados da escala SERVQUAL de Parasuraman, Zeithaml e Berry (1988) para os serviços citados e a pesquisa é aplicada trimestralmente (um questionário a cada trimestre na ordem apresentada acima). 
A pesquisa é realizada por amostra aleatória, sendo selecionados cinqüenta usuários de cada empresa-cliente entre aqueles que utilizaram o serviço pesquisado no trimestre anterior. Os usuários são solicitados a responder a pesquisa em uma escala Likert de sete pontos. Os resultados são compilados e são fornecidos as médias e desvio-padrão.

A partir destes dados é calculado o erro da pesquisa através de fórmulas estatísticas e a pesquisa é considerada validada quando o erro é inferior a $+/-3 \%$. Caso o erro seja superior a este valor, o tamanho da amostra é aumentado em cerca de $30 \%$, novos cálculos são executados e este processo se estende até que o erro atinja o valor especificado.

Os valores da escala Likert são convertidos em percentuais e a empresa estabeleceu junto aos clientes um índice mínimo de satisfação que, se não atingido, ações devem ser tomadas no sentido de elevar tal índice na próxima pesquisa. Os dados são consolidados por cliente, apresentados aos diretores da empresa e levados ao representante do cliente (normalmente o Gerente de Recursos Humanos). O ponto negativo do método adotado é que a eficácia de eventuais ações somente poderá ser verificada no ano seguinte, visto que, para cada serviço é realizada uma única pesquisa.

No ano de 2006 está sendo realizado o segundo ciclo de pesquisa e o Responsável pelo Sistema de Gestão da Qualidade declarou que pretende implementar melhorias no método a partir de 2007. 


\subsubsection{Empresa "C"}

A empresa "C" é uma indústria metalúrgica, fabricante de peças para a "linha branca". Está situada na cidade de Bragança Paulista, Grande São Paulo, possui 108 funcionários e tem faturamento de cerca de $\mathrm{R} \$ 14.000 .000,00$ anuais. Tem como clientes os grandes fabricantes de fogões, geladeiras, lavadoras, etc. A empresa é certificada ISO 9001 desde a versão 1994 (primeira certificação em 1997), e está implementando os requisitos de Gestão Ambiental estabelecidos pela norma ISO 14001, com certificação prevista para março de 2007. A gerência do Sistema de Gestão da Qualidade é de responsabilidade do Chefe de Controle da Qualidade, também responsável pelo planejamento da qualidade dos produtos, realização de inspeções de recebimento, análise de dados do controle estatístico de processo (realizado pela produção) e inspeção final dos produtos fabricados.

O monitoramento formal da satisfação de cliente foi implementado durante a transição da norma ISO 9001 da versão 1994 para a 2000 (em 2002), com objetivo de atender aos requisitos da norma ISO 9001-2000. O método adotado foi a pesquisa de satisfação, ficando a cargo do próprio Chefe de Controle da Qualidade a execução das pesquisas, análise de dados e apresentação dos resultados à diretoria da empresa, que é composta de três sócios, sendo um deles responsável pelas atividades comerciais, o segundo pelas operações industriais e o último pela gestão financeira da empresa. 
A empresa criou um questionário único de pesquisa cobrindo todos os aspectos do relacionamento com o cliente, abrangendo as atividades comerciais, de produção e entrega e pós-venda. Para tanto, segundo o Chefe de Controle da Qualidade, partiram de vários modelos recebidos de fornecedores, que na ocasião também estavam em fase de implantação da ISO 9001-2000, fazendo as devidas adaptações à realidade da empresa através de reuniões com os diversos setores da empresa. Como resultado deste processo, gerou-se um questionário com 47 perguntas, separadas por área de relacionamento com o cliente, formando os seguintes blocos:

a) Atividades comerciais: perguntas relacionadas ao atendimento dispensado pela telefonista e equipe de vendas, envolvendo prontidão de atendimento, cortesia, competência, profissionalismo e flexibilidade nas negociações;

b) Atividades de desenvolvimento de projetos: perguntas relacionadas ao atendimento dispensado pela equipe de desenvolvimento, competência, atendimento às especificações, profissionalismo e grau de inovação dos projetos executados;

c) Atividades referentes às operações industriais e entrega: perguntas relacionadas à qualidade do produto, cumprimento de prazos, transporte e postura do pessoal de entrega nas instalações do cliente;

d) Atividades pós-venda: perguntas relacionadas à assistência técnica e atividades administrativas de cobrança.

O Questionário de pesquisa foi criado como um formulário do software Microsoft Word, e é encaminhado trimestralmente a todos os clientes através de correio 
eletrônico; embora seja enviado à área de qualidade do cliente, é solicitado que o responsável por tal área, replique o mesmo a todos os envolvidos. Segundo o Chefe de Controle da Qualidade, em média, há um retorno de $60 \%$ dos clientes e para cada cliente, em média, recebe respostas de três departamentos distintos.

As respostas ao questionário de pesquisa são fornecidas em escala Likert de 5 pontos e os resultados compilados por blocos, conforme descrito anteriormente, em termos de média simples. São divulgados em murais espalhados pela empresa, os resultados da última pesquisa e um gráfico indicando a evolução dos índices desde a sua implementação. A empresa declarou que o nível de satisfação tem sido considerado adequado e que, portanto, não houve até o momento necessidade de se implementar ações de melhoria. O menor nível de satisfação ocorreu no ano de 2004, ficando em 4,4 (em uma escala de 1 a 5) para as atividades industriais. Para as demais pesquisas todos os resultados foram superiores a 4,8 .

A empresa realiza ainda a cada seis meses uma reunião de análise crítica do Sistema de Gestão da Qualidade entre os diretores e o Chefe de Controle da Qualidade, ocasião em que os resultados da pesquisa são apresentados formalmente à direção.

\subsubsection{Empresa "D"}

A empresa "D" é uma indústria multinacional de origem americana, projeta e fabrica sistemas e componentes para automação industrial. Está situada na cidade de São 
Paulo e possui 173 funcionários. A empresa não quis declarar o seu faturamento. Têm vários segmentos de atuação, mas seus principais clientes são grandes indústrias química e petroquímica. A empresa é certificada ISO 9001 desde a versão 1994 (primeira certificação em 1999) e tem um programa informal de Responsabilidade Social, mantido pelo Setor de Recursos Humanos, porém sem interesse imediato de uma certificação. A gerência do Sistema de Gestão da Qualidade é de responsabilidade do Diretor Técnico também responsável por todas as operações industriais da empresa, englobando o planejamento e controle da produção, projeto e desenvolvimento de produtos, suprimentos e gestão de estoque e atividades de controle da qualidade.

Segundo o Diretor Técnico, o monitoramento formal da satisfação de cliente foi implementado antes mesmo da primeira certificação, em 1997 e já passou por várias melhorias. A partir de 2001, a empresa passou a utilizar um modelo desenvolvido pela matriz e utilizado por todas as filiais, espalhadas pela Europa, América do Sul e México. Como todas as unidades utilizam o mesmo modelo, a empresa pode realizar comparações entre unidades, sendo o índice de satisfação um indicador de desempenho organizacional.

A empresa utiliza um software de pesquisa, baseado em um sítio da Internet. Por ocasião da primeira venda, o Gerente de Marketing realiza uma visita ao cliente e, juntamente com este, define os seguintes elementos da pesquisa:

a) Profissionais a serem pesquisados;

b) Frequiência da pesquisa; 
c) Questionários de pesquisa específicos para cada profissional pesquisado;

d) Pesos a serem atribuídos a cada questionário;

e) Escala de resposta, sempre numérica, mas, de acordo com as preferências do cliente.

Todos os dados são posteriormente cadastrados no sistema e é liberada uma senha para cada profissional do cliente.

A empresa considera etapa de validação o primeiro mês de pesquisa, onde é solicitado a cada profissional pesquisado, responder a pesquisa por cinco dias consecutivos, verificando se há variação nas respostas; nesta fase ainda existe um campo nos questionários de pesquisa para que cliente pesquisado possa solicitar inclusões, exclusões ou alterações na forma das perguntas.

Após este período de validação, o questionário é fixo e permanece inalterado por um período mínimo de um ano.

Independente da escala utilizada para coletar as respostas, todas as notas atribuídas por todos os clientes são normalizadas em uma escala de zero a cem, para fins de comparação entre clientes e entre unidades da organização.

Em função dos dados cadastrados, o sistema gera $e$-mails para os clientes cadastrados convidando-os a responder o questionário de pesquisa nas datas acordadas. $\mathrm{O}$ autor 
pode constatar que a frequiência varia de semanal a trimestral, com grande predominância para a freqüência mensal.

As respostas aos questionários de pesquisa são fornecidas diretamente no sitio da Internet da empresa e abastecem um banco de dados que realiza algumas funções estatísticas básicas como cálculo de médias e desvio-padrão.

O Diretor Técnico monitora semanalmente os índices de satisfação através do próprio sistema que fornece os seguintes dados, todos em formato de um painel, similar aos utilizados em softwares de Balanced Scorecard.

a) Índice Geral de Satisfação de Cliente: Índice que fornece a média de todos os clientes na semana; o sistema sempre calcula esta média com as informações mais recentes; assim, para os casos de pesquisas trimestrais, o sistema repete os mesmos valores até que nova pesquisa seja respondida;

b) Evolução do Índice Geral: para esta função, define-se o período de avaliação e o intervalo desejado (semanal, mensal, trimestral ou anual) e o sistema fornece um gráfico de linha, permitindo observar a evolução;

c) Índice por cliente: similar ao Índice Geral de Satisfação, mas para um cliente específico;

d) Evolução do Índice de cada cliente: também similar ao item b acima, específico para cada cliente;

e) Índices Individuais de cada questionário do cliente e evolução dos mesmos. 
O Sistema ainda permite que todas as filiais tenham conhecimento dos Índices das demais. Desta forma, segundo o Diretor Técnico, é possível compartilhar eventuais soluções que possam contribuir para melhorar os Índices de Satisfação.

A empresa ainda estabeleceu um Índice mínimo de 90 para a média do cliente e de 80 para cada questionário específico e sempre que estes índices não são atingidos, é feito um contato com o cliente e eventualmente ações são tomadas.

\subsubsection{Empresa "E"}

A empresa "E" é uma empresa de engenharia e construção industrial. Atua na construção, ampliação e reforma de galpões industriais. Está situada na cidade de Piracicaba, estado de São Paulo e possui cerca de 200 funcionários. A empresa não quis declarar o seu faturamento. A empresa é certificada ISO 9001-2000 no ano de 2003 e está implantando um Sistema de Gestão Ambiental com previsão de certificação em meados de 2007. A gerência do Sistema de Gestão da Qualidade é de responsabilidade do Gerente da Qualidade.

O monitoramento formal da satisfação do cliente foi implementado para atender aos requisitos da norma ISO 9001-2000. 
A empresa tem, em média, uma carteira de oito clientes simultaneamente e seus projetos variam de três meses a dois anos, dependendo do porte e complexidade das obras que executa.

A empresa adotou a pesquisa de satisfação como método para monitoramento da satisfação do cliente. Para tanto, criou quatro questionários de pesquisa, específicos para cada fase do empreendimento, a saber:

a) Questionário para a fase de comercialização;

b) Questionário para a fase de projeto;

c) Questionário para a fase de obra;

d) Questionário para a fase de entrega.

Os questionários foram elaborados pelo Gerente da Qualidade com a participação dos Gerentes Comercial, de Engenharia, Suprimentos e de Obras. O questionário de satisfação para a fase de comercialização é aplicado mesmo quando a proposta não é aprovada. Segundo o Gerente da Qualidade é uma forma de avaliar os motivos de perda de cliente.

Para todas as fases do monitoramento, a pesquisa é aplicada pessoalmente pelo Gerente da Qualidade que define com as demais gerências envolvidas em cada etapa do processo quais são os representantes do cliente que devem ser ouvidos e em que momento do ciclo do empreendimento; assim, é realizado um planejamento de pesquisa tão logo o contrato seja fechado com o cliente, utilizando-se como referência 
o cronograma do contrato. Dependendo deste cronograma, os questionários para a fase de projeto e obras podem ser aplicados mais de uma vez e eventualmente alterados para captar particularidades do contrato. Segundo o Gerente da Qualidade isto se faz necessário devido à natureza dos serviços executados; uma obra totalmente nova difere em muito de uma reforma ou ampliação, onde em muitos casos, a empresa-cliente está operando normalmente e neste caso, o relacionamento é muito mais complexo.

Os questionários são preparados para serem respondidos em uma escala de zero a cinco. Para notas inferiores a quatro, é solicitado ao cliente informar as razões que o levaram a atribuir tal nota e, caso o mesmo deseje, pode também fazer sugestões de melhoria.

O método trata cada cliente individualmente, não existindo um índice médio de satisfação de todos os clientes. Para formar o Índice do Cliente, a cada questionário é atribuída uma nota máxima de 100 pontos e a medida em que pesquisas para as demais etapas do contrato são realizadas, são calculadas médias entre os questionários aplicados.

Todas as pesquisas executadas são levadas à reunião gerencial que ocorre mensalmente para avaliação de indicadores de desempenho do contrato, sendo a satisfação do cliente um dos indicadores avaliados. 


\subsubsection{Análise dos casos descritos}

A empresa "A" possui um bom sistema de monitoramento de satisfação do cliente, destacando-se o fato de designar uma equipe multidisciplinar para a preparação dos questionários de pesquisa, a consideração de informações provenientes de reclamações e outras informações de clientes e, principalmente, o foco nos processos, encaminhando a pesquisa para os profissionais do cliente que realmente experimentam a satisfação com o relacionamento cliente-fornecedor. Importante destacar também a forma de amostragem utilizada que permite que todos os clientes ativos sejam pesquisados ao menos uma vez ao ano e a inclusão de clientes que, por qualquer razão, explicitaram suas insatisfações através de reclamações, na relação de clientes a ser pesquisado no ciclo seguinte.

Como fato negativo, a não realização de uma validação estatística não permite dimensionar o erro da pesquisa, podendo assim comprometer seus resultados e posterior análise e tomada de ações.

A empresa "B" adotou métodos similares à empresa "A", elaborando vários questionários de pesquisa focando o tipo de serviço prestado. A freqüência de monitoramento, declarada trimestral, na verdade é anual, visto que cada tipo de serviço é pesquisado uma vez ao ano e eventuais ações somente terão seu impacto avaliado no ano seguinte. Por outro lado, o fato de a empresa pesquisar a satisfação dentre aqueles clientes que se utilizaram do serviço pesquisado no trimestre anterior é uma 
abordagem adequada, visto que este período cobre, em sua grande maioria, o tempo em que o cliente experimenta os serviços (normalmente consultas e internações ou mesmo tratamentos ambulatoriais exigem retornos, fazendo com que a experiência de consumo dos serviços se prolongue e proporcione ao cliente uma idéia mais clara sobre a qualidade dos serviços e sua satisfação ou insatisfação). A amostragem e sua validação estatística pode ser considerada adequada por seguir preceitos universais de técnicas estatísticas utilizadas por empresas de pesquisa de mercado.

Interessante observar que, apesar da empresa se utilizar de um modelo explícito do paradigma da desconfirmação ( SERVQUAL), onde o cliente é solicitado a informar o que ele espera de um determinado serviço e sua percepção sobre o serviço efetivamente prestado, e a satisfação ou insatisfação obtida da diferença entre as duas variáveis, tal conceito não é claramente entendido pela organização. Questionado, o Representante da Direção apenas informou que o modelo foi proposto pela consultoria e que os resultados têm proporcionado uma visão clara sobre o nível de satisfação dos usuários e, por conseqüência, das empresas-cliente. Também positivo é o fato do resultado da pesquisa ser apresentada ao representante do cliente.

O método adotado pela empresa " $\mathrm{C}$ ", aparentemente utilizado pela maioria das empresas com certificado ISO 9001-2000, nos parece inadequado por se constituir em um questionário muito longo e ser encaminhado somente à área de qualidade do cliente, além da dificuldade posterior para a compilação de resultados. Também na empresa "C" não há qualquer indício de uma validação do instrumento de pesquisa, e 
nem mesmo a compreensão sobre a necessidade de tal procedimento para tornar os resultados utilizáveis.

Dentre as empresas visitadas, a empresa " $D$ " nos parece a que desenvolveu o melhor modelo. Ao visitar o cliente e, juntamente com ele, definir os parâmetros de monitoramento de satisfação, fica explicitada a voz do cliente, desde o primeiro momento do relacionamento. A validação executada cobre os aspectos de "validade" do instrumento, de acordo com Hayes (2001), ou seja, o questionário de pesquisa é avaliado quanto a sua capacidade de medir aquilo para o qual foi criado. A rotina de pesquisa facilita a resposta do cliente, evitando demora no preenchimento dos questionários, visto que toda a operação é realizada em ambiente de Internet, assim como a compilação de resultados de diferentes clientes. Também é muito positiva a freqüência acordada junto aos clientes, variando de semanal a mensal, de forma a captar a satisfação no exato momento em que ela ocorre. O software permite a geração de vários indicadores, monitorados pelo Diretor Técnico, profissional com autoridade para implementar ações de forma rápida e, em função da frequiência, é possível visualizar os efeitos das ações em tempo hábil para eventuais alterações.

A empresa E também possuem pontos positivos e negativos em seu método. Por ter poucos clientes, é capaz de monitorar a satisfação de $100 \%$ deles, não havendo necessidade de se recorrer a métodos estatísticos. Com a preocupação de mensurar a satisfação ao longo de todo o contrato, a empresa é capaz de promover alterações caso 
o índice do cliente esteja abaixo das expectativas (nota abaixo de quatro para cada item do questionário).

Com exceção da empresa $\mathrm{E}$, todas as demais estabeleceram índices médios de satisfação e metas para os mesmos, parecendo ser uma prática usual, evidenciada também na pesquisa quantitativa. 


\section{CONCLUSÃO}

\subsection{CONCLUSÕES}

A pesquisa quantitativa aliada ao estudo de múltiplos casos (análise qualitativa) demonstrou que as empresas que operam no contexto B2B e têm certificado ISO 9000 no estado de São Paulo realizam esforços no sentido de monitorar a satisfação de seus clientes, sendo a pesquisa de satisfação o principal método utilizado, a qual, em alguns casos, é aliada a outras ferramentas, como o tratamento às reclamações.

Alguns fatores, considerados importantes quando se aborda o uso de instrumentos de medição, são ignorados, principalmente aqueles referentes à validação dos questionários de pesquisa. De acordo com Hayes (2001), todo instrumento de pesquisa deve ser validado quanto a sua confiabilidade, definida pelo autor como o grau com que as medições estão isentas de variâncias de erros aleatórios, e quanto a sua validade, ou seja, o grau com que a evidência corrobora as conclusões tiradas a partir dos valores derivados das medições (o grau com que a escala mede aquilo para o qual foi criada para medir).

Outro fator de relevância é a freqüência com que as medições são realizadas. O estudo quantitativo evidenciou que 316 empresas realizam suas pesquisas de satisfação em intervalos iguais ou maiores que seis meses, constituindo outro ponto negativo dos métodos adotados. De acordo com Giese e Cote (2000), a satisfação tem duração e 
deve ser captada, preferencialmente, no momento em que ela é experimentada. É razoável supor que seis meses é um período extenso demais, comprometendo assim, a confiabilidade dos resultados.

Como resultados positivos destacam-se:

a) O envolvimento de vários setores das empresas na preparação dos questionários de pesquisa. Tal prática pode ser considerada positiva, pois contribui para a validade do instrumento, já que aumenta a probabilidade de inclusão de todas as dimensões que afetam a satisfação;

b) A inclusão de diversos aspectos em seus questionários, não se limitando a perguntas relacionadas à qualidade do produto ou serviço, consideradas também positivas pelas mesmas razões expostas no item (a) acima;

c) O encaminhamento de questionários de pesquisas a diversos setores do cliente, não se limitando à área da qualidade ou ao comprador. Esta prática contribui para melhorar a confiabilidade do instrumento, pois as respostas daqueles que efetivamente experimentaram a satisfação provavelmente estarão menos sujeitas a erros se comparadas a uma resposta de um único representante do cliente;

d) A avaliação conjunta dos questionários respondidos por dois ou mais setores das empresas pesquisadas, indicando que as empresas consideram a atividade relevante e despendem recursos para sua avaliação;

e) O estabelecimento de indicadores de satisfação com metas para os mesmos;

f) O esforço no sentido de se estabelecer melhorias para o método utilizado. 
O estudo de múltiplos casos pesquisou cinco organizações de diversos ramos de atividade, e procurou-se aprofundar nas questões de pesquisa quantitativa, verificandose que as empresas pesquisadas realizam um grande esforço no sentido de obter informações sobre a satisfação de seus clientes e fazem uso das mesmas para o estabelecimento de ações estratégicas no sentido de manter e melhorar os níveis de satisfação. No entanto, não se pôde verificar em nenhuma das empresas visitadas qualquer tentativa de se estabelecer correlações entre os níveis de satisfação obtidos com outros indicadores de desempenho, aparentando que a medição da satisfação é um processo-fim e não um meio para se obter melhores resultados organizacionais.

Bolton, Lemon e Verhoef (2004) afirmam que as empresas monitoram a satisfação de seus clientes porque acreditam que a satisfação leva a fidelização. Clientes satisfeitos retornam e realizam novas compras, e isto é fundamental para a sobrevivência de empresas, principalmente no mercado $\mathrm{B} 2 \mathrm{~B}$, onde o número de clientes é limitado e as transações entre eles normalmente são de valor significativo.

Partindo da revisão da literatura e insights obtidos através da pesquisa de campo, podese sugerir que o monitoramento de satisfação deve contemplar:

a) Determinação de quais os clientes que a empresa tem interesse em monitorar Para empresas que possuem uma carteira muito heterogênea de clientes, torna-se complexo satisfazer a todos. Uma abordagem baseada em "Lifetime Value" (LTV Valor ao longo da vida) pode ser utilizada para classificar os clientes e concentrar 
esforços naqueles que proporcionarão maior rentabilidade no futuro. Para esses casos, a amostragem aleatória pode não ser a melhor solução. Já para uma base de clientes homogênea, a amostragem aleatória pode fornecer bons resultados a um custo baixo.

b) Determinação de quais fatores geram a satisfação do cliente

A técnica do incidente crítico utilizada por Hayes (2001) demonstra ser adequada em virtude de se utilizar dados provenientes dos próprios clientes. Perguntar ao cliente o que o levou a ficar satisfeito ou insatisfeito é o caminho mais curto para se chegar aos determinantes da satisfação. Lembrando o enunciado de Schellase, Hardock e Ohlwein (1999), que a satisfação de uma empresa é resultado de um processo complexo de informações e que vários atores contribuem para formar esta satisfação, torna-se razoável sugerir que a técnica do incidente crítico seja aplicada junto aos funcionários das empresas clientes que, de alguma forma, mantenham alguma interface com a organização. Assim, o modelo deve determinar quais são estas interfaces e quem são os ocupantes dos cargos que vão contribuir para o resultado final. Esta etapa do modelo deve ser encerrada com a criação do instrumento de pesquisa, o qual deve ser validado antes de sua implementação.

c) Determinação do momento em que a satisfação deve ser captada

De acordo com Giese e Cote (2000), a satisfação tem duração e, portanto, deve ser mensurada enquanto ela ocorre. Portanto, o modelo deve se preocupar em mensurar a satisfação nas diversas fases do relacionamento e, se necessário, de forma independente. Assim, por exemplo, em um contrato de longa duração, as fases pré- 
compra, compra e pós-compra podem e devem ser tratadas separadamente e não apenas a mensuração de um nível geral de satisfação ao final do contrato.

d) Análise de resultados

O modelo para monitoramento de satisfação deve prever o que fazer com os resultados obtidos da mensuração. Assim, deve-se definir quais funções dentro da organização devem analisar tais resultados e como devem ser monitoradas as ações tomadas em decorrência desta análise. Deve ainda estabelecer correlações com os demais indicadores de desempenho da organização no sentido de se conhecer como os níveis de satisfação do cliente comprometem os resultados organizacionais.

Por fim, dada a dinâmica da satisfação, o modelo deve prever a necessidade de revisão em sua estrutura para se manter atualizado ao longo do tempo. O modelo proposto é esquematizado na figura 29. 

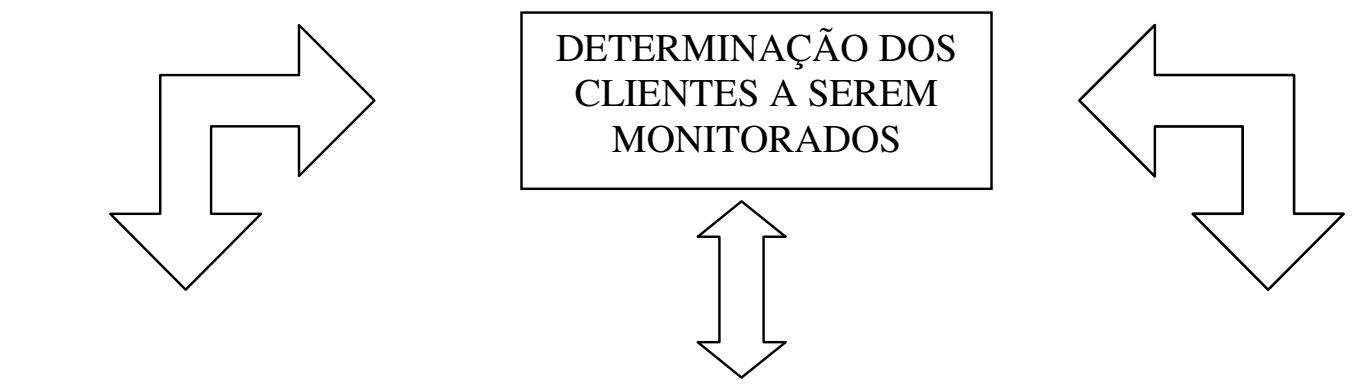

\begin{tabular}{|c|}
\hline MOMENTO EM QUE \\
A SATISFAÇÃO \\
DEVE SER \\
CAPTADA \\
\hline
\end{tabular}
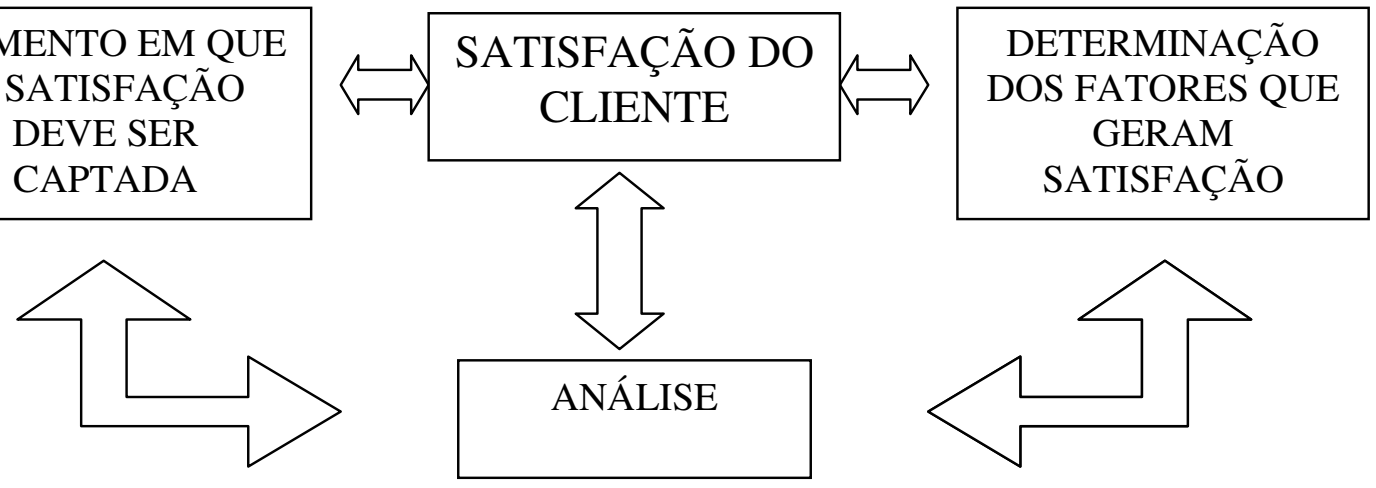

Figura 29 - Modelo para monitoramento de satisfação de cliente em contexto B2B Fonte: Autor

\subsection{LIMITAÇÕES E RECOMENDAÇÕES PARA FUTURAS PESQUISAS}

A atual pesquisa abordou as empresas certificadas no Estado de São Paulo que operam em contexto B2B e que possuem certificado ISO 9000. O modelo proposto deverá ser testado em algumas empresas e seus resultados comparados com os apresentados pelos métodos atualmente em uso nessas empresas. 


\section{REFERÊNCIAS}

ADAMS, J.S. Towards an Understanding of Inequit. Journal of Abnormal and Social Psycology, p.422-436, 1963.

ANDERSON, E. W.; FORNELL, C. Foundations of American Customer Satisfaction Index. Total Quality Management, v.11, n.7, p.869-880, 2000.

ANDERSON,E.W; SULLIVAN,M.W. The Antecedents and Consequences of Customer Satisfaction for Firms. Marketing Science, p.25-43, 1993.

BABBIE, E. Métodos de Pesquisa de Survey. Belo Horizonte: Editora UFMG, 1999.

BEARDEN, W.D; TEEL. J.E. Selected Determinants of Consumer Satisfaction and Complaint Reports. Journal of Marketing Research, v.20, p.21-28, 1983.

BOLTON, R. N.; DREW, J.H. A Multistage Model of Customers Assesment of Service Quality and Value. Journal of Consumer Research, n.30 p.7-27, 1991

BOLTON, R.N.; LEMON, K.N.;VERHOEF, P.C. The Theoretical Underpinnings of Customer Asset Management: A Framework and Propositions for Future Research. Journal of the Academy of Marketing Research, v.32, n.3, p.271-292, 2004.

BRUHN, M.; GRUND, A. G. Theory, Development and Implementation of National Customer Satisfaction Indices: The Swiss Index of Customer Satisfaction (SWICS). Total Quality Management, v.11, n.7, p.117-128, 2000.

BRYMAN, A. Research Methods and Organization Studies. London: Routledge, 1995.

CADOTTE, E.R.; WOODRUFF, R.B.; JENKINS,R.L. Expectations and Norms in Models of Consumer Satisfaction. Journal of Marketing Research, v.24, p.305-314, 1987.

CARDOZO, R. N. An Experimental Study of Consumer Effort, Expectation and Satisfaction. Journal of Marketing Research, v.2, p.244-249, 1965.

CHURCHILL,G.A.; SUPRENANT, C. An investigation into the determinants of customer satisfaction. Journal of Marketing Research, v.19, p.491-504, 1982.

COOPER, R.D.; SCHINDLER, P.S. Métodos de Pesquisa em Administração. São Paulo: Bookman, 2003.

CRONIN, J.J; TAYLOR S.A. Measuring Service Quality: A Reexamination and Extension Journal of marketing, p.55-68, 1992. 
DAY, R.L. Modeling Choices Among Alternative Response to Dissatisfaction. Advances in Consumer Researches, p.496-499, 1984.

DEMING, W. E. Qualidade: a revolução da Administração. Rio de Janeiro: MarquesSaraiva, 1990.

ERTO, P.; VANACORE,A. A Probabilistic Approach to Measure Service Quality. Total Quality Management, v.13, n.2, p. 165-172, 2002

FEIGENBAUM,A.V. Controle da Qualidade Total-Vol. III- Métodos estatísticos aplicados à Qualidade. São Paulo: Makron e Mcgray-Hill, 1991.

FILIPPINI, R. Operations management research: some reflections on evolutions, models and empirical studies in O.M. International Journal of Operation \& Production Management. New Yorkshire, v.17, n.7, 1997.

FORNELL, C. A national Customer Satisfaction Barometer: The Swedish Experience. Journal of Marketing, v.56, p.6-21, 1992.

FORZA, C.: Survey research in operations management: a process-based perspective. International Journal of Operations \& Production Management; New Yorkshire, v.22, n.2, 2002.

FUNDIN, A. P.; BERGMAN, B. S. Exploring the Customer Feedback Process. Measuring Business Excellence. Bradford, v. 7, n. 2, p. 55-66, 2003.

GARVIN, D. Gerenciando a qualidade: a visão estratégica e competitiva. Rio de Janeiro:Qualitymark, 1992.

GHAURI, P.: GRONHAUG, K, KRISTIANLUND, J. Research method in business studies - a pratical guide. New Jersey: Prentice - Hall, 1995.

GIESI, J. L.; COTE, J.A. Defining Consumer Satisfaction. Academy of Marketing Science, v. 2000, n.1, p.1-27, 2000.

GRONROOS, C. Strategic Managementand Marketing in the Service Sector.Swedish School of Economics and Business Administration, 1982.

GURAU. C. How to Calculate the Value of a Customer: Measuring Customer Satisfaction.Journal of Targeting, Measurement and Analsysis for Marketing, p.203220, 2002.

HACKL, P.; WESTLUND, A. H. On Structural equation Modelling for Customer Satisfaction Measurement. Total Quality Management, v.11, n.4-6, p.821-827, 2000. 
HARRINGTON, J. Aperfeiçoando Processos Empresariais. Makron Books, São Paulo, 1993.

HAYES, B. E. Medindo a satisfação do cliente- Desenvolvimento e uso de questionários Rio de Janeiro: Qualitymark, 2001.

HOLLBROOK, M.B. - Situation-especific Ideal Points and Usage of Multiple Dissimilar Brands. Research in Marketing, v.7, p.93-112, 1984.

HOWARD, J.A.; SHETH, J.N. The Theory of Buyer Behavior. New York: Wiley Marketing Series, 1969.

HRONEC, S. Sinais vitais: usando medidas do desempenho da qualidade. São Paulo: Makron Books, 1993.

ISHIKAWA, K. Controle da Qualidade Total à maneira japonesa. Rio de Janeiro: Campus, 1993.

JURAN, J.M. Juran na liderança pela Qualidade. São Paulo: Pioneira, 1990.

JURAN, J. M. Planejando para a Qualidade - São Paulo Pioneira, 1992.

KAPLAN, R. S.; NORTON, D. P. Translating strategy into action: the balanced scorecard. Harvard Business School Press, 1996.

KOTLER, P. Administração de marketing: análise, planejamento, implementação e controle. São Paulo: Atlas, 1998.

LA BARBERA, P.; MAZURSKY, D. A Longitudinal Assessment of Consumer Satisfaction, Dissatisfaction. The Dynamic Aspect of the Cognitive Process. Journal of Marketing Research, v.20, p.393-404, 1983.

LAMBERT, R. Customer Satiscation and Future Financial Performance: Discussion of are Nonfinancial Measures Leading Indicators of Financial Performance? An Analysis of Costumer Satisfaction. Journal of Accounting Research, v.36, Supplement p.37-46, 1998.

LATOUR S. A.; PEAT N. Conceptual and Methodological Issues of Consumer Satisfaction Research. Advances in Consumer Research, v.6, p.431-437, 1979.

LIECHTY, M.; CHURCHILL G. A. Conceptual Insights and Consumer Satisfactions with Services. American Marketing Association, p.509-515, 1979.

MALHOTRA, N.K. Pesquisa de Marketing: Uma Orientação Aplicada. 3.ed. Rio Grande do Sul: Bookman, 2001. 
MILlER. J. A. Studyng Satisfaction, Modifying Models, Eliciting Expectations, Posing Problems and Making Meaningful Measurements. Marketing Sciences Institute, p.72-91, 1977.

NAKANO, D.N, FLEURY, A.C.C. Métodos de Pesquisa na Engenharia de Produção in Encontro Nacional de Engenharia de Produção, Piracicaba, 1996.

NAORI, B.; SALIMI, M.H. A Decision-support System for Business-to-business Marketing. The Journal of Business \& Industrial Marketing, v.20, n.415, p.226-236, 2005.

OLIVER. R. L. A Theoretical Reinterpretation of Expectation and Disconfirmation Effects of Post-Exposure Product Avaluations: Experience in the Field. Consumer Satisfaction, Dissatisfaction and Complaining Behavior, p. 480-486, 1977.

OLIVER. R. L. A Cognitive Model of the Antecedents and Consequences of Satisfaction Decision. Journal of Marketing Research, v.17, p.460-469, 1980.

OLIVER R. L. Measurements and Evaluations of Satisfaction Process in Retail Settings. Journal of Retailing, v.57, p. 25-48, 1981.

OLIVER, R.; SWAN, I. Equity and Disconfirmation Perceptions as Influences on Merchant and Product Satisfaction. Journal of Consumer Research, v.16, p.372-383, 1989.

PARASURAMAN, A.; ZEITHAML, V. BERRY, L.L. A Conceptual Model of Service Quality and Its Implications for Future Research. Journal of Marketing, v.49, p.41-50, 1985.

PARASURAMAN, A.; ZEITHAML, V. BERRY, L.L. SERVQUAL: A multiple-item Scale for Measuring Consumer Perceptions of Service Quality. Journal of Retaling, v.64, n.1, p.12-40, 1988.

PINTO, S.H.B. Tendências dos Programas de Melhoria da Qualidade: Um Survey em Empresas de Grande Porte no Brasil: tese, Escola Politécnica USP, São Paulo, 2005.

PRIETO, V. C.; CARVALHO, M. M. Gestão do relacionamento com o cliente em mercados business to business. Revista Produção online, v.5, n.1, 2005.

ROTANDARO, R. G. Defining the customer's expectations in e-business. Industrial Management \& Data Systems, v.102, n.9, p.477-482, 2002.

RUMMLER, G A.; BRACHE, Al P. (1994). Melhores Desempenhos das Empresas, São Paulo: Makron Books. 
SCHELLASE,R; HARDOCK,P.; OHLWEIN,M. Customer satisfaction in business-tobusiness marketing: the case of retail organizatios and their suppliers. Journal of Business \& Industrial Marketing, v.14, n.5, p. 416-432, 1999.

SINK,D.S.; TUTTLE,T.C. Planejamento e Medição para a performance. Qualitymark, Rio de Janeiro, 1993.

THIOLENT, M. Metodologia da Pesquisa Ação. 6. ed. Editora Cortez, São Paulo, 1994.

WALKER, L.J.H.; NEELEY, S.E. Customer Relationship Building on the Internet in B2B Marketing: A Proposed Typology. Journal of Marketing Theory and Practice, p.19-34, 2004.

WESTBROOK, R.; REILLY, M. Value-percept Disparity. An Alternative to Disconfirmation of Expectation Theory of Consumer Satisfaction. Advances in Consumer Research, p.256-261, 1983.

WOODRUFF, R.B.; CADOTTE, E.R.; JENKINS.R.L. Modeling Consumer Satisfaction Process Using Experience-Based Norms. Journal of Marketing Research, v.20, p.296-304, 1983.

YI, Y. A Critical Review of Consumer Satisfaction. American Marketing Association. P. 68-123, 1990.

YIN, R.K. Estudo de Caso - Planejamento e Métodos. São Paulo: Bookman, 2004. 


\section{BIBLIOGRAFIA COMPLEMENTAR}

ALBRECHT, K. Revolução nos Serviços - Livraria Pioneira Editora, 1994.

AVERY, C.; RESNICK P; ZECKAUSER, R. The Marketing for Evaluations The American Economic Review, v.89, n.3, Jun 1999.

BARSKY,. J.; NASH, L. Customer Satisfaction: Applyng Concepts to Industry-wide Measures . Cornell University, v.44, n.6, Oct/Dec 2003.

BREWER, K. Implementing ISO 9001-2000 — Prentice hall, 2001.

CLARKE. G. Confirming Satisfaction as an attitude within the Service-Buying Process. Journal of Consumer Behavior, p.111-123, 2001.

CRESWELL, J.W. Research Design: qualitative \& quantitative approaches. Resumo feito por Elisabeth Adriana Dudziack. London: Sage, 1994.

DANAHER. P.; MATTSSON, J. Customer Satisfaction during the Service Delivery Process. European Journal of Marketing Bradford, v.28, n.5, 1994.

EDVARDSSON, B.; JOHNSON, M.D.; GUSTAFSSON, A.: STRANDVIK,T. The Effects of Satisfaction and Loyalty on Profits and Growth: Products versus Services. Total Quality Management, v.11, n.7, p.917-927, 2000.

ELEUTÉRIO, S.A; SOUZA, M.C. Qualidade na prestação de serviços: uma avaliação com clientes internos- Caderno de Pesquisa em Administração FEA-USP, São Paulo, v.9, n.3, Jul/Set 2002

FARMER, J. H. A Conceptual Model of Service Quality International Journal of Operations \& Production Management, v.8, n.6, p.19-29, 1987.

GIANESI, I. G. N.; CORRÊA, H. L. Administração estratégica de serviços : operações para a satisfação do cliente. São Paulo: Atlas, 1996.

GOLD, M.; WOOLDRIDGE, J. Surveying Consumer Satisfaction to Assess Managedcare Quality: Current Practices. Health Care Financing Review, v.16, n.4, 1995.

HACKL, P.; SCARITZER, D. ZUBA, R. Customer Satisfaction in the Austrian Food Retail Market. Total Quality Management, v.11, n.7, Sep. 2000.

HOGARTH. J. M.; ENGLISH. M.; SHARMA. M. Consumer Complaints and Third Parties: Determinants of Consumer Satisfaction with Complaint Resolution Efforts. Journal of Consumer Satisfaction, Dissatisfaction and Complaining Behavior, 2001.

MATTAR, F. N. Pesquisa de Marketing. São Paulo: Atlas, 1996. 
MATTSSON, J. A Service Quality Model Based on an Ideal Value Standard. International Journal of Service Industry Management Bradford, v.3, n.3, 1992.

MELLO, C H. P. ISO 9001-2000. São Paulo:Atlas, 2002.

NAMASIVAYAM, K. The Consumer as Transient Employee. Consumer Satisfaction trhough the Lens of Job-perfomance Models Journal of Service Industry Management Bradford, v.14, n.3, 2003.

RYZIN, G.G.: MUZZIO, D.; IMMERWARHR.S.; GULICK, L.; MATINEZ, E. Drivers and Consequences of Citizens Satisfaction: An application of the American Consumer Satisfaction Index Model to New York Cit. Public Administration Review. Washington, v.64, n.3, May/Jun 2004.

SANTOS. J.; BOOTE J. A Theoretical Exploration and Model of Consumer Expectation, Post-purchase Affective States and Affective Behavior Journal of Consumer Behavior. London, v.3, n. 2, Dec. 2003

SWADDLING, D. C.; MILLER, C. Don't Measure Customer Satisfaction. Quality Progress, p.62-68, 2002.

TSE, D.; WILTON P. Models of Consumer Satisfaction Formation: An Extension Journal of Marketing Research, v.25, p. 204-212, 1998.

WIRTZ, J.; BATESON, J.E.G. Introducing Uncertain Performance Expectations in Satisfaction Models for Services International Journal of Service Industry Management. Bradford, v.10, n.1, 1999.

WIRTZ, J. An Examination of the Quality and Context-specific Applicability of Commonly used Customer Satisfaction Measures. Journal of Service Research, v.5, n.4, May 2003.

YANG, C.C. Establishment and Applications of the Integrated Model of Service Quality Measurement Managing Service Quality Bedford, v.13, n.4, 2003.

ZEITHAML, V.A.; PARASURAMAN, A; BERRY L.L. Delivering Quality Service Free Press, 1990 


\section{ANEXO - INSTRUMENTO DE PESQUISA SURVEY}

Convidamos você a participar de nossa pesquisa a respeito de satisfação de cliente. Esta pesquisa é parte de um trabalho de mestrado do Departamento de Engenharia de Produção da Escola Politécnica da Universidade de São Paulo que visa identificar como as empresas com certificado ISO 9001-2000 estão atendendo o requisito normativo de monitoramento de Satisfação de Cliente. Um pré-teste do questionário de pesquisa indicou que não se demora mais que 8 minutos para responder as questões

propostas. A todos que responderem disponibilizaremos, ao final dos trabalhos, os resultados e conclusões os quais, eventualmente, podem ser utilizados como benchmark por sua empresa. Finalmente, assumimos o compromisso de não divulgar quaisquer informações sobre sua empresa, a menos que seja de seu interesse e que seja formalmente autorizado. Certos de sua colaboração, agradecemos antecipadamente.

Mestrando Marcos Antonio de Oliveira

Orientador: Prof. Dr. José Joaquim do Amaral Ferreira 


\section{INFORMAÇÕES GERAIS DA EMPRESA}
a) Razão social da empresa
b) Endereço.
c) Pessoa de contato
d) Telefone
e) E-mail
f) Certificação
( ) ISO 9001-2000
( ) Outro
g) Certificadora.
h) Sistema de negócio
( ) B2B
( ) $\mathrm{B} 2 \mathrm{C}$
( ) Ambos

\section{QUESTÕES}

1) A empresa realiza um monitoramento de satisfação de cliente?
( ) $\operatorname{Sim}$
( ) Não

2) É utilizado algum modelo existente em literatura para preparação do questionário?

( ) Sim, favor especificar.

( ) Não

3) Qual departamento/setor da empresa é responsável pelo monitoramento da satisfação dos clientes?

( ) Qualidade

( ) Marketing

( ) Vendas

( ) Outro

4) Qual é o método utilizado?

( ) Pesquisa de satisfação

( ) Avaliação de reclamações

( ) Indicadores fornecidos pelos próprios clientes

( ) Outros indicadores de relacionamento (evolução de pedidos, evolução de número de reclamações, etc.) 
5) Com que freqüência é realizado o monitoramento de satisfação do cliente?

( ) A cada pedido/contrato

( ) Mensalmente

( ) Trimestralmente

( ) Semestralmente

( ) Anualmente

( ) Intervalos superiores a um ano

6) Como determina a amostra?

( ) Realiza pesquisa em $100 \%$ dos clientes ativos

( ) Utiliza critérios estatísticos

( ) Realiza pesquisa somente junto aos clientes mais importantes

( ) Outro

7) Qual o procedimento com relação a clientes que deixaram de comprar por um longo período?

( ) São incluídos na amostra

( ) Não são incluídos na amostra

8) Como são preparados os questionários de pesquisa?

( ) Perguntas definidas pela área de marketing

( ) Perguntas definidas pela área de vendas

( ) Perguntas definidas pela área de qualidade

( ) Perguntas preparadas em conjunto por 2 ou mais setores

( ) Outro

9) Na formulação das perguntas são considerados:

( ) Somente aspectos relacionados à qualidade do produto/serviço

( ) Somente aspectos relacionados ao atendimento pré-venda

( ) Somente aspectos relacionados ao atendimento pós-venda

( ) Todos os aspectos acima

10) É realizado algum tipo de teste para validar o questionário de pesquisa?

( ) Sim (especificar).

( ) Não

11) A quem a pesquisa é endereçada?

( ) Comprador

( ) Área da qualidade do cliente

( ) Usuário do produto/serviço

( ) Outro 
12) Quem avalia os resultados da pesquisa?

( ) Qualidade

( ) Marketing

( ) Vendas

( ) Produção

( ) Diretoria

( ) Outro

13) Como são apresentados os resultados da pesquisa para análise?

( ) Relatórios consolidados

( ) Avaliado um a um cada questionário respondido, sem comparar com outros

( ) Outro

14) A empresa estabeleceu um "Índice de Satisfação"? (Se sim, favor informar como o mesmo é determinado)

( ) $\operatorname{Sim}$

( ) Não

15) Caso a empresa tenha estabelecido um Índice, existe alguma meta para o mesmo? (Se sim, favor informar como o mesmo é determinado)

( ) Sim.

( ) Não

16) São tomadas ações em função dos resultados da pesquisa?

( ) $\mathrm{Sim}$

( ) Às vezes

( )Nunca

17) Qual o retorno médio de questionário respondidos?

( ) Inferior a $10 \%$

( ) De 10 a $30 \%$

( ) De 30 a $60 \%$

( ) Superior a $60 \%$

18) Questionários enviados e não respondidos pelos clientes:

( ) São sempre ignorados

( ) Dependendo da importância do cliente, podem ou não ser ignorados

( ) É realizada uma pesquisa verbal para obter a percepção do cliente

( ) O cliente pesquisado é substituído por outro (na pesquisa) a fim de manter o número mínimo do tamanho da amostra

19) A empresa já implementou alguma melhoria no modelo de pesquisa?

( ) Sim, favor especificar

( ) Não 